\title{
WHO LET THE LAWYERS OUT?: RECONSTRUCTING THE ROLE OF THE CHIEF LEGAL OFFICER AND THE CORPORATE CLIENT IN A GLOBALIZING WORLD
}

\author{
Constance E. Bagley* \\ Mark Roellig** \\ Gianmarco Massameno*** \\ "If you aint cheating, you aint trying." \\ - Barclays Bank foreign exchange trader ${ }^{1}$
}

"Americans should never believe, even incorrectly, that one's criminal activity will go unpunished simply because it was committed on behalf of a corporation."

- Deputy Attorney General Sally Quillian Yates ${ }^{2}$

\begin{abstract}
* Constance E. Bagley is a Senior Research Scholar in Law at the Yale Law School and was previously Professor in the Practice of Law and Management at the Yale School of Management and Associate Professor of Business Administration at the Harvard Business School. The authors gratefully acknowledge the valuable assistance of Professor Boel Flodgren of Lund University in gathering and analyzing the data from Swedish general counsel in Part VI of this Article. They also thank Professor Gillian K. Hadfield of the University of Southern California Law School for her kind permission to use excerpts of her interviews with general counsel. In addition, they also thank Susan Schillaci for her excellent research assistance and Christoph A. Bagley for his graphics support.

** Mark Roellig is Executive Vice President and General Counsel of the Massachusetts General Life Insurance Company and previously served as General Counsel of Fisher Scientific International Inc., Storage Technology Corporation, and U S West. He is also an Adjunct Professor at Colorado Law, University of Colorado Boulder.

*** Gianmarco Massameno served as Process Development Administrator to Daimlerowned Mercedes-Benz USA addressing compliance issues. He was also the Learning Assessment Fellow to the Dean of the Harvard Graduate School of Arts \& Sciences.
\end{abstract}

1. James Titcomb, Barclays Handed Biggest Bank Fine in UK History Over 'Brazen' Currency Rigging, TELEGRAPH (May 20, 2015, 8:17PM BST), http://www.telegraph.co.uk/finance/newsbysector/banksandfinance/11619188/Barclayshanded-biggest-bank-fine-in-UK-history-over-brazen-currency-rigging.html [perma.cc/SW3P-98DW].

2. Sari Horwitz, Justice Dept. to Focus on Individuals in Cases of Corporate 
In the wake of the collapse of Lincoln Savings and Loan in 1989 and again after the implosion of Enron and WorldCom in 2001, Judge Stanley Sporkin famously asked, "Where were the lawyers?" Section 307 of the Sarbanes-Oxley Act of 2002 imposed new duties on in-house counsel to report up violations of law. Yet, we still had the LIBOR and foreignexchange rigging scandals, which had, by 2015, led to multi-billion dollar settlements and fired bank CEOs in England and Germany; rampant insider trading by hedge funds and corporate titans; the subprime mortgage crisis; the option backdating scandals; and massive recalls by automotive manufacturers Toyota, General Motors, and Volkswagen. We submit that legislation and regulatory action alone are, and will continue to be, insufficient to deter corporate misconduct of the sort we have experienced in the last two decades. As in-house counsel have become more entrepreneurial in both the United States and elsewhere, and as many business schools have failed to adequately prepare future managers to address the legal and ethical aspects of business, more attention must be focused on the internal forces within companies. In addition to addressing Judge Sporkin's question, we must ask, "Where were the managers?" In this Article, we provide new data on the role of in-house counsel in Sweden and assert that counsel and managers can be more effective drivers of both compliant corporate behavior and the creation of sustainable value if they work together as strategic partners, that is, when corporate managers are legally astute and are advised by strategically astute counsel.

INTRODUCTION

\section{A BRIEF HISTORY OF THE CHANGING ROLE OF GENERAL}

COUNSEL IN THE UNITED STATES

A. Period of Prestige: Post-Civil War through 1930s

B. Period of Decline: 1940s through Mid-1960s

C. Period of Renaissance: Mid-1960s through 1980s

D. Prestige at the Cost of Integrity?: 1980s to 2002

E. SOX Enforcement Era: 2002 through 2008

F. The Subprime Mortgage Crisis and Massive Product Recalls Land Counsel and their Clients Back in the Drink: 2008 to the Present.

II. LEGAL AND STRATEGIC ASTUTENESS ….....................................449

A. Value-Laden Attitudes ...........................................................450

B. Proactive Approach

Misconduct, WASH. Post (Sept. 10, 2015), https://www.washingtonpost.com/world/ national-security/justice-dept-to-focus-on-individuals-in-cases-of-corporate-misconduct/ 2015/09/10/c14b0ec0-57db-11e5-abe9-27d53f250b11_story.html [perma.cc/PC5W-JL8H]. 
C. Exercise of Informed Judgment

D. Context-Specific Knowledge of the Law and Business and the Application of Legal and Managerial Tools

E. Partnership of Legally Astute Managers with Strategically Astute Lawyers

III. General COUNSEl AS STRATEGIC PARTNER Not HiREd GUN

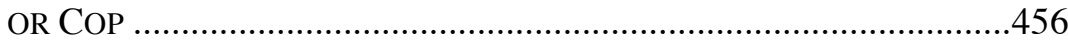

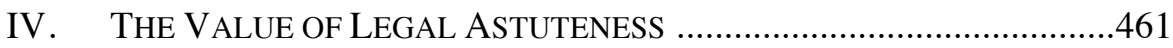

A. Using Contracts to Strengthen Relationships ..........................461

B. Enhancing, Leveraging, and Transforming the Value of Knowledge Assets and Other Firm Resources ........................465

C. Creating Options ................................................................467

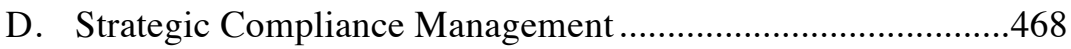

E. Shaping the Regulatory Environment.....................................471

V. TRAINING THE NEXT GENERATION OF LEGALly ASTUTE MANAGERS AND STRATEGICALLY ASTUTE LAWYERS......

VI. GLOBALIZATION AND THE CHANGING ROLE OF GENERAL

COUNSEL: NEW DATA, PREDICTIONS, AND PRESCRIPTIONS ...........488

A. The Anglo-American Nexus....

B. In-House Counsel in Sweden

C. The Application of Our Prescriptions Outside the United States.

VII. CONCLUSION

\section{INTRODUCTION}

In May 2015, Citicorp, JPMorgan Chase, Barclays, and the Royal Bank of Scotland agreed to plead guilty to conspiring to manipulate the price of U.S. dollars and euros exchanged in the foreign currency exchange spot market. ${ }^{3}$ They agreed to pay criminal fines in excess of $\$ 2.5$ billion. ${ }^{4}$ The Federal Reserve imposed an additional $\$ 1.6$ billion combined fine on those four banks, plus UBS, following its own foreign exchange investigation. ${ }^{5}$ Barclays settled related claims with other regulatory bodies for another $\$ 1.3$ billion. ${ }^{6}$ Reflecting the "brazen" nature of the scheme, one

3. Press Release, Dep't of Justice, Five Major Banks Agree to Parent-Level Guilty Pleas (May 20, 2015), http://www.justice.gov/opa/pr/five-major-banks-agree-parent-levelguilty-pleas [perma.cc/Y4ZB-DYBT].

4. $I d$.

5. $I d$.

6. Id. See also Lianna Brinded, The Fired Barclays CEO Had Two Nicknames Inside the Bank that Tell You Why He Was Forced Out, Bus. InSIDER (Jul. 8, 2015, 10:04 AM), http://uk.businessinsider.com/barclays-ceo-antony-jenkins-left-because-of-his-lack-of- 
Barclays' trader had written in an online chat room, "if you aint cheating, you aint trying."7

The foreign exchange fines are in addition to the more than $\$ 5$ billion imposed on Deutsche Bank, UBS, Royal Bank of Scotland, and other banks to settle charges of illegally rigging the London inter-bank lending rate ("LIBOR"), which is the lending benchmark for everything from student loans to commercial paper. Heads rolled: Juergen Fitschen and Anshu Jain, the co-chief executives of Deutsche Bank, Germany's largest lender, announced their resignations in June 2015, only weeks after Deutsche Bank agreed to pay a $\$ 2.5$ billion fine in connection with its role in the LIBOR scandal. ${ }^{9}$ This was in addition to the roughly $\$ 1.6$ billion the bank reserved in the first quarter of 2015 for related legal fees. ${ }^{10}$ Bob Diamond, the chief executive of Barclays, was an early casualty of the LIBOR affair-he was forced to resign in July 2012, after regulators fined the London-based bank $£ 290$ million (\$455 million) for manipulating LIBOR. ${ }^{11}$ Regulators faulted Diamond for fostering a "toxic culture"; British politicians called him "rotten," "grossly incompetent," and "complicit and negligent." 12 That (stating Barclays paid " $£ 3.7$ billion ( $\$ 5.7$ billion) in currency market manipulation litigation costs in 2014 as well as costs associated with dealing with a number of retail investor misselling scandals and writedowns from property loan portfolios.”).

7. Titcomb, supra note 1.

8. See John Kiff, Back to Basics: What is LIBOR?, 49 InT'L MONETARY Fund 4, Dec. 2012, http://www.imf.org/external/pubs/ft/fandd/2012/12/basics.htm [perma.cc/9BJF-U89T] ("LIBOR's importance derives from its widespread use as a benchmark for many other interest rates at which business is actually carried out.").

9. Eyk Henning, David Enrich \& Jenny Strasburg, Deutsche Bank Co-CEOs Jain and Fitschen Resign, Wall ST. J. (June 7, 2015, 11:57 a.m. ET), http://www.wsj.com/articles/ deutsche-bank-co-ceos-to-announce-resignations-1433674815 [perma.cc/235W-UTJP].

10. Jack Ewing, Deutsche Bank Profit Falls on Legal Costs, N.Y. TIMES, (Apr. 26, 2015), http://www.nytimes.com/2015/04/27/business/dealbook/deutsche-bank-profit-fallson-legal-costs.html?_r=0 [perma.cc/TW8C-ZZAT]. Companies sometimes must also cut their capital expenditures because of illegal activity to be able to pay for resulting fines and litigation fees. See, e.g., Victor Luckerson, Volkswagen Will Cut \$1 Billion in Spending After Cheating Scandal, Time (Nov. 20, 2015), http://time.com/4122514/volkswagen-willcut-1-billion-in-spending-after-cheating-scandal/ [perma.cc/C9RU-Q8YS] (describing Volkswagen's cost spending as a result of paying for a cheating scandal).

11. Liam Vaughan \& Ambereen Choudhury, Barclays CEO Quits After Record LiborRigging Fine, BuSINESSWEEK (July 3, 2012), http://www.businessweek.com/articles/201207-03/barclays-ceo-quits-after-record-libor-rigging-fine [perma.cc/5UYB-AFKR].

12. Brinded, supra note 6 . The Barclays' board hired Antony Jenkins, a retail banker whose nicknames included "Mr. Nice," as Diamond's successor in 2012 to restore the bank's tattered reputation. Jenkins measured performance by and pegged bonuses to compliance with "a set of core values, including integrity and respect for others," and started to gut the investment banking operations, a historic money maker. After Barclays' stock continued to languish, the board replaced Jenkins with a new executive chair John 
same year, the Swiss bank, UBS, paid regulators $\$ 1.5$ billion to settle similar charges. ${ }^{13}$ In 2013, the European Commission fined Deutsche Bank, Barclays, Société Générale, the Royal Bank of Scotland, UBS, JPMorgan, Citigroup, and RP Martin a combined $€ 1.71$ billion (about \$2.3 billion) to settle similar charges. ${ }^{14}$ In September 2015, Goldman Sachs, together with some of Wall Street's biggest financial institutions, agreed to a $\$ 1.87$ billion settlement with investors to resolve allegations that the firms conspired to limit competition in the lucrative credit-default swaps market. ${ }^{15}$ British multinational bank, HSBC, agreed in 2012 to pay a record $\$ 1.92$ billion to settle international money laundering charges. ${ }^{16}$

In an effort to combat illegal conduct by senior executives of banks operating in Britain, British regulators announced in mid-2015 that bonuses paid to such executives could be clawed back, that is, confiscated, for up to

McFarlane in July 2015. Id. McFarlane indicated that Jenkins "hadn't done anything wrong ... he's just not the right person to take us forward." Id. McFarlane charged: "Barclays is not efficient, we are not productive, we are cumbersome." Id. He continued: "We have [a] very large bureaucracy and personal accountability is not as high as we need it to be. And so it's not just a reduction in costs, it's a change in the way we do things that's required here." $I d$.

For his part, Jenkins commented:

In the summer of 2012, I became Group Chief Executive at a particularly difficult time for Barclays. It is easy to forget just how bad things were three years ago both for our industry and even more so for us. I am very proud of the significant progress we have made since then. Most of all, I am proud that we have defined our culture through a common set of values for the Group and that the progress we have made and the tough decisions we have needed to take have all been achieved by applying these values and by focusing on the needs of all our stakeholders.

Id. It remains to be seen whether McFarlane can combine the high-flying Barclays under Diamond, when "Barclays was all about risk, high returns, and a focus on cutting-edge trading technology," with the values-driven culture under Jenkins. Id.

13. David Enrich \& Jean Eaglesham, UBS Admits Rigging Rates in 'Epic' Plot, WALL
ST. $\mathrm{J}$.
(Dec.
20 ,
2012,
$7: 17$
a.m.
ET),

http://online.wsj.com/articles/SB 10001424127887324407504578188342618724274

[perma.cc/QR9B-X9XW].

14. Lianna Brinded, Libor Fixing Scandal: Deutsche Bank 'Braces Itself' for $€ 1$ bn US and UK Fine, INT'L BUS. TIMES (Oct. 24, 2014, 15:18 BST), http://www .ibtimes .co.uk/liborfixing-scandal-deutsche-bank-braces-1bn-us-uk-fine-1471650 [perma.cc/BJ6A-PG7U].

15. See Jesse Drucker \& Bob Van Voris, Wall Street Banks to Settle CDS Lawsuit for $\$ 1.87$ Billion, BLOOMBerg Bus. (Sept. 11, 2015), http://www.bloomberg.com/news/articles/201509-11/wall-street-banks-reach-settlement-on-cds-lawsuit-lawyer-says [perma.cc/YG69R73Z] (describing Goldman Sachs Group Inc., JPMorgan Chase, Citigroup, and HSBC's settlement).

16. See Ben Protess \& Jessica Silver-Greenberg, HSBC to Pay $\$ 1.92$ Billion to Settle Charges of Money Laundering, N.Y. TIMES (Dec. 10, 2012, 4:10 PM), http://dealbook.nytimes.com/2012/12/10/hsbc-said-to-near-1-9-billion-settlement-overmoney-laundering/ [perma.cc/6CQC-ERY8]. 
ten years after any misconduct. ${ }^{17}$ Martin Wheatley, chief executive of Britain's Financial Conduct Authority, called this "a crucial step to rebuild public trust in financial services and allows firms and regulators to build long-term decision-making and effective risk management into people's pay packets." 18

Sweeping insider trading charges against Wall Street titans resulted in criminal sentences for once-venerated figures. ${ }^{19}$ They include Rajat Gupta, the former head of McKinsey \& Company and a former board member of Goldman Sachs, ${ }^{20}$ and hedge fund mogul Raj Rajaratnam of the now defunct Galleon Group (in its time, one of the world's largest hedge funds). ${ }^{21}$

Beyond draining a firm's financial capital and landing its executives in prison, ethical lapses in judgment can deplete a firm's reputational capital, in some cases tarnishing the brand irreparably. Even though the Supreme Court ultimately exonerated Enron's auditor, Arthur Andersen, of securities fraud, that ruling came too late to save the venerable accounting firm. ${ }^{22}$

The brands of multiple automobile companies have been eroded by the sale of unsafe or non-compliant vehicles. In 2014, Toyota paid a record $\$ 1.2$ billion fine to settle U.S. government charges related to as many as eighty-nine deaths allegedly caused by "unintended acceleration." 23

17. Chad Bray, British Regulators Extend Clawback Rules for Bankers' Pay, N.Y. TIMES (June 23, 2015), http://www.nytimes.com/2015/06/24/business/dealbook/britainbonuses-banks.html [perma.cc/U7A7-NTAG].

18. Id.

19. See Peter Lattman \& Azam Ahmed, Rajat Gupta Convicted of Insider Trading, N.Y. TIMES (June 15, 2012), http://dealbook.nytimes.com/2012/06/15/rajat-gupta-convictedof-insider-trading/?_r=0 [perma.cc/9QTF-ZAF6] (noting that United States attorney for Manhattan Preet Bharana charged "66 Wall Street traders and corporate executives ... with insider trading" from 2009 to 2012).

20. See id. (describing Gupta as the "most prominent corporate executive convicted in the government's sweeping investigation into insider trading.").

21. Peter Lattman \& Azam Ahmed, Hedge Fund Billionaire is Guilty of Insider Trading, N.Y. TIMES (May 11, 2011, 10:50 AM), http://dealbook.nytimes.com/2011/05/11/ rajaratnam-found-guilty/ [perma.cc/G9LH-LXAA].

22. Arthur Andersen LLP v. United States, 544 U.S. 696 (2005).

23. Alex Davies, Toyota Will Pay $\$ 1.2$ Billion to Settle Criminal Investigation Over Unintended Acceleration Case, Bus. INSIDER (Mar. 19, 2014), http://www.businessinsider.com/toyota-to-pay-12-billion-in-unintended-acceleration-case2014-3; Associated Press, Sudden Acceleration Death Toll Linked to Toyota Rises, N.Y. TiMES (May 25, 2010), http://www.nytimes.com/2010/05/26/business/26toyota.html [perma.cc/T5ZS-X5EH]. See also Comm. On Commerce, Science \& Transportation, Danger Behind The Wheel: The Takata Airbag Crisis And How To Fix Our Broken $\begin{array}{lllll}\text { Auto ReCAll } & \text { Process } 22, & \text { (June }\end{array}$ http://business.cch.com/plsd/SenateTakataAirBagReportJune2015.pdf [perma.cc/DK2P- 
Former Attorney General Eric Holder called Toyota's conduct "shameful" and said it "showed a blatant disregard for ... the safety of consumers" and was "a clear and reprehensible abuse of the public trust." another automobile industry debacle, Martin Winterkorn, the CEO of Volkswagen AG, resigned in September $2015^{25}$ after the company "admitted that it had installed ... software created to cheat on emissions tests in 11 million of its vehicles worldwide, setting off one of the largest corporate scandals in the auto industry." ${ }^{26}$ The illegal software permitted diesel-powered vehicles to pass emissions tests when they actually were emitting nitrogen oxide at "up to 40 times the federal standard." 27 According to the BBC, "The company admitted to 'totally screwing up', and there has been a shake-up in the management structure and personnel as a result." ${ }^{28}$ Winterkorn acknowledged responsibility, but said: "I am not aware of any wrongdoing on my part." ${ }^{29}$ On January 4, 2016, the U.S. Department of Justice sued Volkswagen AG, Audi AG, Porsche AG, and certain American subsidiaries for alleged violations of Sections 203 and 204 of the Clean Air Act, ${ }^{30}$ including "[s]elling, introducing into commerce, or importing into the United States motor vehicles that are designed differently from what Volkswagen had stated in applications for certification to EPA and the California Air Resources Board (CARB)." ${ }^{31}$

KG97] (report on the Takata's malfunctioning airbags).

24. Dep't of Justice, Remarks as Prepared for Delivery by Attorney General Eric Holder at the Press Conference Announcing Criminal Charges and Deferred Prosecution Agreement with Toyota Motor Corporation (Mar. 19, 2014), http://www.justice.gov/opa/speech/remarks-prepared-delivery-attorney-general-eric-holderpress-conference-announcing [perma.cc// WX2C-AKE7].

25. See Thad Moore, Volkswagen CEO Quits Amid Emissions-Cheating Scandal, WASH. POST (Sept. 23, 2015), http://www.washingtonpost.com/business/economy/volkswagen-ceo-resigns-afteremissions-cheating-scandal-spreads/2015/09/23/6b09e540-6203-11e5-8e9e-

dce8a2a2a679_story.html [perma.cc/9F9J-R37W] ("VW acknowledged this week that 11 million of its vehicles worldwide ... pass emissions tests while emitting nitrogen oxide at up to 40 times the federal standard.").

26. Coral Davenport \& Danny Hakim, U.S. Sues Volkswagen in Diesel Emissions Scandal, N.Y. Times, Jan. 5, 2016, at B1.

27. Moore, supra note 25.

28. VW Sued by US Justice Department, BBC (Jan. 4, 2016), http://www.bbc.com/ news/business-35227435 [perma.cc/MP4P-RPR4].

29. Moore, supra note 25.

30. 42 U.S.C. $\S \S 7523,7524$ (2012).

31. Press Release, U.S. Dep't. of Justice, United States Files Complaint Against Volkswagen, Audi and Porsche for Alleged Clean Air Act Violations (Jan. 4, 2016), http://www.justice.gov/opa/pr/united-states-files-complaint-against-volkswagen-audi-andporsche-alleged-clean-air-act [perma.cc/DPN5-B6XQ]. The complaint in United States $v$. Volkswagen $A G$ is available at http://www.justice.gov/opa/file/809826/download [perma.cc/3LE4-MTHC]. 
The Justice Department indicated that "the complaint represented the first step in legal action against Volkswagen and did not preclude a criminal charge or the targeting of specific executives." 32 Regulators in Germany, India, and South Korea are also investigating Volkswagen's deceptive practices. ${ }^{33}$ The company has already reserved more than $\$ 7$ billion to cover recall costs, and experts predict the final costs will be "much higher than that.",34

As of October 2015, BP's 2010 Deepwater Horizon oil drilling rig explosion - which resulted in eleven fatalities ${ }^{35}$ and represented the largest marine oil disaster in history ${ }^{36}$ - had resulted in a nearly $\$ 54$ billion pre-tax charge for the company. ${ }^{37}$ Included in that amount is a $\$ 5.5$ billion fine for violating the Clean Water Act. ${ }^{38}$ Two BP Deepwater Horizon supervisors were indicted for involuntary manslaughter in a 23-count indictment, which "accuses them of mishandling an important safety test and failing to report abnormally high pressure readings that attorneys say were obvious signs of an impending disaster." ${ }^{39}$ Critics blame BP's consistent pattern of unsafe behavior on a flawed corporate culture that condones such conduct. ${ }^{40}$

Of even more significance to companies than monetary damages and impaired reputational capital can be the diminishment of moral capital due to unethical behavior. Moral capital is critical to long-term firm success; once lost, it is very difficult to regain. Working for an employer that is ethical is important to millennials. A 2013 survey conducted by Bentley University found that $85 \%$ of millennials want to work for a socially

32. Davenport \& Hakim, supra note 26 , at B3.

33. Id.

34. VW Sued by US Justice Department, supra note 28. See also Mark Thompson \& Chris Liakos, Volkswagen CEO Quits over 'Grave Crisis', CNN MONEY (Sept. 23, 2015, 12:43 PM ET), http://money.cnn.com/2015/09/23/news/companies/volkswagen-emissionscrisis/ [perma.cc/K4D4-QHUU] ("The company faces civil and possible criminal fines in the U.S. that are likely to total billions of dollars.").

35. See Mary Flood, Jury's Out on Edge for Lawyers Who've Battled BP Before, Houston Chron. (May 23, 2010) (reporting fifteen BP workers were killed in an explosion at its Texas City refinery in 2005).

36. See Emily Atkin, BP Rig Supervisors Must Face Manslaughter Charges for Deepwater Horizon Deaths, Judge Rules, ClimateProgress (Jan. 29, 2014, 11:46 AM), http://thinkprogress.org/climate/2014/01/29/3220691/deepwater-death-jury/ [perma.cc/YS28-K88D] (discussing the charges against Deepwater Horizon).

37. Susan Heavey, U.S. Says BP to Pay $\$ 20$ Billion in Fines for 2010 Oil Spill, REUTERS (Oct. 5, 2015, 2:09 EDT), http://www.reuters.com/article/us-bp-usaidUSKCNORZ14A20151005 [perma.cc/3LBA-KYFB]

38. Id.

39. Atkin, supra note 36.

40. See generally Jad Mouawad, For BP, a History of Spills and Safety Lapses, N.Y. Times (May 8, 2010), http://www.nytimes.com/2010/05/09/business/09bp.html? pagewanted=all [perma.cc/PJ8L-HY4V] (detailing BP's previous safety lapses). 
responsible or ethical company, with $95 \%$ indicating that a company's reputation is important. ${ }^{41}$ More than half of the respondents indicated that they have concerns about "whether most businesses do the right thing.,"

Corporate scandals of this scale are certainly not unprecedented, though they appear to be happening more frequently. There was roughly a ten-year gap between the savings and loan ("S\&L") ${ }^{43}$ and insider trading scandals $^{44}$ in the 1980s and the collapse of Enron and WorldCom in 2001. The demise of these and other former high flyers was followed in relatively short order by the hedge fund insider trading scandals that began with a tip in 2007 about hedge fund trader Rengan Rajaratnam, ${ }^{45}$ then the subprime

41. See Rob Asghar, Study: Millennials' Work Ethic Is in the Eye of the Beholder, FORBES.COM (Jan. 29, 2014, 10:21 AM), http://www.forbes.com/sites/robasghar/2014/ 01/29/study-millennials-work-ethic-is-in-the-eye-of-the-beholder/ [perma.cc/V8DZ-WP6L] (noting more than 3,000 individuals participated in the October 2013 survey, including students, recent college graduates, parents, and employers).

42. $I d$.

43. See generally FDIC, 1 An EXAMINATION OF THE BANKING CRISES OF THE 1980S AND EARLY 1990s 168, https://www.fdic.gov/bank/historical/history/167_188.pdf [perma.cc/ 6YVD-JD2Z] (last visited Dec. 24, 2015) (The Federal Deposit Insurance Corporation ("FDIC") estimated that it cost "just over $\$ 160$ billion, including \$132 billion from federal taxpayers," to bail out failed savings and loans ("S\&Ls"). The FDIC explained, "believing that the marketplace would provide its own discipline, the government used rapid deregulation and forbearance instead of taking steps to protect depositors. The government guarantee of insured deposits nonetheless exposed U.S. taxpayers to the risk of loss - while the profits made possible by deregulation and forbearance would accrue to the owners and managers of the savings and loans." Of the 1,043 S\&Ls that failed from 1986 to 1995 , Lincoln Savings and Loan was the largest.). See also Robert D. McFadden, Charles Keating, 90, Key Figure in '80s Savings and Loan Crisis, Dies, N.Y. TimES (Apr. 2, 2014), http://www.nytimes.com/2014/04/02/business/charles-keating-key-figure-in-the-1980ssavings-and-loan-crisis-dies-at-90.html?_r=0 [perma.cc/2CA8-K9NM] (explaining that twenty-thousand customers "were left holding \$250 million in worthless bonds, the life savings of many."). Even though Lincoln's expert Alan Greenspan had opined before he became chair of the Federal Reserve Board that Lincoln's depositors faced "no foreseeable risk," U.S. taxpayers ultimately had to pay $\$ 3.4$ billion to cover the S\&L's depositors' losses. Id. Its CEO, Charles Keating, was convicted in 1992 of racketeering, fraud, and conspiracy and went to prison for four and a half years. Although his convictions were overturned on appeal in 1996, Keating pleaded guilty in 1999 to four counts of wire and bankruptcy fraud, at which point he was sentenced to time already served. Id.

44. See generally James B. Stewart, Den of Thieves (1991) (detailing insider trading scandals).

45. See Matthew Goldstein, Ben Protess \& Rachel Adams, Prosecutors' Winning Streak on Insider Trading Cases Ends, N.Y. Times (July 8, 2014), http://dealbook.nytimes.com/2014/07/08/jury-clears-rengan-rajaratnam-in-insider-tradingcase/ [perma.cc/TGQ4-YZQR] (discussing the 2007 tip led to the 2009 arrest of Rengan's older brother Raj Rajaratnam, the co-founder of the Galleon Group hedge fund, and his 2011 conviction. In July 2014, after securing eighty-five insider trading convictions and guilty pleas, the government's "winning streak" ended when Rengan Rajaratnam was found not guilty of conspiracy to commit insider trading with his brother.). 
mortgage crisis in 2008, the LIBOR rigging scandals in 2012, and then the foreign exchange manipulation cases.

After each new financial crisis in the United States, Congress has enacted new legislation "to address the perceived causes of the crisis." 46 Congress passed the Glass-Steagall Act in $1933,{ }^{47}$ the Securities Act of $1933,{ }^{48}$ and the Securities Exchange Act of $1934^{49}$ in response to the Stock Market Crash of 1929. It enacted the Financial Institutions Reform, Recovery, and Enforcement Act of 1989 ("FIRREA") debacle," 51 which cost "just over $\$ 160$ billion, including $\$ 132$ billion from federal taxpayers," to bail out failed savings and loans ("S\&Ls"), which had made increasingly risky investments to shore up their depleted reserves. ${ }^{52}$ Congress passed the Sarbanes-Oxley Act of 2002 ("SOX") after the implosion of Enron, WorldCom, ${ }^{54}$ and Tyco, and other corporate scandals ${ }^{55}$ then enacted the Dodd-Frank Wall Street Reform and Consumer Protection Act of 2010 ("Dodd-Frank") ${ }^{56}$ in the wake of the subprime mortgage crisis.

46. Kabir Ahmed \& Dezso Farkas, A Proposal to Encourage Up-the-Ladder Reporting by Insulating In-house Corporate Attorneys from Managerial Power, 39 DEL. J. CORP. L. 861,863 (2015).

47. Banking Act of 1933, Pub. L. No. 73-66, 48 Stat. 162 (1933) (codified as amended in scattered sections of 12 U.S.C.).

48. Pub. L. No. 73-22, 48 Stat. 74 (1933) (codified as amended at 15 U.S.C. $\$ 77$ a $77 \mathrm{~mm})$. $78 \mathrm{kk})$

49. Pub. L. No. 73-291, 48 Stat. 881 (1934) (codified as amended at 15 U.S.C. § 78a-

50. Pub. L. No. 101-73, 103 Stat. 183 (1989) (codified as amended in scattered sections of 12 U.S.C.).

51. FDIC, supra note 43, at 167.

52. Id. at 187 .

53. Pub. L. No. 107-204, 15 U.S.C. $\S 7201$ et seq. (2003). Suraj Srinivasan, the coauthor, with John C. Coates IV, of SOX after Ten Years: A Multidisciplinary Review, 28 ACCT. HORIZONS 627 (2014), concluded: "Markets have been able to use the information to assess companies more effectively, managers have improved internal processes, and the internal control testing has become more cost-effective over time."' (quoted in Julia Hanna, The Costs and Benefits of Sarbanes-Oxley, Forbes (Mar. 10, 2014, 11:15 AM)), http://www.forbes.com/sites/hbsworkingknowledge/2014/03/10/the-costs-and-benefits-ofsarbanes-oxley/ [perma.cc/CE5E-JKWL]) (explaining that 33\% of large-company chief financial officers surveyed by the Financial Executives Research Foundation in 2005 agreed that SOX had reduced fraud).

54. See Ahmed \& Farkas, supra note 46, at 863 (discussing the history of financial scandals).

55. See Sung Hui Kim, The Banality of Fraud: Re-Situating the Inside Counsel as Gatekeeper, 74 FORDHAM L. REV. 983, 985-86 (2005) (discussing financial fraud by corporations).

56. Pub. L. No. 111-203, § 929-Z, 124 Stat. 1376, 1871 (2010) (codified at 15 U.S.C. $\S$ $780)$ 
Notwithstanding the passage of SOX and the enactment of the SEC regulations thereunder, "the financial crisis of 2008 still happened." 57 As the co-author of a study of the ten-year effect of SOX stated, "The big, unanswered question is whether SOX-related changes had any impact in the lead-up to the financial crisis [of 2008]. Did it make things better or worse?"58 He continued, "We don't know the answer to that. We only know that there were benefits in terms of financial reporting and corporate governance; that costs of implementation were higher for smaller companies; and that concerns about risk-taking and investment haven't come to bear." $" 59$

Similarly, even after the enactment of Dodd-Frank, the most sweeping financial reform since the Great Depression, ${ }^{60}$ and one of its predecessor statutes - the Foreign Corrupt Practices Act of 1977 ("FCPA") reporting lapses and bribery continued. The cosmetics company Avon settled FCPA charges in 2014 for $\$ 135$ million (one of the largest fines collected from a U.S. company); the company estimates that it spent an additional $\$ 300$ million on its own internal investigation. ${ }^{62}$ That same year, the Chinese government fined GlaxoSmithKline ("GSK”) \$491.5 million for bribing Chinese physicians and healthcare organizations, the largest corporate fine ever levied by Chinese authorities. ${ }^{63}$ Mark Reilly, the head of GSK's Chinese operations, pleaded guilty to bribery and was deported. ${ }^{64}$ Glaxo called the "illegal activities" of GSK China Investment Co. "a clear breach of GSK's governance and compliance procedures" and said they "are wholly contrary to the values and standards expected from GSK employees." G5 Glaxo issued an apology in both Chinese and English "to

57. Hanna, supra note 53.

58. Id.

59. Id.

60. See Brady Dennis, Obama Ushers in New Financial Era, Wash. Post, July 22, 2010, at A13 (discussing the significance of Dodd-Frank).

61. 15 U.S.C. $\S 78 \mathrm{dd}-1$ (1977).

62. Phil Wahba, Avon Settles Justice Department Charges of China Bribery for $\$ 135$ Million, ForTunE (Dec. 17, 2014, 6:02 PM EST), http://fortune.com/2014/12/17/avonbribery-probe-settlement/ [perma.cc/26FZ-9RTM]. In August 2015, Avon sought court approval of a $\$ 62$ million private settlement arising out of the same bribery allegations. Avon Seeks Approval in U.S. of $\$ 62 \mathrm{ml}$ Accord over China Bribery, REUTERS (Aug. 18, 2015, 12:55pm EDT), http://www.reuters.com/article/avon-corruption-settlementidUSL1N10T1B720150818.

63. Hester Plumridge \& Laurie Burkitt, GlaxoSmithKline Found Guilty of Bribery in $\begin{array}{lllllll}\text { China, WALl ST. J. (Sept. 19, 2014, 2:15 p.m. ET), } & \text { S. }\end{array}$ http://www.wsj.com/articles/glaxosmithkline-found-guilty-of-bribery-in-china-1411114817 [perma.cc/4EE6-8YYN].

64. Id.

65. Id. 
the Chinese patients, doctors and hospitals and to the Chinese government and the Chinese people." 66

All of these companies had general counsel. So, once again, as Judge (and former head of the Enforcement Division at the Securities and Exchange Commission) Stanley Sporkin famously asked, "Where were the lawyers?"67 To that we add, "Where were the managers?"

We believe that an examination of the historical underpinnings of the corporate environment in which counsel and managers currently find themselves provides an insightful lens through which to examine the persistent failure of major firms in the United States, Europe, and Asia to comply with the law. We submit that legislation and regulatory action alone are, and will continue to be, insufficient to deter corporate misconduct of the sort we have experienced in the last two decades. Instead, more attention should be paid to internal forces within firms. In particular, we argue that the shift in general counsel's role from "cop" to "entrepreneur" has made it more difficult for general counsel to fulfill their special duties as officers of the court and as corporate conscience. In addition, the elimination of required MBA courses in business law in many business schools has left future business leaders ill-equipped to manage the legal and ethical aspects of business. As discussed in Part V, the resultant lack of "legal literacy" 68 has been compounded by the mantra of shareholder primacy taught in many economics and finance classes. ${ }^{69}$

In this Article, we assert that counsel and managers can be more

66. Id.

67. See Lincoln Sav. \& Loan Ass'n v. Wall, 743 F. Supp. 901, 920 (D.D.C. 1990) (noting that while there were "literally scores of accountants and lawyers" in a case involving the savings and loan scandal, Judge Sporkin wrote: "Where were these professionals ... ? Why didn't any of them speak up or disassociate themselves from the transactions? Where also were the outside accountants and attorneys when these transactions were effectuated?"); Egon Guttman \& Stanley Sporkin, The Evolving Legal and Ethical Role of the Corporate Attorney After the Sarbanes-Oxley Act of 2002, 52 AM. U. L. REV. 639, 641 (2003) (paraphrasing Judge Sporkin's question as, "Where were the lawyers?").

68. Constance E. Bagley, Winning Legally: The Value of Legal Astuteness, 33 ACAD. Mgmt. Rev. 378 (2008).

69. See generally Lynn A. Stout, The Shareholder Value Myth: How Putting SHAREHOlders First HARMS InVESTORS, CORPORATIONS, AND THE PUbliC (2012) (debunking the myth that corporate law requires shareholder primacy); Constance E. Bagley, Shareholder Primacy Is a Choice Not a Legal Mandate in 1 ThE AcCountable CORPORATION 85-105 (Marc J. Epstein \& Kirk O. Hanson, eds., 2005) (discussing duties of directors to the corporation and shareholders in further detail); Constance E. Bagley \& Karen Page, The Devil Made Me Do It: Replacing Corporate Directors' Veil of Secrecy with the Mantle of Stewardship, 36 SAN DIEGO L. REV. 897 (1999) (arguing that the nature of the corporate form as well as an exclusive focus on shareholder value leads to economically and socially inefficient results). 
effective drivers of both compliant corporate behavior and the creation of sustainable value when they work together as strategic partners. This requires both managers and counsel to accept responsibility for ensuring that the firm's economic success is predicated on integrity, honesty, and compliance with not just the letter of the law but its spirit and societal norms as well. Legally astute top management teams ("TMTs") embrace their responsibilities as guardians of the firm's financial, human, legal, and ethical capital. They understand that just as war is too important to leave to the generals, ${ }^{70}$ so legal matters are too important to leave to the lawyers. ${ }^{71}$ Instead, as we discuss in Part IV, they practice "strategic compliance management." ${ }^{, 72}$

In Part I, we provide a brief history of the changing role of general counsel in the United States, then in Part II we discuss four of the five components of legal and strategic astuteness: (1) a set of value-laden attitudes; (2) a proactive approach; (3) the exercise of informed judgment; and (4) context-specific knowledge regarding the use of the law and legal and managerial tools to increase realizable value, marshal and redeploy resources, and manage risk. We address the fifth element, partnership with strategically astute legal counsel (and, in the case of counsel, legally astute managers), ${ }^{73}$ in Part III. In Part IV, we explain how legally astute top management teams advised by strategically astute lawyers can increase firm value by (1) using formal contracts as complements to relational governance to reduce transaction costs and strengthen relationships, (2) using legal tools, such as intellectual property rights, to protect, leverage, and transform the realizable value of knowledge assets and other firm resources, (3) creating valuable options, (4) practicing "strategic compliance management,"74 and (5) helping change and shape the legal and regulatory environment. ${ }^{75}$ Part $\mathrm{V}$ discusses how changes in the legal component of the courses required in various management programs,

70. Attributed to either French Prince Charles Maurice de Talleyrand or French Prime Minister Georges Clemenceau. See Eric von Der Luft, God, Evil, And Ethics: A Primer IN THE PHILOSOPHY OF RELIGION 7 (2004) (discussing the attribution of the quote).

71. Constance E. Bagley, Winning Legally: How to Use the Law to Create VAlue, MARShal ResourCes, AND MANAGE RisK 5 (2005).

72. Id. at 50-86.

73. See generally Constance E. Bagley \& Mark Roellig, The Transformation of General Counsel: Setting the Strategic Legal Agenda, in Legal RisK Management, Governance AND COMPLIANCE (Stuart Weinstein \& Charles Wild eds. 2013) (discussing the role of general counsel); Constance E. Bagley, The Value of a Legally Astute Top Management Team: A Dynamic Capabilities Approach, in OXFORD HANDBOOK OF DYNAMIC CAPABILITIES (David Teece ed., forthcoming) (discussing the value of a legally astute management team).

74. BAGLEY, supra note 71 .

75. Id. 
especially those leading to a Master in Business Administration ("MBA"), and the continued focus on the ill-conceived notion that the law requires "shareholder primacy," adversely affects business leaders' ability to win with integrity. We also discuss the steps the main accrediting body AACSB International has taken to address that deficit, and we offer suggestions for training more strategically astute lawyers. Part VI describes the evolving role of in-house counsel outside the United States, discussing changes in the rules governing lawyers in the United Kingdom and presenting new data on the role of in-house lawyers in Sweden. We argue that our prescriptions for heightened legal and strategic astuteness are appropriate for firms based outside the United States as lawyers in other countries become more entrepreneurial.

\section{A BRIEF HISTORY OF THE CHANGING ROLE OF GENERAL COUNSEL IN THE UNITED STATES}

The role of general counsel within large American corporations has evolved considerably from the late nineteenth century to the present, undergoing both falls and rises in their power and prominence. Unlike its mid-twentieth-century embodiment, the modern position is one of great prestige.

\section{A. Period of Prestige: Post-Civil War through 1930s}

Prior to the 1930s, general counsel enjoyed a golden age of power and prominence, and corporate legal positions were highly desirable. ${ }^{76}$ General counsel served both legal and business functions, and "their sage counsel was regularly sought" by corporate management. ${ }^{77}$ The position's high remuneration levels reflected this high status: counsel received roughly $65 \%$ of the Chief Executive Officer's salary, and they were often among a corporation's three highest paid executives. ${ }^{78}$ It was common at this time for companies to groom a member of their legal department to become CEO. Indeed, more than $75 \%$ of corporate CEOs in America had a legal background during this period, ${ }^{79}$ as businesses recognized the added value a legal education (and the analytical tools associated with that education)

76. See Lawrence M. Friedman, A History of American Law 490 (3d ed. 2005) (detailing the history of general counsels).

77. Carl D. Liggio, Sr., A Look at the Role of Corporate Counsel: Back to the Future-Or Is It the Past?, 44 ARIz. L. REv. 621, 621 (2002).

78. Id.

79. Edwin C. Mruk, Address to the Association of the Bar of the City of New York Committee on Corporate Law Departments (Nov. 1977). 
offered to their business concerns. ${ }^{80}$

\section{B. Period of Decline: 1940s through Mid-1960s}

The 1940s onward, however, saw a steady decline in the power and prominence of the general counsel position due to the rise of Master of Business Administration degree holders, the new "wunderkinds of the business community." ${ }^{\prime 1}$ American corporations increasingly favored business over legal education as the preferred background for senior management. Accordingly, companies' hiring and promotion trends shifted in favor of MBA graduates as the cohort from which companies would choose their top leadership. ${ }^{82}$

Further compounding the decline of general counsel during this period was the growth of outside law firms serving corporations' increasingly complex legal needs. ${ }^{83}$ With the ascendancy of MBAs came a corollary decline in corporate America's esteem for inside counsel, which resulted in a diminished dependence on that counsel. ${ }^{84}$ General counsel's income declined accordingly to about $30 \%$ of the CEO's by the mid-1970s, causing top lawyers to avoid, rather than vie for, corporate counsel positions. ${ }^{85}$ General counsel devolved into a "relatively minor management figure, stereotypically, a lawyer from the corporation's principal outside law firm who had not quite made the grade as partner." 86 In-house lawyers managed "corporate housekeeping" matters, and they acted as a liaison to, and not manager of, the outside legal firm. ${ }^{87}$

\section{Period of Renaissance: Mid-1960s through 1980s}

Beginning roughly in the mid-1960s and the early 1970s, a confluence of factors spawned the rise of general counsel in both power and

80. See Carl D. Liggio, The Randolph W. Thrower Symposium: The Role of the General Counsel: Perspective: The Changing Role of Corporate Counsel, 46 EMORY L.J. 1201, 1201-02 (1997) (discussing the added value of a legal education for CEOs).

81. Liggio, supra note 77 , at 621 .

82. See Liggio, supra note 80, at 1202 ("Suddenly, marketers and financial types became the new 'wunderkinds;' this corporate focus was then reflected in the hiring trends of businesses. It is from this group that senior management was now selected.").

83. Debora A. DeMott, The Discrete Roles of General Counsel, 74 Fordham L. ReV. 955, 958-59 (2005).

84. Liggio, supra note 80, at 1202.

85. Id.

86. Abram Chayes \& Antonia H. Chayes, Corporate Counsel and the Elite Law Firm, 37 STAN. L. REV. 277, 277 (1985).

87. $I d$. 
prominence. First, an unprecedented growth in federal business regulations presented corporations with increasingly complex legal compliance issues, ${ }^{88}$ which, in turn, led to increased corporate demand for and dependence on outside legal services. ${ }^{89}$ These regulations included Title VII of the Civil Rights Act of $1964,{ }^{90}$ the National Environmental Policy Act of $1969,{ }^{91}$ the Occupational Safety and Health Act of $1970,{ }^{92}$ the Fair Credit Reporting Act of $1970,{ }^{93}$ the Employee Retirement Income Security Act of 1974, ${ }^{94}$ and the Foreign Corrupt Practices Act of $1977 .{ }^{95}$ Second, increased regulation prompted a corollary increase in the already high legal fees corporations paid to outside law firms. ${ }^{96}$ Magnifying this effect was the ballooning volume of business litigation generally characteristic of this period. $^{97}$

What ensued was a resurgence of inside counsel's former power and prominence. ${ }^{98}$ As outside legal firms became more powerful, the high costs

88. Liggio, supra note 80 , at 1203-04.

89. Larry E. Ribstein, Symposium: The Changing Role and Nature of In-House and General Counsel: Delawyering the Corporation, 2012 WIS. L. REV. 305, 308 (2012).

90. 42 U.S.C. $\$ 2000 \mathrm{e}(1964)$.

91. 42 U.S.C. $\$ 4321$ (1969).

92. 29 U.S.C. $\$ 651(1970)$.

93. 15 U.S.C. $\$ 1681(1970)$.

94. Pub. L. No. 93-406, 88 Stat. 829 (codified as amended in scattered sections of 5

U.S.C., 18. U.S.C., 26 U.S.C., 29 U.S.C., and 42 U.S.C.).

95. 15 U.S.C. $\$ 78 d d-1$ (1977).

96. DeMott, supra note 83, at 960; Liggio, supra note 80, at 1204 :

In 1963, the starting salary at a Wall Street law firm salaries [sic] was $\$ 7,200$, less than what the law firms then paid a good, experienced secretary. Billing rates for new attorneys at the premier firms started at a mere $\$ 17$ per hour, and partner rates started at $\$ 45$ an hour. This stands in stark contrast to today's costs in the New York legal market. Today, starting salaries of $\$ 90,000$, over twice what a good, experienced secretary is paid, are not uncommon; billing rates for new associates average $\$ 115$ an hour, and partner billing rates average almost $\$ 450$ an hour.

By 2015 , starting salaries for $85 \%$ of new associates at firms with more than 250 lawyers in New York City were $\$ 160,000$; partner rates in New York City averaged $\$ 772$ an hour in 2014. Press Release, Nat'l Ass'n for Law Placement, First-Year Associate Salaries at Large Law Firms Have Become Less Homogenous, Though \$160,000 Continues to Define the Top of the Market (Apr. 16, 2015), http://www.nalp.org/uploads/PressReleases/ 2015ASSRPressRelease.pdf [perma.cc/647C-VFC7]; Jeffrey A. Lowe Esq., 2014 Partner Compensation Survey, MAJOR, LINDSEY \& AFRICA 48, http:/www.mlaglobal.com/ /media/ Allegis/MLAGlobal/Files/Partner\%20Compensation\%20Survey/2014/PCS_2014_Web_ 091214_FINAL.pdf [perma.cc/LXX2-MKVG] (last visited Dec. 28, 2015).

97. See Liggio, supra note 80 , at 1203 (noting that businesses "were now using the legal process as one more tool in the business planning process").

98. See id. ("Businesses, which previously had used only retained counsel, began to create or enlarge their own legal staffs. Those businesses that did not have legal staffs began to increase the quality and number of in-house lawyers."). 
associated with switching to another firm resulted in corporate overreliance on one firm. ${ }^{99}$ Because many elite law firms were not able or willing to adjust their fee structures, companies sought cheaper alternatives to outside counsel. ${ }^{100}$ Rather than be bound to one, uncompromising firm, corporations began to procure a series of outside firms that then competed for aspects of the company's business. ${ }^{101}$ Often, the general counsel oversaw this bidding process. This arrangement reduced the role of outside counsel to a commodity and disincentivized firms from developing company-specific knowledge about their corporate clients, thereby eliminating a tradition of close relationships between firms' partners and corporations' senior management. Companies that once exclusively retained outside counsel began to establish or expand their in-house legal departments using quality lawyers ${ }^{102}$ ultimately substituting outside counsel with inside counsel. ${ }^{103}$

As John Coffee explained, the general counsel

became as much a general manager of legal services as an actual counselor to management. For his or her own self-interested reasons, the general counsel typically did not want competition from outside counsel. He or she wanted to be the primary conduit of legal advice to management and hence sought to discourage any long-term, continuing relationship between senior management and outside counsel. As much from this reason as to encourage price competition, the in-house counsel moved legal business around, thereby assuring his or her own monopolistic position as the supplier of legal advice to senior management. What shifted then was not the relative number of insider versus outside counsel, but the balance of power between them. ${ }^{104}$

Reflecting this shift, the American Corporate Counsel Association ("ACCA") was established in $1980^{105}$ "to create a new identity for the lawyers formerly known as "house counsel,",106 who, by the 1980s,

99. See Ronald J. Gilson, The Devolution of the Legal Profession: A Demand Side Perspective, 49 MD. L. REV. 869, 915 (1990) ("If these functions are performed by outside counsel, then market power, measured by the switching costs created, accrues to outside counsel.").

100. Robert Eli Rosen, The Inside Counsel Movement, Professional Judgment and Organizational Representation, 64 IND. L.J. 479, 505 (1989).

101. Ribstein, supra note 89 , at 310.

102. Liggio, supra note 80 , at 1203.

103. Rosen, supra note 100 , at 505.

104. John C. Coffee Jr., Gatekeepers: The Professions and Corporate GOVERnANCE 224 (2006).

105. Chayes \& Chayes, supra note 86 , at 277 n.1.

106. David B. Wilkinsal, Is the In-House Counsel Movement Going Global? A Preliminary Assessment of the Role of Internal Counsel in Emerging Economies, 2012 WIS. 
performed an increasingly diverse set of nuanced roles. ${ }^{107}$ Robert Rosen dubbed the restoration of the power and prominence of general counsel the "age of enlightenment." "108

\section{Prestige at the Cost of Integrity?: 1980s to 2002}

Some argue that counsel's rise to prominence begat a proportionate decline in their professional and personal integrity. In 2000, Nelson and Nielsen published a study reporting that modern general counsel in the United States increasingly exhibited qualities of "entrepreneurialism," whereby "corporate counsel ... adapt[ed] their images and lawyering styles to the prerogatives of contemporary management." 109 One of three lawyer archetypes (the others being "cop" and "counsel"), the entrepreneurial lawyer "evolve[s] according to the needs of business," viewing law as a source of profits to be leveraged in the corporation's business strategy. ${ }^{110}$ In contrast, the "cop" role is primarily concerned with "policing the conduct" of "business clients," and "interact[ing] with business people almost exclusively through legal gatekeeping functions, such as approving contracts, imposing and implementing compliance programs, and responding to legal questions." ${ }^{111}$ The third role of "counsel" "implies a broader relationship with business actors that affords counsel an opportunity to make suggestions based on business, ethical, and situational concerns." 112 (Our data on the roles played by in-house lawyers in Sweden are set forth in Part VI.)

Unfortunately, as discussed in Part V, during this same period and

L. REV. 251, 277 (2012). Reflecting the increasing global nature of legal practice, the association dropped "American" from its name in 2003. Assoc. of Corp. Counsel, History and Heritage, ACC, http://www.acc.com/aboutacc/history/index.cfm [perma.cc/F44BYAZ3] (last visited Jan. 10, 2016).

107. "They managed and reviewed the legal services provided to corporate clients by outside counsel; they regularly supplied routine legal services and, on some occasions, directly handled complex transactions and even litigation; they counseled clients and their constituents on regulatory requirements; and they created compliance programs." Mary C. Daly, The Cultural, Ethical, and Legal Challenges in Lawyering for a Global Organization: The Role of the General Counsel, 46 EMORY L.J. 1057, 1061-62 (1997).

108. Rosen, supra note 100, at 488 ("No longer lacking resolution and courage, inside counsel exercise their own powers with advice from, but not at the direction of, outside counsel.").

109. Robert Nelson \& Laura Beth Nielsen, Cops, Counsel, and Entrepreneurs: Constructing the Role of Inside Counsel in Large Corporations, 34 LAW \& SOC'Y REV. 457, 457 (2000).

110. Id. at 466 .

111. Id. at 463 .

112. Id. at 464 . 
thereafter, many of the top business schools responded to the deregulation of a number of industries, such as airlines, by eliminating the core business law courses in their MBA programs, leaving future business leaders illequipped to work effectively with their newly empowered and arguably more easily coopted counsel to manage the legal, ethical, and financial aspects of business. ${ }^{113}$ In addition, as discussed further in Part V, the doctrine of shareholder primacy taught in many programs overstated the duty of directors to maximize shareholder value. The law governing the fiduciary duties of directors has evolved over time. As discussed further in Part V, except in extraordinary cases, ${ }^{114}$ shareholder primacy is a managerial choice not a legal mandate. ${ }^{115}$

The increased entrepreneurialism that Nelson and Nielsen found among U.S. general counsel in the 1990s is not surprising given the nature of that period, which was "characterized by the dot-com boom and highflying markets involving mergers and acquisitions (M\&As) and initial public offerings (IPOs)."116 During this period, general counsel were "prototypical Wall Street or Silicon Valley M\&A lawyers who had prior experience at the table with investment bankers." 117 Legal compliance was not necessarily their forte. Instead, the focus shifted to getting the deal done.

General counsel of this era continued to increase in professional and social stature and served as trusted confidants to the CEO and other members of senior management. This arrangement, however, raised concerns about the independence of general counsel and the risks of cooption: would counsel's personal interests and their relationships with senior management interfere with their ability to fulfill their fiduciary and

113. See Nitin Nohria \& Rakesh Khurana, Advancing Leadership Theory and Practice in HANDBOOK OF LEADERSHIP THEORY AND PRACTICE 3 (Nitin Nohria \& Rakesh Khurana eds., 2010) (asking if educational institutions are to blame for poor leaders); see also Where Will They Lead? 2008: MBA Student Attitudes About Business and Society, The AsPEN INSTITUTE (2008), https://www.aspeninstitute.org/sites/default/files/content/docs/bsp/SAS_PRINT_ FINAL.PDF [perma.cc/H4MZ-AV33] (last visited Dec.. 28, 2015) (noting that only a minority of M.B.A. students believed that business schools sufficiently addressed the ethical aspects of successful leadership); infra text accompanying notes 336-372 (discussing importance of legal training for business students).

114. These include when the break-up of the corporation or a sale of control has become inevitable. See Revlon, Inc. v. MacAndrews \& Forbes Holdings, Inc., 506 A.2d 173, 182 (Del. 1986) ("The duty of the board had thus changed from the preservation of Revlon as a corporate entity to the maximization of the company's value at a sale for the stockholders' benefit.").

115. Bagley, supra note 69.

116. June Eichbaum, Globalization and General Counsel, DIVERSITY \& THE BAR MAGAZINE, Aug. 2008, at 48.

117. Id. 
professional obligations to the corporation as officers of the corporation and of the court? ${ }^{118}$ Joseph Auerbach's answer to the question of whether inside counsel can wear two hats was an unequivocal "no." 119

In 1993, Yale Law School Dean Anthony Kronman warned that "the [American legal] profession now stands in danger of losing its soul." 120 His remedy is the lawyer-statesman ideal, the demise of which Kronman laments as a product of "the explosive growth of the country's leading law firms, which has changed forever the practice of the lawyers in them and created a new, more openly commercial culture in which the lawyerstatesman ideal has only a marginal place." ${ }^{21}$ This is not an entirely new phenomenon. As early as 1905, Supreme Court Justice Louis Brandeis warned that "lawyers have, to a large extent, allowed themselves to become adjuncts of great corporations and have neglected the obligation to use their powers as for the protection of people."122

The increasing entrepreneurial tendencies among general counsel and the concomitant deficits in the legal and ethical training of future managers were symptomatic of the major corporate scandals that followed. As more general counsel kowtowed to the prerogatives of senior management, they "limit[ed] their gatekeeping functions ... [by] defer[ring] to management's judgments about legal risk," ${ }^{23}$ giving undue "priority to business objectives rather than legal [imperatives]." options backdating scandals at Monster Worldwide Incorporated, McAfee Incorporated, and Brocade Communication Systems Incorporated, which led to criminal convictions of responsible managers, including general

118. See, e.g., Joseph Auerbach, Can Inside Counsel Wear Two Hats?, HARV. Bus. Rev., Sept.-Oct. 1984, at 80 (asking if in-house lawyers forfeit objectivity by taking part in corporate planning). Of course, even outside counsel are susceptible to client capture. See Hugh P. Gunz \& Sally P. Gunz, Client Capture and the Professional Service Firm, 45 AM. Bus. L.J. 685, 688 (2008) (explaining that capture occurs when "clients become so important to the professionals serving them that they lose the professional independence that is presumed by the profession to govern the relationship"). For example, even though Enron was the largest corporate client in Vinson \& Elkins' Houston office, and Vinson \& Elkins had created the special purpose entities challenged by an Enron whistleblower, the Enron audit committee relied on Vinson \& Elkins to provide a legal assessment of the charges. Robert A. Oppel Jr. \& Kurt Eichewald, Arthur Andersen Fires an Executive for Enron Orders, N.Y. TIMES, Jan. 16, 2002, at A2. This is a bit like asking teenagers to grade their own papers.

119. Auerbach, supra note 118.

120. Anthony Kronman, The Lost Lawyer: Failing Ideals of the Legal PROFESSION xiv (1993).

121. Id. at 4.

122. James M. Altman, Considering the A.B.A.'s 1908 Canons of Ethics, 71 FORDHAM L. Rev. 2395, 2406 (2003) (quoting LouIs D. BRANDEIs, Business: A PROFESSION 337 (1914)).

123. Nelson \& Nielsen, supra note 109.

124. Id. 
counsel, for accounting fraud. ${ }^{125}$ Counsel had become overly "comfortable" in their roles, causing them to, according to Donald Langevoort, "too readily [engage in] a process of collective rationalization" whereby "objectivity... [or] 'cognitive independence' [] is predictably diminished" and unethical legal risks are irrationally assumed. ${ }^{126}$ Indeed, more than $30 \%$ of firms "subject to civil or criminal investigations for illegal accounting of backdated stock options fired their general counsel." ${ }^{127}$

The end of the M\&A/Hot IPO era was replete with corporate scandals, most notably those that led to the collapse of Enron and WorldCom, but also those involving Arthur Andersen, Adelphia, Peregrine Systems, Google, Symbol Technologies, Rite Aid, Inso, Warnaco, Computer Associates International, Gemstar-TV Guide, and Tyco. ${ }^{128}$ As noted earlier, the flagrant disregard for the law by multiple companies across diverse industries prompted Judge Sporkin to ask, "Where were the lawyers?",29

\section{E. SOX Enforcement Era: 2002 through 2008}

These scandals incited public outrage, prompting a new era of sterner federal regulation of business, most notably in the form of the SarbanesOxley Act ("SOX") of 2002. ${ }^{130}$ In an effort to ensure that lawyers protected public investors by acting more as gatekeepers (or "cops") than, perhaps, as "entrepreneurs," Congress placed unprecedented scrutiny on the role and responsibilities of inside counsel, "essentially deputiz[ing] a public corporation's CLO [Chief Legal Officer] as a gatekeeper of ...

125. Grant McCool, US Judge Sentences Ex-Monster Counsel to Probation, REUTERS (Mar. 2, 2010), http://www.reuters.com/article/monsterworldwide-counselidUSN0218689420100302. A variety of companies issued employee stock options at an exercise price that was lower than the fair market value on the date the options were actually granted by backdating the grant to an earlier date when the market value was lower. Granting "in-the-money" options triggers a charge against earnings equal to the difference between the fair market value on the day of grant and the exercise price. Firms that backdated option grants committed accounting fraud when they failed to report this compensation expense. Catherine Fredenburgh, What's the Big Deal About Backdating Stock Options?, LAw360 (June 15, 2006, 12:00 AM ET), http://www.law360.com/articles/7017/what-s-the-big-deal-about-backdating-stock-options [perma.cc/6DGA-TDZ2].

126. Donald C. Langevoort, Getting (Too) Comfortable: In-house Lawyers, Enterprise Risk, and the Financial Crisis, 2012 Wis. L. REV. 495, 496 (2012).

127. Bagley \& Roellig, supra note 73.

128. Kim, supra note 55, at 985.

129. Guttman \& Sporkin, supra note 67.

130. Pub. L. No. 107-204, 15 U.S.C. $§ 7201$ et seq. (2003). 
national securities markets." ${ }^{131}$ These external changes impelled internal ones.

For example, Section 307 of SOX requires in-house counsel to report up the ladder material violations of law to the chief legal counsel or chief executive officer; if such individuals do not "appropriately respond," the attorney must report the violation to the audit committee of the board of directors. ${ }^{132}$ Section 307 also authorizes the attorney to disclose confidential information without the issuer's consent to the SEC in certain circumstances. ${ }^{133}$ Congress had faulted Enron's in-house counsel and outside lawyers for "displaying a lack of objective professional advice and oversight" 134 after they failed to report the accounting fraud perpetrated by Enron's senior management to the SEC. ${ }^{135}$ MassMutual Financial now annually sends a letter to all its outside counsel attaching its reporting-up policy and making it very clear that outside counsel are expected to report to the general counsel any issue they see where a company's lawyers or its other employees are violating the law. It further instructs outside counsel to report any such activity to the CEO and ultimately to the board if the general counsel or the CEO are involved.

Corporations responded to these stricter federal regulations by recruiting a new kind of general counsel, triggering a fundamental shift in the evolution of the position's function. The professional profile of general counsel shifted away from experience on Wall Street and in Silicon Valley to experience in Washington, D.C. and on Capitol Hill. ${ }^{136}$ Having, for example, an "ex-regulator or former federal prosecutor as the company's chief lawyer, it was reasoned, would neutralize potential enforcement issues before crises erupted."137 Corporations "required a general counsel

131. Kim, supra note 55.

132. 17 C.F.R. $§ 205.3($ b); Ahmed \& Farkas, supra note 46, at 866-67.

133. 17 C.F.R. $§ 205.3(d)(2)$; Ahmed \& Farkas, supra note 46, at 866-67.

134. James L. Sonne, Sarbanes-Oxley Section 307: A Progress Report on How Law Firms and Corporate Legal Departments Are Implementing SEC Attorney Conduct Rules, 23 GeO. J. Legal Ethics 859, 859 (2010).

135. Ahmed \& Farkas, supra note 46 , at 863.

136. Eichbaum, supra note 116 , at 48 .

137. Id. (including notable examples: "Steve Cutler, Gary Lynch, and Dick Walker, all former Directors of Enforcement of the SEC, [who] became general counsel of JPMorgan Chase, Morgan Stanley, and Deutsche Bank, respectively. David Aufhauser and Neal Wolin, both former general counsel at the Treasury Department, re-entered the private sector as general counsel of Hartford Financial Services and UBS. Former Justice officials Larry Thompson, Jim Comey, Jonathan Schwartz, Beth Wilkinson, and Ivan Fong became general counsel of PepsiCo, Lockheed Martin, Cablevision, Fannie Mae, and Cardinal Health. Other general counsel of major U.S. corporations who have significant prior experience with federal agencies include Larry Tu, Dell, Inc. (State Department); Paula Boggs, Starbucks (Army); and Judith Miller, Bechtel (Defense Department).”). 
who could proactively identify and defuse risk, and who knew how U.S. regulators thought and what they cared about." ${ }^{138}$ Counsel needed to understand and comply with new regulations and to prevent unethical corporate behavior.

These evolutionary shifts restored some of inside counsel's original, intended integrity and concern with the public good, but they by no means sparked the full transformation ${ }^{139}$ the profession needed, as evidenced by the ensuing subprime mortgage crisis and other scandals.

\section{F. The Subprime Mortgage Crisis and Massive Product Recalls Land Counsel and their Clients Back in the Drink: 2008 to the Present}

Triggering what some economists have dubbed the worst financial crisis since the Great Depression, ${ }^{140}$ leading banks knowingly sold billions of dollars of faulty subprime mortgages and mortgage-backed securities in the early aughts. This resulted in a series of criminal and civil actions against the responsible companies following highly publicized congressional investigations, federal administrative actions, and joint multistate-federal actions.

In reference to Citigroup's leveraged lending practices, Charles O. Prince III, former general counsel and then CEO of Citigroup, quipped in July 2007, "When the music stops, in terms of liquidity, things will be complicated. But as long as the music is playing, you've got to get up and dance. We're still dancing." 141 Months later, Citigroup had to write down its leveraged loan portfolio by $\$ 1.5$ billion. ${ }^{142}$

Even the storied multinational investment firm Goldman Sachs did not escape unscathed. In 2010, it agreed to pay $\$ 550$ million to the SEC - the largest settlement ever collected by the SEC from a Wall Street firm - to settle charges that Goldman committed securities fraud when it sold

138. Id.

139. See Robert C. Bird, Pathways of Legal Strategy, 14 Stan. J.L., Bus. \& Fin. 1, 12-13 (2008) (identifying five "pathways of corporate legal strategy": (1) avoidance, (2) compliance, (3) prevention, (4) advantage and (5) transformation); see also Robert C. Bird \& David Orozco, Finding the Right Corporate Legal Strategy, 56 MIT SLOAN MGMT. Rev. 81,82 (2014) ("The five, in order of least to greatest strategic impact, are: (1) avoidance, (2) compliance, (3) prevention, (4) value and (5) transformation.").

140. David Pendery, Three Top Economists Agree 2009 Worst Financial Crisis Since Great Depression; Risks Increase if Right Steps Are Not Taken, REUTERS (Feb. 27, 2009, 10:22am EST), http://www.reuters.com/article/2009/02/27/idUS193520+27-Feb2009+BW20090227 [perma.cc/E6LU-K5ZR].

141. Cyrus Sanati, Prince Finally Explains his Dancing Comment, N.Y. Times (Apr. 8, 2010, 2:04 PM), http://dealbook.nytimes.com/2010/04/08/prince-finally-explains-hisdancing-comment/?_r=0 [perma.cc/K66S-YGL3].

142. Id. 
derivative contracts based on subprime mortgages without disclosing that another Goldman client, who had taken a short position in the subprime market, had helped select the mortgage-backed securities on which the derivatives were based. ${ }^{143}$ Goldman also allegedly spread negative rumors about the Greek sovereign debt market while simultaneously serving as an adviser to the Greek government. ${ }^{144}$

Conduct by Goldman and other investment banks involved in the meltdown of the subprime mortgage market that began in 2008 contributed to the passage of the Dodd-Frank Wall Street Reform and Consumer Protection Act of 2010 ("Dodd-Frank"). ${ }^{145}$ In 2012, forty-nine state attorneys general and the attorney general of the District of Columbia partnered with the federal government in reaching a $\$ 25$ billion settlement with the five largest U.S. mortgage lenders-Bank of America, Ally Bank (formerly GMAC), JPMorgan Chase, Wells Fargo, and Citicorp-for their bad faith dealings with investors. ${ }^{146}$ Bank of America agreed in August 2014 to pay $\$ 17$ billion to settle similar allegations from the U.S. Department of Justice ("DOJ") in what is the largest settlement ever reached between the U.S. government and a single company. ${ }^{147}$ Approximately equivalent to the Bank's total profit over the past three years, the $\$ 17$ billion settlement still represents only a fraction of the staggering total $\$ 80$ billion the bank has spent on legal battles stemming from the financial crisis. ${ }^{148}$ In total since the crisis, the SEC has collected

143. U.S. Securities \& Exchange Commission, Goldman Sachs to Pay Record $\$ 550$ Million to Settle SEC Charges Related to Subprime Mortgage CDO (July 15, 2010), http://www.sec.gov/news/press/2010/2010-123.htm [perma.cc/74XT-824X]. The complaint is available at http://www.sec.gov/litigation/complaints/2010/comp-pr2010-59.pdf [perma.cc/P54H-VKD3]. See also Sewell Chan \& Louise Story, Goldman Pays $\$ 550$ Million to Settle Fraud Case, N.Y. TIMES, July 15, 2010, at B1 ("Goldman Sachs has agreed to pay $\$ 550$ million to settle federal claims that it misled investors in a subprime mortgage product ....").

144. See Joseph Stiglitz, The Fraught Road to World Financial Reform, INDEP. FIN. REV. (NZ), June 10, 2010 (“That Goldman Sachs executive saw himself as doing 'God's work' as his firm sold short products it created, or disseminated scurrilous rumors about a country where it was serving as an 'advisor,' suggests a parallel universe, with different mores and values.").

145. Pub. L. No. 111-203, § 929-Z, 124 Stat. 1376, 1871 (2010) (codified at 15 U.S.C. $\S$ $780)$

146. Daniel Fisher, Here's What's in the \$25 Billion Mortgage Settlement, Forbes (Feb. 9, 2012), http://www forbes.com/sites/danielfisher/2012/02/09/states-feds-to-announce-25billion-mortgage-settlement/ [perma.cc/WDK3-2ZQG].

147. Christina Rexrode \& Devlin Barrett, Bank of America to Pay $\$ 17$ Billion in Justice Department Settlement, WALl ST. J., Aug. 20, 2014, http://online.wsj.com/articles/bank-ofamerica-reaches-17-billion-settlement-1408560100 [perma.cc/MZ5Z-2H5Z].

148. See id. ("Bank of America has spent more than $\$ 60$ billion on legal woes stemming from the financial crisis, and the latest settlement would push the tab to close to $\$ 80$ 
more than $\$ 3.64$ billion in penalties, disgorgement, and other monetary relief from responsible companies on behalf of wronged public investors. ${ }^{149}$ This is in addition to the $\$ 115$ billion in legal fees U.S. banks have paid relating to the financial crisis. ${ }^{150}$

Persistent wrongdoing has not been confined to the financial sector. In 2007, Mattel had to recall 2 million toys with unsafe levels of leadtainted paint. Notwithstanding a renewed focus on public safety reflected in tougher product safety laws promulgated in 2008, ${ }^{151}$ Mattel continued to sell lead-tainted toys. ${ }^{152}$

The "new" General Motors that emerged from bankruptcy was clobbered by accusations that it had ignored potentially fatal safety issues related to its ignition switches for more than a decade. Since February 2014, General Motors has recalled 2.6 million vehicles due to faulty ignition systems linked to at least 124 deaths and almost 400 injuries, and it has paid $\$ 595$ million to the victims and their families. ${ }^{153}$ General Motors failed to issue vehicle recalls during the staggering ten-year period the automaker knew of the defects. ${ }^{154}$ This not only "threaten[ed] to undermine

billion.").

149. See generally U.S. Securities \& Exchange Commission, SEC Enforcement Actions Addressing Misconduct That Led to or Arose From the Financial Crisis, http://www.sec.gov/spotlight/enf-actions-fc.shtml [perma.cc/48Z6-B2JJ] (summarizing all of the money the SEC has collected from responsible companies).

150. See A Strong Start to the Earnings Season, CASEY DAily DisPatch (July 17, 2015), https://www .caseyresearch.com/articles/a-strong-start-to-earnings-season [perma.cc/L4P3XMY9] (containing a figure that represents fees paid through September 2014).

151. Consumer Product Safety Improvement Act of 2008, Pub. L. No. 110-314, 122 Stat. 3016 (2008). Among other things, the act banned lead levels above a certain amount and banned phthalates in children's products.

152. Press Release, Consumer Product Safety Comm'n, Mattel, Fisher-Price to Pay $\$ 2.3$ Million Civil Penalty for Violating Federal Lead Paint Ban, Penalty is Highest Ever for CPSC Regulated Product Violations (June 5, 2009), http://www.cpsc.gov/en/Newsroom/News-Releases/2009/Mattel-Fisher-Price-to-Pay-23Million-Civil-Penalty-for-Violating-Federal-Lead-Paint-Ban-Penalty-is-highest-ever-forCPSC-regulated-product-violations/ [perma.cc/Y29M-PSY8] ("The penalty settlement, which has been provisionally accepted by the Commission, resolves CPSC staff allegations that Mattel and Fisher Price knowingly (as defined in the Consumer Protection Safety Act) imported and sold children's toys with paints or other surface coatings that contained lead levels that violated a 30-year-old federal law.").

153. See Bill Vlasic, G.M. Chief Is Named Chairwoman, Affirming Her Leadership, N.Y. TimeS (Jan. 4, 2016), http://www.nytimes.com/2016/01/05/business/gm-chief-is-namedchairwoman-affirming-her-leadership.html [perma.cc/J4J6-KJFH] ("[T]he company admitted to selling millions of small cars with defective ignition switches that were later tied to at least 124 deaths").

154. See Jerry Hirsch, Embattled General Motors General Counsel Millikin To Retire, L.A. TiMES (Oct. 17, 2014, 11:08 AM), http://www.latimes.com/business/autos/la-fi-hy-gmlawyer-millikin-retires-20141017-story.html [perma.cc/GG3S-JWGH] ("The automaker 
the company's reputation for quality,"155 it also impeached its integrity. Michael Millikin, who became general counsel of General Motors in 2009 and retired in July 2015, denied knowledge of the ignition-switch problems even though other lawyers in his department were aware of them and had settled cases with confidentiality agreements to keep problems hidden. ${ }^{156}$ Plaintiffs have subpoenaed General Motors' chief outside counsel King and Spaulding to determine "who knew what, when."157 At a minimum, Millikin had failed to create a culture in which his in-house and external attorneys knew they were expected to report up to him any material legal or safety issues. ${ }^{158}$ Mary Barra, who took over as General Motors' CEO in January 2014, repeatedly apologized for "putting lives at risk in the company's cars" and "fir[ed] employees responsible for the decade-long delay in fixing the problem." ${ }^{159}$ In September 2015, General Motors agreed to pay a $\$ 900$ million criminal penalty to settle U.S. Department claims related to the defects. ${ }^{160}$ Barra reportedly told employees at a town hall meeting in the fall of 2015 that General Motors "still had work to do to

knew about the problem for at least a decade but waited until this year to start recalling the cars.").

155. Bill Vlasic \& Danielle Ivory, In Recall Blitz, G.M. Risks Its Reputation, N.Y. TimeS (June 30, 2014), http://www.nytimes.com/2014/07/01/business/gm-announces-vastexpansion-of-its-recalls.html [perma.cc/F36B-TD9P].

156. Hirsch, supra note 154.

157. General Motors and King \& Spalding have been accused of conspiring to commit fraud and "conceal a known safety defect by quietly settling death and injury cases rather than instituting a recall." Sue Reisinger, GM Plaintiffs Try Crime-Fraud Exception to Get Documents, CORP. COunSEL (June 15, 2015), http://www.corpcounsel.com/id=1202729304577/GM-Plaintiffs-Try-CrimeFraud-

Exception-to-Get-Documents [perma.cc/7F4F-9WT9]. Various documents have been subpoenaed but not produced as of June 2015. Id.

158. "'Whether general 'culture' issues are to blame is difficult, but the story of the Cobalt is one in which GM personnel failed to raise significant issues to key decision makers. Senior attorneys did not elevate the issue within the Legal chain of command to the General Counsel even after receiving the [redacted] evaluation in the summer of 2013 that warned of the risk of punitive damages because of a 'compelling[]' argument that GM had "essentially ... done nothing to correct the problem for the last nine years." ANTON R. VAlukas, Report to BoARD OF Directors of General Motors COMPANy REGARDing Ignition Switch ReCALls 1, 253 (May 29, 2014). Report is available on the NHTSA website at www.nhtsa.gov (enter "Valukas Report" in search box, then follow "[PDF] Valukas report on General Motors - Home National Highway ..." hyperlink.

159. Vlasic, supra note 153.

160. Nathan Bomey \& Kevin McCoy, GM Agrees to $\$ 900 M$ Criminal Settlement Over Ignition-Switch Defect, USA TODAY (Sept. 17, 2015, 6:37 p.m. EDT), http://www.usatoday.com/story/money/cars/2015/09/17/gm-justice-department-ignitionswitch-defect-settlement/32545959/ [perma.cc/CUQ6-HZGL]. The Justice Department indicated that individual employees could still be charged. Id. As of September 2015, General Motors had incurred more than $\$ 2$ billion in fines and penalties related to the faulty switches, exclusive of the cost to repair the recalled vehicles. Id. 
restore its reputation for quality and safety," accountability don't amount to much if you don't change your behavior."162 One analyst attributed her promotion to the additional rank of chair in January 2016 in part to how General Motors responded to her "initiatives to overhaul its culture after the ignition scandal." 163 The costly overhaul would not have been necessary had both General Motors' lawyers and its managers accepted responsibility for ensuring the safety of the company's products and acted promptly to address defects as soon as they became known instead of using confidential settlement agreements to hide them.

Similarly, by 2016, Japanese airbag manufacturer Takata had recalled almost 20 million vehicles due to faulty airbags, which can explode when deployed. ${ }^{164}$ The defects have resulted in at least eight deaths in the United States and more than one hundred serious injuries. ${ }^{165}$ Takata may have to recall millions more airbags unless it can prove that the propellant it uses is safe. ${ }^{166}$ A highly critical report published by the Senate Committee on Commerce, Science and Transportation in 2015 attributed Takata's delayed response to the defects in part to cost-saving measures, ${ }^{167}$ a charge Takata denied. ${ }^{168}$ The Committee also found the same types of failures of communication between the manufacturer's home office in Japan and operations in the United States (and Mexico, in the case of Takata) ${ }^{169}$ as contributed to Toyota's tardy response to complaints by Americans of "unintended acceleration." "The New York Times reported that Takata had manipulated airbag test results since at least $2000 .{ }^{171}$ The Times also

161. Id.

162. Id.

163. Vlasic, supra note 153.

164. See Danielle Ivory \& Hiroko Tabuchi, Takata Emails Show Brash Exchanges about Data Tampering, N.Y. TIMES (Jan. 4, 2016), http://www.nytimes.com/2016/01/05/business/ takata-emails-show-brash-exchanges-about-data-tampering.html [perma.cc/4WDT-GM2V] (detailing the recall).

165. Id.

166. Id.

167. See Comm. on Commerce, ScI. \& Transp., supra note 23, at 15 (noting that engineers in the Monclova, Mexico plant had identified quality issues as far back as 2001).

168. See Hiroko Tabuchi \& Danielle Ivory, Takata is Said to Have Stopped Safety Audits as a Cost-Saving Move, N.Y. TIMES (June 22, 2015), http://www.nytimes.com/2015/06/ 23/business/takata-is-said-to-have-stopped-safety-audits-as-cost-saving-move.html [perma.cc/5LPF-VA83] (reporting on Takata's response).

169. See Comm. On Commerce, ScI. \& TransP., supra note 23, at 15 (noting that engineers in the Monclova, Mexico plant had identified quality issues as far back as 2001).

170. See A RoAd Forward: The Report of the TOyota North AmERICAN Quality ADVISORY PANEL, 1, 4 (May 2011), http://www.safetyresearch.net/Library/Toyota_Quality_ Report.pdf [perma.cc/4G5Y-M6VP] (discussing the internal issues that led to the delayed Toyota recall of more than five million Toyota vehicles).

171. See Ivory \& Tabuchi, supra note 164 ("Takata's practice of manipulating airbag test 
quoted a January 2005 memo from Bob Schubert, a Takata airbag engineer, in which he told a colleague that he (Schubert) had been "repeatedly exposed to the Japanese practice of altering data presented to the customer." ${ }^{\text {"172 }}$ Citing Takata's alleged manipulation of safety testing data, the National Highway Traffic Safety Administration imposed a $\$ 70$ million fine in November 2015. ${ }^{173}$ On that same day, Honda Motor Company, which had been Takata's largest customer, dropped Takata as its airbag supplier, stating that Takata had "misrepresented and manipulated" its airbag testing data. ${ }^{174}$

In July 2015 the National Highway Traffic Safety Administration fined Fiat Chrysler Automobiles \$105 million for failing to fix problems in more than 11 million vehicles involved in 23 recalls since $2013 .{ }^{175}$ In the consent order, Fiat Chrysler admitted it had "failed to fix problems in three recalls and was slow or inadequate in notifying consumers and regulators of defects, including faulty ignition switches, suspension parts and fuel tanks." 176

One must ask, "What is going on here? Have companies accepted the payment of fines and damages as just a cost of doing business?" In the late 1970s and early 1980s, Ford Motor Company became a poster child for trading dollars for human lives and injuries when it failed to recall the Ford Pinto, which had a fuel tank that could explode if the vehicle were rearended at speeds as low as twenty miles per hour. ${ }^{177}$ In an infamous memo, Ford engineers had calculated that it would cost Ford about $\$ 137.5$ million to recall and fix the defective vehicles, but only about $\$ 49.6$ million to compensate victims injured or killed by the exploding gas tanks. ${ }^{178}$ Rejecting Ford's calculus, the jury awarded $\$ 2.5$ million in compensatory damages and $\$ 125$ million in punitive damages to punish Ford for its reprehensible conduct and deter other manufacturers from doing something similar. ${ }^{179}$ Such a high multiple of punitive to compensatory damages may

results dates to at least 2000 , just as the company began to introduce a new type of inflater.").

172. Id.

173. Id.

174. Id.

175. Amanda Bronstad, Plaintiffs Lawyers Plan Their Moves after Fiat Chrysler Fine, NAT'L L.J. (July 29, 2015), http://www.nationallawjournal.com/home/id= 1202733451629?slreturn=20150630103105[perma.cc/D92W-NJYF].

176. Id.

177. Grimshaw v. Ford Motor Co., 174 Cal. Rptr. 348, 360 (Ct. App. 1981).

178. W. Kip Viscusi, Corporate Risk Analysis: A Reckless Act?, 52 StAN. L. Rev. 547, 569-70 (2000). Design changes to enhance the integrity of the fuel tank system ranged from about $\$ 2.00$ per car to $\$ 10.00$ per car. Grimshaw, 174 Cal. Rptr. at 361 .

179. Grimshaw, $174 \mathrm{Cal}$. Rptr. at 358 . The punitive award was later reduced to $\$ 3.5$ million as a condition of denying Ford's motion for a new trial. Id. at 358-59. 
no longer be permitted since the U.S. Supreme Court held that "in practice, few awards exceeding a single-digit ratio between punitive and compensatory damages, to a significant degree, will satisfy due process." 180 We argue that in cases where a firm has knowingly engaged in unlawful conduct that endangered human health or safety that cap should not be imposed. Otherwise, managers are more likely to ignore their lawyers' advice and seek to justify their misconduct as "economically rational," given the chances of being caught and the likely monetary damages and fines. In any event, as discussed in Part V.D., such a calculus is shortsighted and underestimates the true cost of noncompliance.

The airline industry has been tainted by conflict-of-interest charges. In September 2015, Jeff Smisek, the CEO of United Airlines, resigned following an investigation into his relationship with David Samson, the then chair of the Port Authority of New York and New Jersey, which oversees the airport in Newark, New Jersey. United had begun flying a non-stop route (generally only about half full) between the Newark airport and a South Carolina airport about fifty miles from the Port Authority chair's weekend home at a time when United was working with the Port Authority to reduce the price of a new aircraft hangar United was building in Newark. ${ }^{181}$ United cancelled the flights after Samson resigned. Smisek, a graduate of Harvard Law School, received more than $\$ 4.8$ million in severance and may receive a bonus payout as well. ${ }^{182}$ In this case, we ask, "Where were the directors?"

Clearly the federalization of corporate governance in SOX, DoddFrank and related laws and regulations and the promulgation of tougher product safety standards have not had their intended effect of deterring corporate wrongdoing on a massive scale. Rather than looking outside the firm for more external attempts to require corporate compliance, we encourage firms and policy makers to look inward, at the role of both chief legal officers and managers in ensuring that firms create long-term value by operating with integrity.

Looking inward is especially important in light of the DOJ's recent prioritization of prosecuting responsible individual employees of a corporation, regardless of their rank, rather than simply the corporation

180. State Farm Mut. Auto. Ins. Co. v. Campbell, 538 U.S. 408, 425 (2003).

181. See Shawn Boburg, United CEO Quits Over Internal Probe of Airline's Relationship with Port Authority Ex-Chairman, NorTHJerSEY (Sept. 8, 2015, 5:16 PM), http://www.northjersey.com/news/united-ceo-quits-over-internal-probe-of-airline-srelationship-with-port-authority-ex-chairman-1.1405658?page=all [perma.cc/AJ5B-4Z7T] (discussing the chair's use of company airplanes to fly to his summer home).

182. Id. 
itself. ${ }^{183}$ Under the Federal Sentencing Guidelines for Organizations adopted by the U.S. Sentencing Commission, ${ }^{184}$ the maintenance of a meaningful voluntary compliance program is a mitigating factor that reduces the otherwise applicable fine. ${ }^{185}$ Unfortunately, certain companies have engaged in scapegoating, whereby lower-level employees are blamed for corporate wrongdoing while more senior managers, who were complicit or tacitly condoned behavior in violation of the company's compliance program, went scot free. ${ }^{186}$ On September 10, 2015, Deputy Attorney General Sally Quillian Yates announced that:

The rules have just changed. Effective today, if a company wants any consideration for its cooperation, it must give up the individuals, no matter where they sit within the company. And we're not going to let corporations plead ignorance. If they don't know who is responsible, they will need to find out. If they want any cooperation credit, they will need to investigate and identify the responsible parties, then provide all non-privileged evidence implicating those individuals. ${ }^{187}$

183. See Amie Tsang, Morning Agenda: Justice Department Sets Sights on Wall Street $\begin{array}{lllll}\text { Executives N.Y. Times } & \text { (Sept. } & 10, & \text { 2015), }\end{array}$ http://news.blogs.nytimes.com/2015/09/10/morning-agenda-justice-department-sets-sightson-wall-street-executives/?_r=0 [perma.cc/84CH-8YTA] ("After years of criticism that it has coddled Wall Street criminals, the Justice Department has prioritized the prosecution of individual employees and not just their companies ....”).

184. Congress created the U.S. Sentencing Commission in the Sentencing Reform Act of 1984, Pub. L. No. 98-473, 98 Stat. 1987 (1984) (codified in scattered sections of 18 U.S.C. \& 28 U.S.C. $\$ \S 991-998$ ). It is an independent agency in the judicial branch charged with establishing a fair and more uniform federal sentencing system for both individuals and organizations. Id. The Federal Sentencing Guidelines for Organizations went into effect in 1991. Ethics \& Compliance Initiative, FSGO: Federal Sentencing Guidelines for Organizations at 20 Years, http://www.ethics.org/?q=page/fsgo-federal-sentencingguidelines-organizations-20-yearshttp [perma.cc/3VAN-RH9G] (last visited Aug. 30, 2015). They are "designed so that the sanctions imposed upon organizations and their agents, taken together, will provide just punishment, adequate deterrence, and incentives for organizations to maintain internal mechanisms for preventing, detecting and reporting criminal conduct." United States Sentencing Commission, Guidelines Manual, §3E1.1 (Nov. 2013).

185. See id. at 502 ("The prior diligence of an organization in seeking to detect and prevent criminal conduct has a direct bearing on the appropriate penalties and probation terms for the organization if it is convicted and sentenced for a criminal offense.").

186. See William S. Laufer, Corporate Prosecution, Cooperation, and the Trading of Favors, 87 IowA L. REv. 643, 658-60 (2002) (warning that scapegoating can result in "selfdeception, denial of responsibility, and lack of repentance" as well as the "purchase" of the trappings of compliance just to impress regulators).

187. Dep't of Justice, Deputy Attorney General Sally Quillian Yates Delivers Remarks at New York University School of Law Announcing New Policy on Individual Liability in Matters of Corporate Wrongdoing (Sept. 10, 2015); see also U.S. Dep't of Justice, Memorandum for the Assistant Attorney General, Antitrust Division, et al. on Individual 


\section{LEGAL AND STRATEGIC ASTUTENESS}

Legal astuteness is the baseline level of legal literacy that enables nonlawyer managers to effectively communicate with lawyers regarding the legal and ethical issues that increasingly affect business success or failure. ${ }^{188}$ Without legal astuteness, the common moral discourse between lawyers and non-lawyers, if any, is inadequate, making it more likely that counsel will indeed need to forfeit their seat at the senior executive table to preserve the independent integrity of their office.

Legal astuteness is a valuable dynamic capability ${ }^{189}$ and may be a source of sustained competitive advantage under the resource-based view of the firm. ${ }^{190}$ Legal astuteness:

requires (1) a set of value-laden attitudes about the importance of law and ethical behavior to firm success, (2) a proactive approach to regulation and risk, (3) the ability to exercise informed judgment when managing the legal and business aspects of the firm, and (4) context-specific knowledge of the law and the appropriate use of legal tools. ${ }^{191}$

Moreover, a TMT cannot be legally astute without strategically astute lawyers. ${ }^{192}$ Strategic astuteness:

requires (1) a set of value-laden attitudes; (2) a proactive approach to business opportunities and threats, including not just regulatory and legal risk but also market and competitive challenges, risks, and opportunities; (3) informed judgment; [and] (4) context-specific knowledge of management, business, the law, and the appropriate use of both managerial and legal tools. ${ }^{193}$

Accountability for Corporate Wrongdoing (Sept. 9, 2015), http://www.justice.gov/dag/file/769036/download [perma.cc/2PK7-WEDH] (detailing the steps involved in investigating corporate misconduct).

188. Bagley, supra note 68.

189. Bagley, supra note 73. The dynamic capabilities approach explains how certain firms create competitive advantage in a "Schumpeterian world of innovation-based competition, price/performance rivalry, increasing returns, and the 'creative destruction' of existing competencies." David J. Teece, Gary Pisano \& Amy Shuen, Dynamic Capabilities and Strategic Management, 18 STRAT. MGMT. J. 509, 509 (1997) (internal citation omitted) (quoting Joseph A. SCHUMPETER, THEORY OF ECONOMIC DEVELOPMENT (1934)).

190. See Constance E. Bagley, What's Law Got to Do with It? Integrating Law and Strategy, 47 AM. Bus. L.J. 587, 592 (2010) (legal astuteness is "the ability of managers to communicate effectively with counsel and to work together to solve complex problems and leverage the resource advantages of the firm ....").

191. Bagley, supra note 73 , at 8 .

192. See Bagley \& Roellig, supra note 73 , at $45-66$.

193. BAGLEY, supra note 71. 


\section{A. Value-Laden Attitudes}

Legal and strategic astuteness require a set of value-laden attitudes about the importance of law and ethical behavior to economic success. As Jim Metcalf, then President of USG Corporation stated, "It's important to remember who you are and where you're from. Then you fight like hell to be good stewards." 194 It is essential for the leadership of a firm to establish and enforce explicit and implicit expectations for all employees, beginning with senior executives. Especially with respect to corporate values, "management communicates as much by what it doesn't do or say as by what it says and does. In fact, behavioral forms of communication are apt to have more credibility than spoken or written forms." 195 Accordingly, it is not enough for corporations simply to state their corporate values; their leaders must practice them and hold accountable those who fail to act in accordance with them. As former General Electric General Counsel Benjamin Heineman explains:

The stirring call for performance with integrity at the large company meeting can be eroded by the cynical comment an executive makes at a smaller meeting, by the winks and nods that implicitly sanction improprieties, by personal actions (dishonesty, lack of candor) that contradicts [sic] company values. ${ }^{196}$

"Creative compliance," defined by Terrell as "complying with the letter of the law but defeating its spirit and purpose," 197 as well as capitalizing on unintended legal loopholes, ${ }^{198}$ rub against the grain of the legally astute culture. Even if an action is not inherently unlawful, it may make subsequent unlawful action more likely to occur.

These value-laden attitudes include an understanding of the intertwined nature of business and ethical interests; as already noted, "business decisions consist of continuous, interrelated economic and moral

194. Constance E. Bagley \& Eliot Sherman, USG Corporation (C), Harvard Business School Case No. 807-121, at 8 (2007).

195. PhiliP T. Drotning, Organizing the Company for Social Action, in The Unstable Ground: Corporate Social Policy in a Dynamic Society 260 (S. Prakash Sethi ed., 1974).

196. Benjamin Heineman, Jr., Avoiding Integrity Landmines, 85 HARV. Bus. REV. 100, 102 (2007).

197. Timothy P. Terrell, Professionalism on an International Scale: The Lex Mundi Project to Identify the Fundamental Shared Values of Law Practice, 23 EMORY L. REV. 469, 536 (2009).

198. See Daniel T. Ostas, Legal Loopholes and Underenforced Laws: Examining the Ethical Dimensions of Corporate Legal Strategy, 46 AM. Bus. L.J. 487, 487 (2009) (discussing legal loopholes and underenforced laws). 
components." 199 When these interests appear to conflict, counsel and business leaders "should keep trying to reframe issues and refine tactics until they are satisfied that the firm's legitimate business objective of 'winning' in the marketplace is being advanced in an effective, legal, and above board manner." ${ }^{200}$ Managers must consider not only what the firm can do but also what it should do. ${ }^{201}$ Former CEO of Johnson \& Johnson ("J\&J") Ralph Larson captured this sentiment when he responded to the question of whether he wanted $\mathrm{J} \& \mathrm{~J}$ to maximize shareholder value or be a good corporate citizen by answering, "Yes.", ${ }^{202}$ He rejected what he termed "the tyranny of the "or'.",203 When asked which qualities were most important for successful leaders, Berkshire Hathaway's Warren Buffet responded, "'Integrity, intelligence and energy. Without the first, the other two will kill you.'"

Victor Tettmar, the managing partner of Bond Pearce, called general counsel the "guardian of moral capital." 205 We argue that general counsel must be "a" guardian of moral capital who empowers the top management team to share that responsibility. Both counsel and managers can better protect that capital when they embrace the idea that "the moral aspects of choice" are the "final component of strategy."206

\section{B. Proactive Approach}

An intrinsically valuable practice, ${ }^{207}$ taking a proactive approach toward business and legal issues is a hallmark of legally astute top management teams: "Business corporations do not have legal problems. They have business problems where legal considerations may be more or

199. Diane L. Swanson, Addressing a Theoretical Problem in Reorienting the Corporate Social Performance Model, 20 ACAD. MGMT. Rev. 43, 51 (1995).

200. Bagley \& Roellig, supra note 73.

201. C. Roland Christensen et Al., Business Policy: TeXT And Cases 121 (6th ed. 1987).

202. Bagley \& Page, supra note 69 , at 913.

203. Id.

204. See Ibolya Balog, Ethics on their Shoulders: Boards Bear the Burden, AcCT. TODAY (Nov. 27, 2006), http://www.accountingtoday.com/ato_issues/2006_21/226031.html [perma.cc/PZ23-6XYH] (Buffett took over as head of investment bank Salomon Brothers after its illegal rigging of Treasury auctions almost destroyed the venerable bank. He gave employees his home phone number in Omaha, Nebraska, and asked them to call him directly if they observed any improper behavior); see also MICHAEL LEWIS, LIAR's POKER (1989) (telling the story of the author's four years at a Wall Street investment firm).

205. Rebecca Lowe, Compliant Counsel, 8(2) In-House PersPective 13, 14 (2012).

206. CHRISTENSEN ET AL., supra note 201, at 578.

207. See generally Teece et al., supra note 189 (discussing how firms achieve and sustain competitive advantage). 
less important, depending on the specific circumstances."208

Business leaders who view the "law purely as a constraint, something to comply with and react to rather than to use proactively, will miss opportunities to use the law and the legal system to sense and seize opportunities and thereby increase the firm's realizable value."209 Additionally, they will lose the value strategically astute lawyers provide the firm. ${ }^{210}$ Instead, legally astute business leaders acknowledge inside counsel's "right and responsibility to insist upon early legal involvement in major transactions." 211 Failing to do so prevents counsel from actively participating in the creation and capture of firm value. "[T]he later a lawyer is brought into the planning of a transaction, the more likely it is that the lawyer will have to say 'no.' Anticipating this, business managers may provide counsel with a skewed set of facts in hopes of improving the likelihood of receiving the go-ahead."212

Jonathan Anschell, General Counsel at CBS Television, recounted the difficulty of finding lawyers who do not walk into every meeting on a new venture saying, "“Are you sure you want to do this? It's very risky.",213 "'What they don't seem to understand,' Anschell said, 'is that we have no choice but to move forward. These markets are fluid, they're changing all the time and we can't afford to be hanging back waiting for the uncertainties to shake out. What we need are lawyers who know how to think about how to manage risk, not avoid it.",214

\section{Exercise of Informed Judgment}

Managing risk and being able to sense and seize opportunities require the exercise of informed judgment:

Law is not an exact science-legal rules are not applied formulaically. Seemingly minor changes in facts can result in dramatically different legal outcomes. Often, there is no clear precedent to serve as a guide. Dealing effectively with the uncertainties inherent in many decisions having legal aspects

208. Marshall B. Clinard \& Peter C. Yeager, Corporate Crime 20 (1980).

209. BAGLEY, supra note 71.

210. Bagley \& Roellig, supra note 73.

211. Chayes \& Chayes, supra note 86, at 281.

212. Constance E. Bagley \& Mark Roellig, General Counsel: Strategic Partners or Hired Guns?, in EUROPEAN COMPANy LAWYERS ASSOCIATION, COMPANy LAWYERS: INDEPENDENT BY DESIGN at 115 (Philippe Coen \& Christophe Roquilly eds., 2014), http://www.ecla.org/files/files/Profession/document1.pdf [perma.cc/QBQ2-MAQ7].

213. Quoted in Gillian K. Hadfield, Legal Infrastructure and the New Economy, $8 \mathrm{I} / \mathrm{S} \mathrm{J}$. L. POL'Y FOR INFO. SOC'Y 1, 4 (2012).

214. Id. 
requires the exercise of informed judgment. Legally astute managers - even those with formal legal training - do not purport to advise themselves on legal matters of importance. They appreciate the importance of selecting a true counselor at law who combines knowledge of the black-letter law with judgment and wisdom. As Yale Law School Dean Anthony T. Kronman (1995) explained, wisdom is more than technical skill; it is the capacity to offer deliberative advice - that is, to go beyond merely supplying whatever means are needed to achieve the client's goals and to deliberate with the client about the wisdom of the client's ends. ${ }^{215}$

"Certain courses of action may be legal but not wise."216

We define good judgment in the corporate setting as the ability to make effective, productive decisions and to take actions in multidimensional settings that are aligned with the legitimate business objectives. It requires the decision maker and advisor to identify what is important for all constituencies and to think through all the implications of the proposed action as well as the consequences of not acting. The participants need to gather the appropriate information to understand the issue at hand and decide whether external input is necessary for an informed decision, recognizing that the time and cost of obtaining further information may outweigh the benefits. Thus, one should not call meetings just for the sake of having a meeting.

It is important to listen to, evaluate and integrate often conflicting views from diverse participants before taking action. Integration requires the identification of trends, patterns, problems, and opportunities and the ability to make connections between what may at first appear to be different or unrelated issues or facts. The participants need to critically evaluate the goals, obstacles, likely responses, and proportionality of risks, costs, and benefits of the proposed course of action. This includes deciding what weight to put on the possibilities/potential outcomes and facts. It also requires knowing what is ethically and societally right and wrong, what is acceptable and what is not.

The participants must avoid acting on impulse but work together to ensure that the proposed action or advice is timely, balancing the degree of uncertainty and ambiguity as well as the magnitude of the risk and the opportunity. It is also important to make sure that the proposed action will actually solve the issue and not just "kick the can down the road." It is also critical to ensure that the proposed solution can be efficiently implemented in a timely, cost-effective, and ethical manner. The participants should

215. Bagley, supra note 68, at 381 (citing KronMAn, supra note 120, at 132-33).

216. Id. at 381 . 
strive to keep self-interest and recognition out of the equation: the right, difficult-to-sell solution is a bigger personal and corporate win than the easy, short-term personal gain. Finally, it is critical to know when and to whom to escalate a decision.

We posit that it may not be possible to teach good judgment, but it certainly is possible to practice exercising it. In the class "Introduction to In-House Practice of Law," taught by co-author Roellig at the University of Colorado Law School, ${ }^{217}$ Roellig uses business-school type case studies based on real fact patterns to tee up the discussions. ${ }^{218}$ The lead author has worked with in-house counsel in firms as diverse as MassMutual, Microsoft, CVS Health, and Prudential to design and present in-house training programs utilizing customized case studies that require the participants to practice exercising good judgment.

\section{Context-Specific Knowledge of the Law and Business and the Application of Legal and Managerial Tools}

As already noted, legal astuteness is the baseline level of legal literacy necessary for non-lawyer managers to effectively communicate with lawyers on the legal issues that increasingly affect business objectives. ${ }^{219}$ Legal literacy includes context-specific knowledge of the law and the appropriate application of legal tools. ${ }^{220}$ Similarly, strategically astute lawyers must be business savvy, familiar with at least the basics of accounting, corporate finance, negotiation, business planning, and competitive strategy. One manager complained:

Our lawyers just don't know what we do, how a business like this works. There's a massive DNA gap. I want lawyers who will come spend time here, getting to know how this business works, what we need and what we don't. I have a hard time getting outside counsel to take up my offer. ${ }^{221}$

The trust that managers and lawyers foster by regularly working together as a team is a firm-specific relationship ${ }^{222}$ that "cannot be readily

\footnotetext{
217. See Course Descriptions, COLORADO LAw, http://lawweb.colorado.edu/courses/courses.jsp?show=EK\&sortBy=TITLE [perma.cc/RXD5-5GGT] (last visited Jan. 30, 2016) (Colorado Law offering "Introduction to In-House Practice of Law" to its students).

218. This course is discussed further in Part VI.

219. Bagley, supra note 68.

220. Id.

221. Hadfield, supra note 213, at 4.

222. Jay B. Barney \& Mark H. Hansen, Trustworthiness as a Source of Competitive Advantage, 15 STRATEGIC MGMT. J. 175 (1994).
} 
recreated when a lawyer or manager leaves to join another firm."223 This teamwork also enhances the firm's "ability to sense the need to reconfigure the firm's asset structure and to accomplish the necessary internal and external transformation." 224 For example:

[I]n what Warren Buffett called "the most successful managerial performance in bankruptcy I've ever seen," USG Corporation, manufacturer of Sheetrock ${ }^{\circledR}$ wall board and other building materials, successfully shed its asbestos liability pursuant to an orchestrated strategy that combined (1) filing for bankruptcy under Chapter 11 so it could obtain a "channelling injunction," whereby the plaintiffs suing for asbestos-related disease would be required to seek redress solely from a dedicated trust funded by USG and approved by 75 percent of the claimants; (2) lobbying for federal legislation to create a multi-firm fund for the payment of asbestos personal injury claims in accordance with accepted medical standards for determining the existence and severity of asbestos-related disease; (3) litigating dubious claims; (4) a human resource strategy that valued both factory workers and upand-coming managers; (5) transparency with both investors and employees; (6) a reputation for reliability and honest dealing with suppliers, customers, and employees; and (7) the ability to shift resources from primarily manufacturing Sheetrock $®$ and its other building materials to distributing other firms' products as well. USG emerged from bankruptcy five years after filing with a channelling injunction in effect pursuant to a reorganization plan that was approved by $98 \%$ of the asbestos claimants and a shareholder committee led by Warren Buffett, whose holding company Berkshire Hathaway owned about 15 percent of USG's stock and back-stopped a $\$ 1$ billion rights offering, with all debts paid in full with default interest, shareholder equity intact, and more than a 50 percent increase in revenues. Although USG CEO Bill Foote conducted this "orchestration" and played a critical role lobbying for changes in the law, USG's success would not have been possible but for his own personal knowledge of law and legal tools, and his close relationship with GC [General Counsel] Stan Ferguson and other in-house lawyers along with the outside lawyers who helped litigate the asbestos claims and advised on the bankruptcy proceedings. ${ }^{225}$

223. Bagley, supra note 68.

224. Teece et al., supra note 189 , at 520.

225. BAGLEY, supra note 71 (citations omitted). 


\section{E. Partnership of Legally Astute Managers with Strategically Astute Lawyers}

Managers cannot be legally astute unless they are advised by strategically astute lawyers who understand their business. Similarly, it is very difficult, if not impossible, for a lawyer to be strategically astute unless his or her client is legally astute. Otherwise, the communication barriers will most likely prevent effective collaboration.

Strategically astute counsel and legally astute managers form what Kim Clark and Steve Wheelwright call "heavyweight teams," comprising managers and in-house lawyers. ${ }^{226}$ Unlike representatives governed by Graham Allison's notion of "where you stand depends on where you sit,"227 members of heavyweight teams do not just represent their functional group. Instead, they act as general managers with responsibilities for the success of the entire project. PepsiCo CEO Indra Nooyi echoed this sentiment when she explained that "we can't afford this separation of church and state," 228 whereby lawyers are satisfied with drafting perfect documentation for a flawed deal.

Strategically astute counsel help the managers craft the firm's value proposition and define the activities in the value chain, keeping legal and ethical as well as business imperatives "top of mind." Both strategically astute lawyers and legally astute managers recognize that business success and ethical and legal behavior complement, rather than oppose, each other. Rather than viewing the law as a constraint, legally astute top management teams use the law and legal and managerial tools to increase realizable value, marshal resources, and manage risk - both legal and business.

\section{General COUNSEl AS StRATEgic PARTNER Not HiRED GuN OR COP}

Although many of the entrepreneurial tendencies revealed by Nelson and Nielsen undoubtedly contributed to systemic corporate malfeasance at Enron, WorldCom, and other former high flyers, and major legal lapses at Bank of America, Citicorp, General Motors, and Barclays, we do not

226. Kim B. Clark \& Steven C. Wheelwright, Organizing and Leading "Heavyweight" Development Teams, CAL. Mgmt. Rev., Winter 1992, 9, 9.

227. See generally, Graham Allison \& Philip Zelikow, Essence of Decision: The CubAn Missile CRISIS 307, 325-47 (2d ed. 1999) (explaining that the recommendations of key decision makers involved in the Cuban missile crisis were highly correlated with their functional responsibilities, with, for example, the Secretary of Defense recommending a military response and the Secretary of State recommending negotiation).

228. BAGLEY, supra note 71 , at 380 . 
believe that a degree of entrepreneurialism in general counsel is per se bad, just as we do not believe that solely being the cop is per se good. Effective counsel do not presume to act fully independently of their business partners. If they did, then they would quickly become irrelevant, as managers conclude that it is indeed "better to ask forgiveness than permission." Instead, strategically astute counsel exercise informed judgment in the course of helping drive business success and take professional pride in avoiding the potential pitfalls of becoming too "comfortable," engaging in a "process of collective rationalization," or potentially assuming improper, irrational risk. ${ }^{229}$ We submit that general counsel should be both an active participant in the creation and capture of firm value as well as a trusted counselor-what we call the "strategic partner." However, while the strategic partner engages in entrepreneurialism, he or she does so in a crucially different way from Nelson and Nielsen's entrepreneurial lawyer. Unlike the entrepreneurial lawyer, who kowtows to the prerogatives of the top management team, a strategically astute counsel never engages in entrepreneurialism at the expense of his or her overriding professional duty and responsibility to the owners of the enterprise and the legal system to promote compliance with both the letter and the spirit of the law.

To say that general counsel should entirely eschew entrepreneurialism is an extreme that amounts to a "fetishization" of entrepreneurialism in the same way certain scholars have arguably overemphasized independence concerns of general counsel in the wake of massive corporate malfeasance-what Usha Rodrigues coined the "fetishization" of independence. ${ }^{230}$ Fetishization "transform[s] an essentially negative quality - [here] lack of ties to the corporation - into an end in itself., ${ }^{231}$ It is a shortsightedness to ignore, Simmons and Dinnage argue, the real value general counsel can generate by using these ties to the corporation, which may even outweigh the "risk and probabilities associated with conflicts." 232

The strategic partner recognizes that business pursuits must satisfy the firm's financial, legal, and ethical obligations. Put another way, the strategic partner continually refocuses business issues toward a consideration of means together with their ends, asking not only whether the ends are achievable but also whether the ends themselves are right. This approach is based on Dean Kronman's lawyer-statesman ideal: true counselors "deliberate, for and with their clients, about the wisdom of their

229. Langevoort, supra note 126, at 496.

230. Usha Rodrigues, The Fetishization of Independence, 33 J. CORP. L. 447, 447 (2008).

231. Id.

232. Omari Scott Simmons \& James D. Dinnage, Innkeepers: A Unifying Theory of the In-House Counsel Role, 41 SETON HALL L. REV. 77, 91-92 (2011). 
clients' ends, as opposed simply to supplying them with the legal means for realizing their desires."233 "A lawyer whose only responsibility is to prepare the way for ends that others have already set can never be anything but a deferential servant." ${ }^{\text {"234 }}$ The lawyer-statesman acts "as a kind of buffer between the illegitimate desires of his client and the social interest."235 Such an individual "represents [both] the client before the legal system," as well as the "legal system to the client.","36

Yet, is the lawyer-statesman's ethical burden too heavy for counsel to bear when they are also expected to serve on a corporation's top management team ("TMT")? IBM general counsel Robert Weber believes so, calling it an untenable "millstone" that requires counsel to forfeit their seat at the senior executive table. ${ }^{237}$ We respectfully disagree. General counsel can and should be both a senior executive and a corporate conscience, but counsel cannot be the sole corporate conscience. ${ }^{238}$ If counsel are, they will likely forfeit their seat at the senior executive table, as Weber predicts. This is because the other senior executives may not be willing to do what it takes to ensure that legality and ethics are not sacrificed at the altar of short-term profits, a risk that is exacerbated when executive compensation is tied to stock performance without proper regard for how the profits were generated.

Strategically astute counsel will therefore work with the other members of the TMT to establish a culture wherein all employees, but especially senior executives, recognize that meeting legal and ethical expectations is essential to enduring business success. The general counsel is, as a result, able to uphold a high ethical standard without fear of losing a seat at the senior executive table because he or she is but one in a collection

233. Kronman, supra note 120, at 133; see also Deborah Hussey Freeland, Recovering the Lost Lawyer, 2014 AM. BAR Ass'N J. PROF. LAW. 1 (2014) (discussing the disappointing reality that lawyers are striving to become task-proficient rather than developing the skills for intellectual and affective deliberation).

234. KRONMAN, supra note 120 , at 15.

235. Talcott Parsons, A Sociologist Looks at the Legal Profession, in ESSAYS IN SOCIOLOGICAL THEORY 384 (rev. ed. 1954).

236. Robert Gordon, Corporate Law Practice as a Public Calling, 49 MD. L. REv. 255, 255 (1990).

237. Robert Weber, Is the GC the Conscience of the Company? Maybe Not; IBM's general counsel explains why in-house lawyers aren't (and shouldn't be) the conscience of their companies., CORP. COUNSEL (Jan. 24, 2013), http://www.corpcounsel.com/id=1358699364123/Is-the-GC-the-Conscience-of-theCompany-Maybe-Not? [perma.cc/6D8M-UWLF].

238. Benjamin Heineman, Jr., General Counsel Are One Conscience of the Company; A Response to IBM's Robert Weber, CORP. COUNSEL (Jan. 24, 2013), http://www.corpcounsel.com/id=1202585457251/General-Counsel-are-One-Conscience-ofthe-Company [perma.cc/HXK9-A9CU]. 
of corporate consciences working in the C Suite.

Finally, to ensure that outside counsel obtain accurate and unbiased information regarding legal matters raised by the business leaders or the inhouse lawyers, we believe that managers should be empowered to speak directly with outside counsel, especially when the question at issue was internally blessed by in-house counsel. In such a situation, the general counsel and the responsible manager should ensure that the outside firm is truly independent to avoid the type of cooption that occurred when the audit committee at Enron asked outside counsel Vinson \& Elkins to opine on the legality of the very same special purpose entities that Vinson \& Elkins had helped create. ${ }^{239}$ In annual meetings with its key outside counsel, the general counsel of MassMutual Financial makes clear the expectations of its outside counsel to speak directly to the CEO, or the board if appropriate, if they have concerns regarding the pursuit of a particular business or legal approach.

Figures 1 and $2^{240}$ compare the reactive approach to legal issues followed by many firms who bring in outside counsel on an episodic basis with the type of ongoing communication that facilitates proactive advice from not only in-house but also outside counsel. Although the general counsel is usually responsible for managing legal spending and will, in most cases, decide when to bring in outside counsel and will often be the primary (if not, only) contact with outside counsel, if the in-house counsel has participated in a decision being challenged, then the responsible managers or board members should ensure that there is neither the reality nor appearance of conflict of interest. For example, if the general counsel has engineered the process by which an employee who subsequently claims discrimination was terminated, the employee's claims should be evaluated by independent counsel empowered to discuss the matter with not only the general counsel but also the managers involved. Otherwise, the enterprise could be put at undue risk by an in-house lawyer attempting to bury his or her own mistake. At MassMutual Financial, there have been occasions where the general counsel has requested the CEO to receive advice or confirmation directly from outside counsel, with no involvement by him, when he was personally involved in the particular underlying decision under review.

239. In re Enron Corp. Sec. Derivative \& ERISA Litig., 235 F. Supp. 2d 549, 658 (S.D. Tex. 2002) (finding that among the allegations against Vinson \& Elkins, Enron's outside general counsel, in the Enron litigation was that "Vinson \& Elkins provided advice in structuring virtually every Enron off-balance sheet transaction and prepared the transaction documents, including opinions, for deals involving ... vehicles used to defraud investors and the securities markets.").

240. BAGLEY, supra note 71, at 226. 
FIGURE 1: REACTIVE APPROACH TO LEGAL ISSUES

Conventional Approach

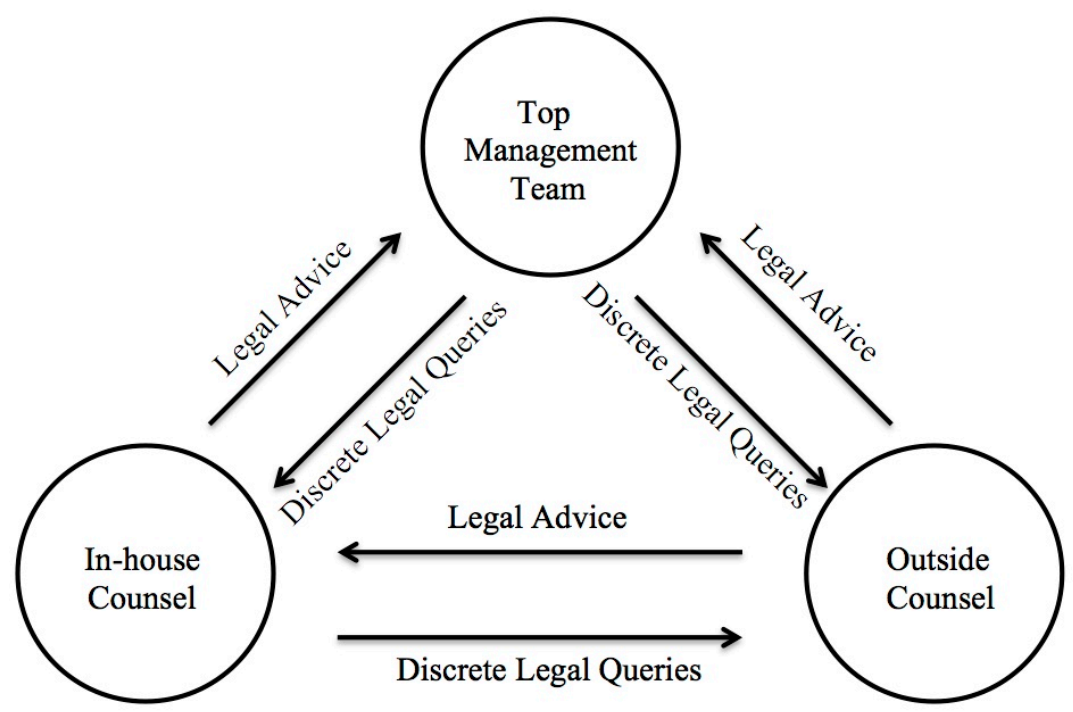

FiguRE 2: LEGALLy ASTUTE APPROACH TO LAW AND MANAGEMENT

Legally Astute Approach

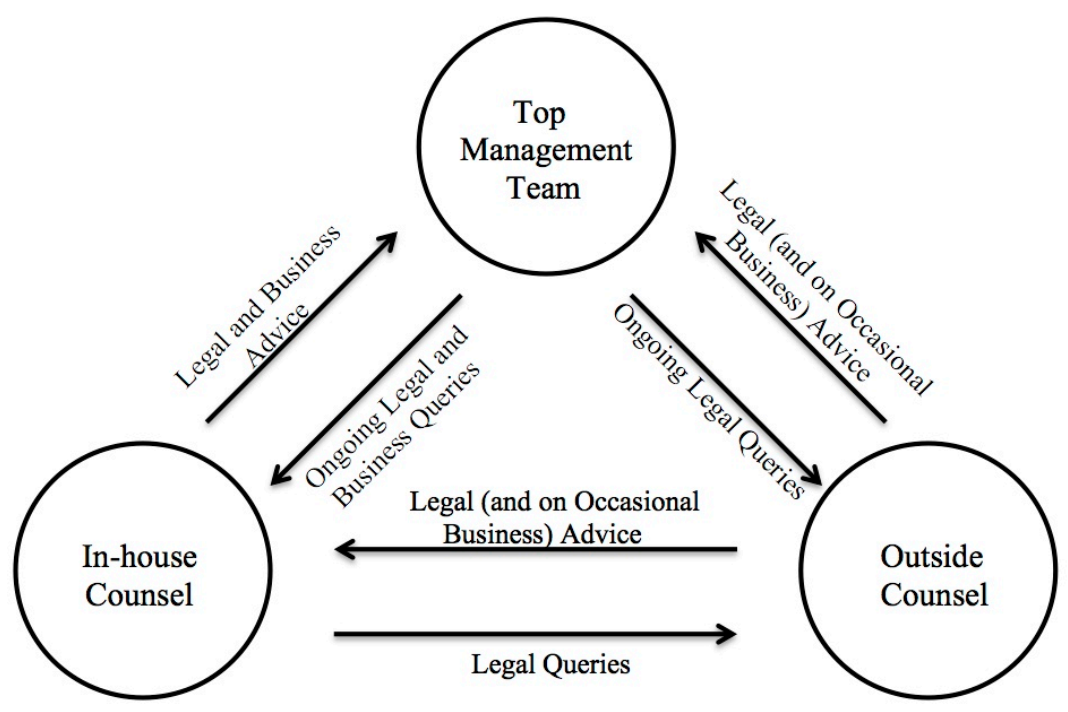




\section{The VAlUE of Legal AstUteness}

Legal astuteness is a valuable dynamic capability ${ }^{241}$ and may be a source of sustained competitive advantage under the resource-based view of the firm. ${ }^{242}$ Legal astuteness captures the strategic spirit of the entrepreneurial lawyer shaped by the legal and ethical imperatives of the lawyer-statesman ideal, ultimately optimizing the value counsel and, in turn, the entire top management team, can add to the firm. Specifically, legally astute top management teams can (1) use formal contracts as complements to relational governance to reduce transaction $\operatorname{costs}^{243}$ and strengthen relationships, (2) protect and enhance the realizable value of knowledge assets and other firm resources, (3) use legal tools to create valuable options, (4) practice "strategic compliance management" ${ }^{244}$ and thereby both promote legal compliance and enhance the firm's ability to convert regulatory constraints into opportunities, and (5) help shape the regulatory environment. ${ }^{245}$

\section{A. Using Contracts to Strengthen Relationships}

A famous study by Stewart Macaulay ${ }^{246}$ found that written contracts:

were often highly standardized documents that were largely confined to the drawer once drafted by the legal department then rarely consulted to resolve disputes. The parties' obligations were often adjusted without reference to the terms of the original contract and breaches were resolved without litigation or litigation threats. When problems arose, parties would find a solution 'as if there [had] never been any original contract' (Macaulay 1963). ${ }^{247}$

241. The dynamic capabilities approach explains how certain firms create competitive advantage in a "Schumpeterian world of innovation-based competition, price/performance rivalry, increasing returns, and the 'creative destruction' of existing competencies." Teece et al., supra note 189 , at 509 .

242. Bagley, supra note 68.

243. Oliver E. Williamson, Markets and Hierarchies: Analysis and Antitrust IMPLICATIONS (1975).

244. BAGLEY, supra note 71.

245. Bagley, supra note 68; BAGLEY, supra note 71.

246. Stewart Macaulay, Non-Contractual Relatives in Business: A Preliminary Study, 28 AM. Soc. Rev. 55, 64 (1963).

247. Iva Bozovic \& Gillian K. Hadfield, Scaffolding: Using Formal Contracts to Build Informal Relations to Support Innovation (Feb. 25, 2015), http://works.bepress.com/cgi/viewcontent. cgi?article=1055\&context=ghadfield [perma.cc/4Z94-EJRR]. 
Kent Walker, General Counsel of Google, and others have "bemoaned the difficulty of reducing the reams of wasted paper and effort in managing the company's contract relationships." 248

'Never, in ten years,' he [Walker] said, 'has a dispute ever turned on the precise language of a non-disclosure agreement. Yet we still spend lots of time dickering about these things.' In other areas, Walker has tried to bring some rationality to the amount of paper needed. 'But I send them the two pages I think we need, and they chuckle and send back ten or more.' And how, he wonders, can he give his legal teams the right incentives in contracting to recognize that sometimes too much legal wrangling or risk-aversion leads to lost or less valuable deals? ${ }^{249}$

We submit that the solution for Walker's problem with properly incentivizing lawyers is having legally astute managers actively involved in the negotiations and drafting of the contract. Although contracts are negotiated and enforced "in the shadow of the law," contracts with trust-building reduces the likelihood that disputes will have to be resolved via the court system.

Some contend that insisting on formal contracts, as opposed to taking someone at their word, signals distrust and thereby encourages opportunistic behavior. ${ }^{251}$ North and Weingast posit the opposite: contracts and other institutional assets "do not substitute for reputation-building and associated punishment strategies, but complement them."252 The process of contracting can help companies establish healthy, valuable business relationships by building social ties between the parties and clarifying their

248. Hadfield, supra note 213 , at 3.

249. Id. (quoting Kent Walker, the General Counsel at Google).

250. See Robert H. Mnookin \& L. Kornhauser, Bargaining in the Shadow of the Law: The Case of Divorce, 88 YALE L. J. 950, 997 (1979) (noting that "[i]ndividuals in a wide variety of contexts [beyond family law] bargain in the shadow of the law" and that "the preferences of the parties, the entitlements created by law, transaction costs, attitudes toward risk, and strategic behavior will substantially affect the negotiated outcomes").

251. Sumantra Ghoshal \& Peter Moran, Bad Practice: A Critique of the Transaction Cost Theory, 21 ACAD. MGMT. Rev. 13,24-27 (1996); see also Macaulay, supra note 246, at 164 (discussing non-contractual relations and communication).

252. Douglass C. North \& Barry R. Weingast, Constitutions and Commitment: The Evolution of Institutions Governing Public Choice of Seventeenth-Century England, $49 \mathrm{~J}$. ECON. HIST. 803, 808 (1989) (emphasis added); see also Barry R. Weingast \& William J. Marshall, The Industrial Organization of Congress; or Why Legislatures, Like Firms, Are Not Organized as Markets, 96 J. POL. ECON. 132 (1988) (discussing why it can be beneficial for legislatures non-market exchanges can be more beneficial than market exchanges); Paul R. Milgrom, Douglas C. North \& Barry R. Weingast, The Role of Institutions in the Revival of Trade: The Law Merchant, Private Judges, and the Champagne Fairs, 2 ECON. \& POL. 1 (1990) (explaining the importance of a good reputation in trade). 
respective objectives and expectations. Thus, formal contracts can optimize the value of business relationships by reducing overall transaction costs while increasing trust, decreasing ill-will, and actively deterring opportunistic behavior from either party by assigning a guaranteed high cost for engaging in such behavior. Conversely, especially when the different parties' interests are not naturally aligned, poorly drafted contracts can destroy value. ${ }^{253}$

Thus, a company's welfare hinges on how competently and creatively that company's lawyers can work with managers to add value to the firm through the contract language they negotiate and draft. This is where the in-house counsel's knowledge of management and operations, as well as the business of the company, is key. It allows the counsel to intelligently see around corners to anticipate areas of risk and proactively structure strategy or relationships to advance the business objectives. Thus, creativity extends to foreseeing potential exchange hazards (particularly those associated with specialized asset investments, uncertainty, and difficult performance measurements) and preemptively resolving them by either "defin[ing] remedies for foreseeable contingencies or [by] specify[ing] processes for resolving unforeseeable outcomes."254 It is also important to note that outside counsel have in-depth knowledge and skills that in-house counsel does not. Often they are experts in a particular area of law, with a broad knowledge working with many clients in this area of law. They also may become aware of trends that in-house counsel may not see. Thus, it is the appropriate mix of the different expertise and knowledge of in-house and outside counsel that provides the greatest benefits to the organization.

A study by Bozovic and Hadfield found that "companies, large and small, that described innovation-oriented external relationships reported making extensive use of formal contracts to plan and manage these relationships." ${ }^{255}$ For example, the manager of an optics system firm stated:

I don't want to do business without a contract. . . . If you're going to invest in something, even if we are putting our time into it, I have to understand who is going to own what and how it's going

253. See, e.g., Apple Computer, Inc. v. Microsoft Corp., 717 F. Supp. 1428, 1430-32, 1435 (N.D. Cal. 1989) (stating in a lawsuit brought by Apple against Microsoft for violating Apple's copyrights for the Macintosh graphical user interface: "Had it been the parties' intent to limit the [Apple] license to the Windows 1.0 interface, they would have known how to say so.").

254. Laura Poppo \& Todd Zenger, Do Formal Contracts and Relational Governance Function as Substitutes or Complements?, 23 STRAT. MGMT. J. 707, 707 (2002).

255. Bozovic \& Hadfield, supra note 247, at 1. 
to be ... how the future rights are going to be handled.... I mean if you're just selling something, then I guess that means the UCC applies. There's a commercial code and you know, you could imply the terms. But when you're doing innovation and the kind of stuff we do, often there's no pattern for what you're doing before. So you need to have some kind of agreement.. [sic] particularly if there's a lot of money involved. I mean sometimes these ideas like I said the one that was millions of dollars, we have another one that we've generated 3 million dollars of royalties on it, it's all documented, there's 3 [sic] amendments to that agreement. ${ }^{256}$

Bozovic and Hadfield found, however, that managers of 'innovationoriented external relationships" "[d]o not... generate these formal contracts in order to secure the benefits of a credible threat of formal contract enforcement. Instead, like Macaulay's original respondents, they largely relied on relational tools such as termination and reputation to induce compliance. ${ }^{257}$

We agree with Bozovic and Hadfield's assertion that:

[F]ormal contracting-meaning the use of formal documents together with the services of an institution of formal contract reasoning-serves to coordinate beliefs about what constitutes a breach of a highly ambiguous set of obligations. This coordination supports implementation of strategies that induce compliance-despite the presence of substantial ambiguity ex ante at the time of contracting - with what is fundamentally still a relational contract. ${ }^{258}$

This assertion is supported by a study by Poppo and Zenger of outsourcing relationships in information services during the 1990s. ${ }^{259}$ They found that relational governance and formal contracts did complement each other. Their study revealed that using both contracts and trust-building directly and indirectly increased exchange performance as measured by satisfaction with the quality, cost, and responsiveness of the outsourced service: "The presence of clearly articulated contractual terms, remedies, and processes of dispute resolution as well as relational norms of flexibility, solidarity, bilateralism, and continuance may inspire confidence to cooperate in interorganizational exchanges." ${ }^{260}$ Supporting the importance of having counsel that is both competent and creative, Poppo

256. Id. at 45 .

257. Id. at 1-2.

258. $I d$. at 2 .

259. Poppo \& Zenger, supra note 254, at 707-25.

260. Id. at 712 . 
and Zenger further found that increases in the level of relational governance were associated with greater levels of contractual complexity, and vice versa. ${ }^{261}$

Jim Wuthrich, the head of Warner Brothers' home video division, based his firm's path-breaking deal with BitTorrent for the peer-to-peer online distribution of its films and television shows not only on the contract the lawyers negotiated but also on BitTorrent's choice of leading filmindustry lawyer Clive Davis to represent BitTorrent. ${ }^{262}$ Davis helped distinguish BitTorrent from Napster, which had decimated Warner Brothers' record business by making it easy for users to pirate copyrighted music. ${ }^{263}$ Wuthrich also accepted his responsibility, as the manager in charge of the deal, to work with the lawyers to address both the legal risk of licensing Warner Brothers' content and the business risk of not licensing it.

\section{B. Enhancing, Leveraging, and Transforming the Value of Knowledge Assets and Other Firm Resources}

Like the failure to institute proper corporate governance practices, ${ }^{264} \mathrm{a}$ company's failure to implement proper legal tools to protect, leverage, and transform its assets can prevent it from realizing the full value of those assets. The law provides many intellectual property ("IP") rights businesses can utilize to protect and enhance its intellectual capital, including patents, copyrights, trademarks, and trade secrets (e.g., formulas, processes, customer lists, and other information that gives a firm competitive advantage by being kept secret). ${ }^{265}$ Companies can use "patents, copyrights, and trade secrets to command premium prices, to exact royalties, to reduce costs, and to erect barriers to entry," and trademarks to "help create and preserve brand equity.", "66

Unlike many of its competitors who were unwilling to take the litigation risk, EMC Corporation decided to acquire VMware, a pioneer in x86 software virtualization technology, even though VMware was embroiled in a patent infringement lawsuit with Microsoft at the time. ${ }^{267}$

261. Id. at 721 .

262. Constance E. Bagley \& Reed Martin, Warner Bros. and BitTorrent, Harv. Bus. Sch. Case No. 807-012 (2006).

263. Id.

264. Barney \& Hansen, supra note 222.

265. BAGLEY, supra note 71, at 151.

266. Id.

267. Bagley et al., EMC Corp.: Proposed Acquisition of VMware, Harv. Bus. Sch. Case No. 807-153 (2006). 
EMC's CEO Joe Tucci and its GC Paul Dacier convinced that [sic] board of directors that the benefits of the acquisition outweighed the risks. This calculus was based in part on EMC's ability to use its own patents as bargaining chips, its own internal expertise in litigating patent cases, its ability to limit its enterprise risk by doing a reverse triangular merger so VMware would be a separate subsidiary, and its relationship with Microsoft, which was both a competitor and a partner. About a year after the acquisition, Microsoft CEO Steve Ballmer called Tucci proposing that both sides dismiss their claims because 'friends do not sue friends.' A company that EMC acquired in 2004 for roughly $\$ 635$ million had market capitalization of more than $\$ 43$ billion on August 15, 2014. (EMC spun off 20 percent of VMware's shares in an initial public offering in 2007; as of August 15, 2014, EMC's 80 percent stake in VMware was worth roughly $\$ 34$ billion, [nearly 57\%] of EMC's total market capitalization of $\$ 60$ billion.) Had EMC been unable to transform itself from primarily a commodity hardware manufacturer into a data solution provider, it would not be trading at its current multiple of roughly twenty-four times earnings. ${ }^{268}$

There are three qualifying points: First, IP rights are rarely, if ever, sufficient to create sustained competitive advantage on their own. As Margaret Peteraf noted, "If the innovation is no more than a clever and complex assembly of relatively available technologies, then no wall of patents could keep opponents out." ${ }^{269}$ Firms must therefore create an "ongoing stream of innovation in response to both consumer need for cheaper or more differentiated products or for what Apple co-founder Steve Jobs was a genius at anticipating: products customers did not realize they needed until they saw them.,"270

Second, a firm should never use its resources to protect or establish its IP rights at the expense of innovation itself:

Polaroid ultimately won its lawsuit against Kodak for infringement of its patents on instant film and cameras, but did the attendant management distraction... contribut[e] to Polaroid's (and Kodak's) failure to appreciate the threats and opportunities posed by digital photography? [Did] Apple's multi-year litigation against Microsoft and Hewlett-Packard for copyright infringement... distract Apple from continuing to

268. Bagley, supra note 73, at 31-32 (citations omitted).

269. Margaret A. Peteraf, The Cornerstones of Competitive Advantage: A ResourceBased View, 4 Strat. Mgmt. J. 179, 187 (1993).

270. Bagley, supra note 73 , at 35 . 
improve the Macintosh computer[?] $]^{271}$

As Polaroid learned the hard way, winning the court case against a key competitor can be a pyrrhic victory if it distracts a firm from redeploying resources to meet changing needs in the marketplace. ${ }^{272}$

Third, managers and their lawyers must avoid overly protecting a firm's IP rights when the business strategy requires giving users the right to at least some degree of "unauthorized" copying. Gillian Hadfield provides the following example. Consider, she postulated, what approach a lawyer should take to drafting the terms of use for posting CBS Television content online. ${ }^{273}$ "Surely the answer is to put out a set of terms that locks up CBS's ownership over its content?"274 CBS Television's Executive Vice President and General Counsel Jonathan Anschell responds, "Not so."275 Instead, he argues:

We need lawyers who understand that in the world of new media if you lock it down, you don't get the kind of user-generated content that is such an important component of the new media. But when we tell lawyers that, they come back with the polar opposite - a set of terms that is a user's dream but a contentprovider's nightmare. We need something in between these two extremes, but we find it very hard to locate the providers who know how to think about that. ${ }^{276}$

Lawyers need to not only understand the law, but also need to understand in this innovative world, as information becomes digitized, disruption of traditional businesses, information transfer and processes will occur. This can lead to the demonetization of certain services and products. Providing products and services widely and for free may at times have greater value to the company and society than the natural legal instinct to protect and limit access to them.

\section{Creating Options}

Legally astute managers recognize the inherent value of options and will work with strategically astute lawyers to use the law to create them. ${ }^{277}$ An option is the right, but not the obligation, to defer a decision until a

271. Id. at 37-38.

272. Id. at 35 (citations omitted).

273. Hadfield, supra note 213, at 4.

274. Id.

275. Id.

276. Id. (quoting CBS's General Counsel Anschell, explaining that locking it down is not always the best decision).

277. Bagley, supra note 68 , at 378-90. 
future date. ${ }^{278}$ Real options theory assigns inherent value to deferring decisions of uncertainty to a later date. ${ }^{279}$ Such options include an option to purchase real property or stock, the right to terminate a joint venture, subjecting a founder's shares to vesting, ${ }^{280}$ and securing coinvestment rights in future venture capital rounds. ${ }^{281}$

\section{Strategic Compliance Management}

As recent corporate scandals evidence, a company's failure to effectively manage its legal compliance can result in high, negative monetary returns for the firm in the form of criminal and civil penalties. ${ }^{282}$ And these large penalties represent only a portion of the noncomplying firm's total loss, with legal fees often exceeding the monetary penalties imposed. ${ }^{283}$ Fraud alone can cost a typical company between one and six percent of its annual sales revenues. ${ }^{284}$ As a result, the "ability to prevent fraud, or value loss through fraud, has become a potential source of competitive advantage and improved financial performance for firms in today's economy." 285 Conversely, illegal behavior can lead to the demise of a firm, as happened with Drexel Burnham Lambert ${ }^{286}$ and Steve Cohen's hedge fund SAC Capital Advisors in the wake of massive insider trading by their managers. ${ }^{287}$

Creating a law-abiding culture that does not diminish managers' competitive drive is difficult but certainly not impossible. Legally astute

278. RESTATEMENT (SECOND) OF CONTRACTS $§ 25$ (1981).

279. Bruce Kogut \& Nalin Kulatilaka, Capabilities as Real Options, 12 ORG. SCI. 744$758(2001)$.

280. Constance E. Bagley \& Craig E. Dauchy, The Entrepreneur's Guide to BUSINESS LAW 93-94 (4th ed. 2011).

281. Id. at 476 .

282. See supra text accompanying notes 3-40 (discussing the penalties for corporate malfeasance).

283. See, e.g., Brinded, supra notes 6 \& 14 (demonstrating the extremely large penalties and legal costs that companies are often forced to pay).

284. Karen Schnatterly, Increasing Firm Value Through Detection and Prevention of White-Collar Crime, 24 StRat. Mgmt. J. 587, 587 (2003).

285. Id.

286. See, e.g., STEWART, supra note 44 (describing Drexel Burnham Lambert's collapse after unethical and illegal activities eventually led to bankruptcy).

287. Peter Lattman \& Ben Protess, $\$ 1.2$ Billion Fine for Hedge Fund SAC Capital in Insider Case, N.Y. TIMES (Nov. 4, 2013, 11:06 AM), http://dealbook.nytimes.com/2013/11/04/sac-capital-agrees-to-plead-guilty-to-insidertrading/ [perma.cc/NUT7-YGFY]. Cohen was permitted to transfer his personal and family assets to a successor firm Point72 Asset Management, but Point72 Asset Management cannot manage outsider money and SAC Capital was forced to liquidate. 
TMTs practice "strategic compliance management."288 There are ten steps:

1. Start with ethics and start at the top

2. Help shape the rules of the game

3. Look for opportunities to convert constraints into opportunities

4. Understand duties and anticipate risks

5. Benchmark both accidents and violations and near-misses

6. Avoid conflicts of interest and fully disclose

7. Implement appropriate controls and processes

8. Compete hard but fairly

9. Educate all employees and distribute written policies

10. Be prepared to deal with compliance failures. ${ }^{289}$

The application of these ten steps is context-dependent, and each firm should tailor its controls, policies, processes, and practices to the noncompliance risks that are most pertinent to that firm. ${ }^{290}$ Because compliance is not a case of one size fits all, replication of best practice may be illusive. ${ }^{291}$ Still, independent directors should in every context "make it clear to the general counsel (and to the CEO and other senior management) that [they expect regular reports covering] ... actual or potential material violations of law, breaches of fiduciary duty, and other 'substantial legal concerns." ",292

Whistleblowers can be the canaries in the mine shaft, providing early warning of imminent disaster. ${ }^{293}$ Too often they are ignored, isolated, and shunned. ${ }^{294}$ Managers need to protect whistleblowers from retaliation by

288. B AGLEY, supra note 71 , at 50,85-86.

289. See id. at 47-50 (setting forth a nine-step program).

290. See id. at 49-56 (providing a basis for management to create a compliance platform and noting how "[s]uch a capability is path dependent ... and is not a resource that can be readily bought and sold").

291. Teece et al., supra note 189, at 517.

292. William W. Horton, Serving Two (or More) Masters: Professional Responsibility Challenges for Today's In-House Healthcare Counsel, 3 J. HeALTH \& LIFE SCI. L. 187, 194 (2010); see also American Bar Association Task Force on Corporate Responsibility, Report of the American Bar Association Task Force on Corporate Responsibility, 59 Bus. LAw. 145, 161 (2003) (suggesting that directors work actively with general counsel on "oversight responsibilities" and "legal compliance matters").

293. Constance E. Bagley, Managers and the Legal Environment: Strategies FOR THE 21ST CENTURY 37 (8th ed. 2016) ("Like the birds taken into mines to detect deadly gases, they often perceive dangers before top management.").

294. Joel Chineson, Bureaucrats with Conscience, LEgAL Times, Apr. 17, 1989, at 50 (quoting a whistleblower who had warned of violations at a nuclear power plant: "Be prepared for old friends to suddenly become distant. Be prepared to change your type of job and lifestyle. Be prepared to wait years for blind justice to prevail."); see, e.g., Mike Spector, Takata U.S. Employees Saw Problems in Air-Bag Tests, WALl. ST. J. (Nov. 24, 2015, 7:24 PM ET), http://www.wsj.com/article_email/takatas-u-s-employees-flagged- 
not only superiors ${ }^{295}$ but also coworkers and provide both moral and psychological support. ${ }^{296}$ At MassMutual Financial the compliance organization uses policies, posters, emails, blogs and other means of communication to ensure its employees understand not only the importance, but the obligation, to speak up if they see an issue they believe may be unethical or a violation of regulation or law.

In addition, incentives matter:

If an employee is held accountable for traditional corporate tasks whose performance will determine his success or failure, and is also urged to undertake social objectives on which his performance is not measured, the result is inevitable. Even the most well-intentioned employee will devote his time and attention to the functions on which his career progress depends. ${ }^{297}$

As Judge Doumar commented after a jury found Kidde liable for misappropriating trade secrets belonging to X-It, a start-up that had developed an innovative fire escape ladder:

This case is the very epitome of corporate governance in the last decade of the twentieth century - where greed and the resultant pressure on corporate officers to produce results out of line with the actual value of the assets they manage turns those officers into vultures, devouring the very businesses which they are trying to enhance. ${ }^{298}$

Legally astute TMTs practice strategic compliance management with the goal of adding, and not simply preventing the destruction of, firm value. Thus, the construct extends beyond simple legal compliance and encompasses the competitive advantage attainable when a firm goes beyond what the law requires. For example, at a time when the Food and

reporting-issues-over-air-bags-1448411043-1MyQjAxMTE1MjIzNjgyMTYxWj

[perma.cc/9AAQ-293J] ("For a decade, Takata Corp. employees in the U.S. raised concerns internally about misleading testing reports on air bags that later became prone to explosions.").

295. The Department of Veterans Affairs allegedly "silence[s] and punish[es] whistleblowers." In one case, after a food services manager at the Philadelphia site reported faulty sanitation practices, his supervisors tried to fire him for eating "four old sandwiches" that cost about \$5; he was also reassigned to clean a morgue. Emily Wax-Thibodeaux, He Blew the Whistle on the VA - and Then Was Almost Sacked for Eating Stale Sandwiches WASH. Post. Blog (Sept. 21, 2015), https://www.washingtonpost.com/news/federaleye/wp/2015/09/21/he-blew-the-whistle-on-the-va-and-then-was-almost-sacked-for-eatingstale-sandwiches/ [perma.cc/29M3-VHLK].

296. BAGLEY, supra note 293.

297. DROTNING, supra note 195 , at 259.

298. X-It Products, L.L.C. v. Walter Kidde Portable Equipment, Inc., 227 F. Supp. 2d 494, 546 (E.D. Va. 2002). 
Drug Administration was considering requiring firms to label their products to show the amount of hydrogenated oils (trans fats) they contained, PepsiCo's Frito Lay division stopped using hydrogenated oils in its potato chips and other snacks, then obtained Food and Drug Administration approval to label its products prominently as having zero trans-fats. ${ }^{299}$ MassMutual Financial symmetrically used its knowledge of information obtained in nationally available Death Master Files to both stop paying annuities and to pay life insurance benefits, even though the life insurance contracts require the beneficiary to provide proof of death before payment is due. ${ }^{300}$

\section{E. Shaping the Regulatory Environment}

Firms do not act in isolation from the societal context in which they operate, ${ }^{301}$ and they can help shape the rules that govern their conduct. ${ }^{302}$

299. BAGLEY, supra note 71 , at 77.

300. See March 18, 2014 email submitted by Todd G. Picken, Corporate Vice President and Treasurer of MassMutual Financial Group, included on pages 183-184 of the Comments Submitted in Response to 79 FR 11735 - Certification Program for Access to the Death Master File, Federal Register Volume 79, Issue 41 (Mar. 3, 2014), available through the U.S. Department of Commerce National Technical Information Service website. The email states that MassMutual has used the Social Security Death Master File to "(1) determine if periodic benefit payments were being paid to deceased contract owners or beneficiaries; (2) identify in force life insurance policies with deceased insureds; and (3) as appropriate, to reach out to those connected with the policies to begin the claims adjudication process."

301. See generally BAGLEY, supra note 71 (demonstrating the way businesses can use law and learn from past corporate scandals to succeed); BAGLEY, supra note 293, at 3 (stating that firms operate "within a broader social context").

302. See Bruce M. Owens \& Ronald Braeutigan, The Regulation Game: Strategic USE OF THE ADMINISTRATIVE PROCESS 9 (1978) (discussing how regulatory agencies can be strategically influenced by the firms they regulate); MiKE H. RYAN ET AL., CORPORATE Strategy, Public Policy and the Fortune 500: How America's Major Corporations INFLUENCE GOVERNMENT (1987) (discussing corporations' increasing effect on public policy decisions); Frank ShipPer \& Marianne M. Jennings, Business Strategy for the Political ARENA xviii (1984) (discussing the relationships between PACs, businesses, and their influence in Washington); Vinod Aggarwal, Corporate Market and Nonmarket Strategies in Asia: A Conceptual Framework, 3 Bus. \& PoL. 89 (2001) (evaluating "firm strategies in Asia... which concern efforts to respond to and influence the politicaleconomic-social environment"); Bagley, supra note 190, at 3 (recognizing how "managerial actions will affect the law and how it is interpreted and applied over time"); David P. Baron, Integrated Strategy: Market and Nonmarket Components, 37 CAL. MgMT. Rev. 47, 48 (Winter 1995) (defining one objective of a firm's nonmarket strategy as shaping the firm's "market environment" by lobbying for certain legislation); Gerald D. Keim \& Carl P. Zeithaml, Corporate Political Strategy and Legislative Decision Making: A Revised Contingency Approach, 11 ACAD. MGMT. REV. 828, 828 (1986) (analyzing the "corporate political efforts to influence...[legislative] decisions"); Douglas Schuler, Corporate Political Strategy and Foreign Competition: The Case of the Steel Industry, 39 ACAD. 
Preston and Post submit, "there is an inherently interactive and symbiotic relationship between the private business organization and the larger society that constitutes its host environment." 303 Hence, "the task of anticipating, understanding, evaluating, and responding to public policy developments within the host environment is itself a critical managerial task" wherein firms can realize value. ${ }^{304}$ Even jurists recognize this symbiosis: in his dissenting opinion in Citizens United v. Federal Election Commission, ${ }^{305}$ U.S. Supreme Court Justice John Paul Stevens noted that "[b]usiness corporations must engage the political process in instrumental terms if they are to maximize shareholder value." 306

Reflecting this relationship, the lead author developed an integrative framework for understanding the interrelationship of a firm's resources, competitive environment, value proposition, activities in the value chain, public law, and the broader societal context. ${ }^{307}$ The unit of analysis is the $\mathrm{TMT}^{308}$ which "evaluates and pursues opportunities for value creation and capture while managing the attendant risks." ${ }^{309}$ This is depicted in Figure $3 .{ }^{310}$

MGMT. J. 720 (1996) ("examin[ing] the political strategies of U.S. firms aimed at protecting the domestic market from foreign competition"; Brian Shaffer, Firm-Level Responses to Government Regulation: Theoretical Approaches, 21 J. MGMT. 495, 495 (1995) (discussing how firms "advance their political interests through environmental scanning, lobbying, political action committees (PACs), collation building ... among others"); David B. Yoffie, Corporate Strategy for Political Action: A Rational Model, in BUSINESS STRATEGY AND Public Policy: Perspectives From Industry AND ACAdemia 92-111 (Alfred A. Marcus et al. eds., 1987) (discussing lobbying and working with regulatory bodies); David B. Yoffie \& Sigrid Bergenstein, Creating Political Advantage: The Rise of The Corporate Political Entrepreneur, 28 CAL. MGMT. REV. 124, 126 (1985) (suggesting that the goal of political business strategy is to "secure access to key decision makers, influence policy, and enhance the profitability of business operations").

303. Lee E. Preston \& James E. Post, Private Management and Public Policy: The PrinciPle of PUblic ReSPONSIBILITy 12 (1975).

304. Id. at 4.

305. 558 U.S. 310 (2010).

306. Id. at 454. As with other managerial functions, the board of directors has an obligation to oversee compliance with applicable electioneering laws and to ensure that a firm's political activities, including corporate political contributions, are in accord with the firm's strategy and values. Constance E. Bagley, et al., A Board Member's Guide to Corporate Political Spending, HARv. Bus. Rev. (Oct. 30, 2015), https://hbr.org/2015/10/aboard-members-guide-to-corporate-political-spending [perma.cc/2CK6-MUGS].

307. BAGLEY, supra note 293 , at 3 .

308. B AGLEY, supra note 71, at 224-28.

309. BAGLEY, supra note 293 , at 3.

310. Id. 
FIGURE 3: SySTEMS APPROACH TO LAW, BUSINESS, AND STRATEGY

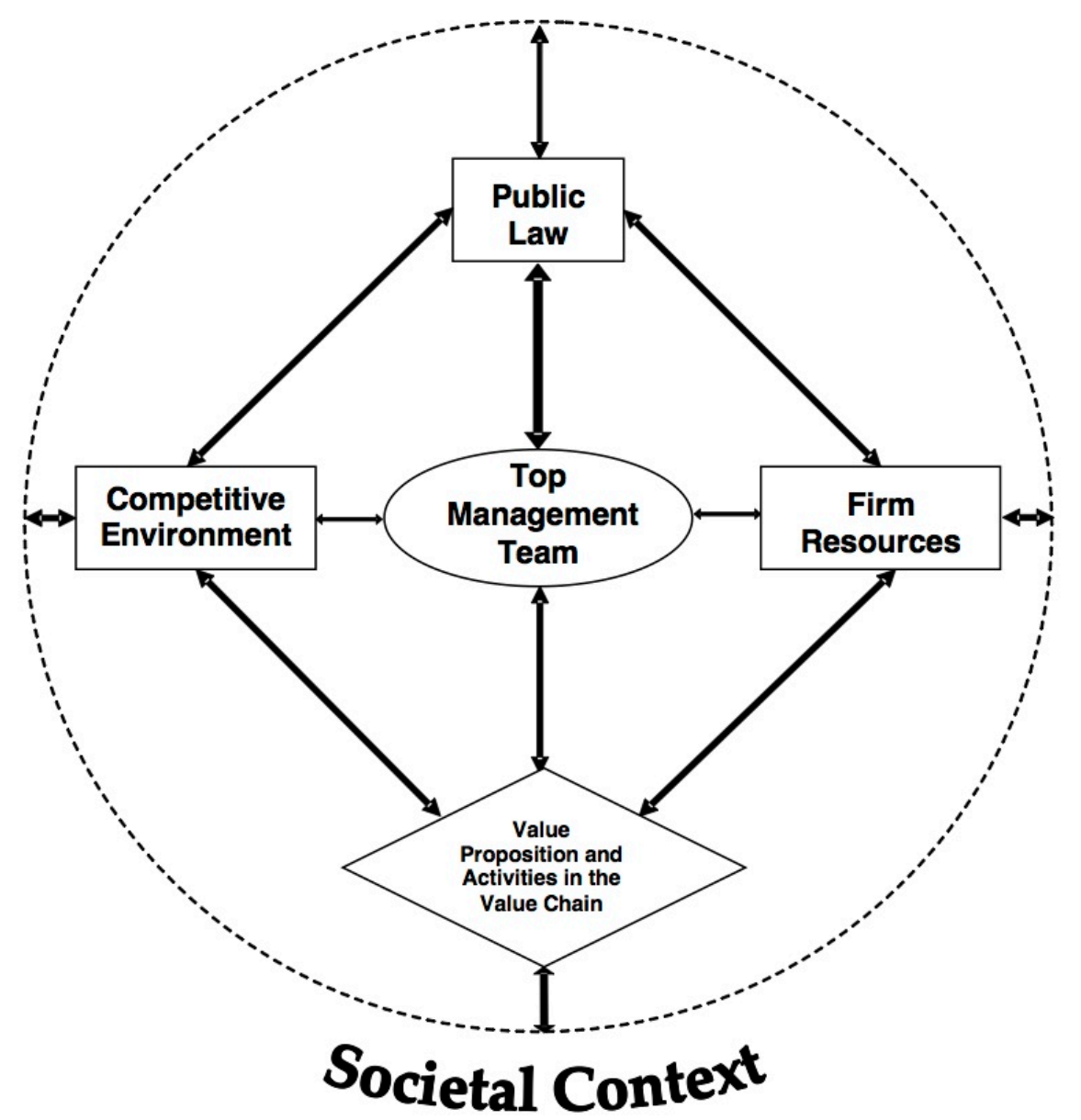


By, for example, engaging the political process, companies can create firm value by helping to shape the "rules of the game." ${ }^{311}$ To do so, Yoffie and Bergenstein called on firms to develop an entrepreneurial strategy for creating and sustaining political advantage. ${ }^{312}$ Efforts to change the rules of the game need to be integrated into a firm's overall business strategy. ${ }^{313}$

The success of FedEx's hub-and-spoke distribution system was predicated, in part, on its ability to shape the regulations governing commercial aircrafts. Frederick W. Smith, founder of Federal Express, characterized this as

a very big part of the FedEx story which has hardly ever been commented upon: The parallel effect of the relaxation of government regulation which allowed FedEx to begin operations to begin with, in what was really a loophole. And then it was codified when airlines were deregulated in '77-'78. And then in 1980, the federal government deregulated interstate transportation. So it was deregulation, much of which we induced. ${ }^{314}$

The ultimate success of Uber, the car-sharing service, will depend in substantial part on its ability to persuade livery regulators to regulate its activities with a light touch. Uber promoted enactment of a California law governing its activities. Although Uber was subsequently charged with violating it, the law helped legitimize its activities. ${ }^{315}$ Uber also

311. Douglass C. North, Institutions, Institutional Change and Economic PERFORMANCE 3 (1990); see generally BAGLEY, supra note 71 (discussing using the political process to create value).

312. Yoffie \& Bergenstein, supra note 302, at 126, 136 (for example, MCI's business and political strategies, which were designed to break AT\&T's monopolization of the telecommunications industry, were "inextricably linked" and essential to MCI's success).

313. Baron, supra note 302.

314. Online Extra: Fred Smith on the Birth of FedEx, BloOMBERG Bus. (Sept. 19, 2004), http://www.bloomberg.com/bw/stories/2004-09-19/online-extra-fred-smith-on-the-birth-offedex [perma.cc/7ERG-RTF7].

315. The California Public Utilities Commission enacted rules in 2013 to regulate Transportation Network Companies (TNCs), which "provide prearranged transportation services for compensation using an online-enabled application or platform (such as smart phone apps) to connect drivers using their personal vehicles with passengers." Transportation Network Companies, CAL. PubliC UTIL. COMM'N, http://www.cpuc.ca.gov/PUC/Enforcement/TNC/ [perma.cc/UU2H-YA7N] (last modified May 11, 2015). In July 2015, an administrative law judge ruled that Uber should be fined more than \$7 million for violating a state law requiring it to report details of its rides, including the number of requests it received for individuals using wheelchairs or accompanied by a service animal. Laura J. Nelson et al., Uber Should Be Suspended in California and Fined \$7.3 Million, Judge Says, L.A. TIMES (July 15, 2015, 5:59 PM), http://www.latimes.com/business/la-fi-uber-suspended-20150715-story.html [perma.cc/34HJ-8RBW]. 
successfully reached an agreement in mid-2015 with the mayor of New York City and the City Council to "collaborate" on a joint transportation study to determine Uber's effect on traffic and the environment. ${ }^{316}$ As a result of the agreement, a proposed City Council bill, termed "onerous" by some, that would have required Uber to stay within the city limits and would have imposed a cap on the number of Uber drivers, has been abandoned, at least for the time being. ${ }^{317}$ Uber's "no-holds-barred expansion strategy" has been less successful in parts of Europe and Asia. Uber shut down its service in Frankfurt, Germany, after operating there for less than two years, ${ }^{318}$ and it recently withdrew from Hamburg and Düsseldorf as well. ${ }^{319}$ Uber reportedly "miscalculated how best to gain the support of skeptical locals unaccustomed to its win-at-all-costs tactics" and "underestimated the regulatory hurdles of doing business in Europe's largest economy." 320 Regulators in London are also "mulling changes" that could severely restrict Uber's expansion. ${ }^{321}$ Uber "faces regulatory hurdles" in India as well, in addition to domestic competition. ${ }^{322}$ For example, India allows only "for-hire vehicles," and not individuals with private cars, to offer rides using a smartphone application. ${ }^{323}$ In October 2015, the central Indian government issued non-binding guidelines that require ride-hailing companies to obtain state permits to operate in a specific location and give the states the right to set maximum fare amounts. ${ }^{324}$ If implemented, these new rules may actually help Uber expand into New Delhi, which had banned its services. ${ }^{325}$

The short-term housing rental service Airbnb spent more than $\$ 8$

316. Ray Hennessey, New York City Caves on Plan to Cap Uber Drivers, ENTREPRENEUR (July 22, 2015), http://www.entrepreneur.com/article/248729 [perma.cc/MP37-7KE3].

317. Id.

318. Mark Scott, Uber's No-Holds-Barred Expansion Strategy Fizzles in Germany, N.Y. TiMES (Jan. 3, 2016), http://www.nytimes.com/2016/01/04/technology/ubers-no-holdsbarred-expansion-strategy-fizzles-in-germany.html [perma.cc/DL6U-3S2E].

319. Id.

320. Id.

321. Id.

322. Anindya Upadhyay, Uber Drivers in India Outearn Some Bankers. But for How Long?, BlOOMBerg Bus. (Oct. 19, 2015, 11:31 AM PDT), http://www.bloomberg.com/news/articles/2015-10-19/uber-drivers-banker-beating-pay-inindia-cools-as-cabs-multiply [perma.cc/GVZ9-A294].

323. Id.

324. Siddharth Vikram Philip, India Said to Issue Guidelines for Uber, Other RideHailing Apps, BloOmberg Bus. (Oct. 13, 2015, 5:47 AM PDT), http://www.bloomberg.com/news/articles/2015-10-13/india-said-to-issue-guidelines-foruber-other-ride-hailing-apps-ifpd5y84 [perma.cc/X2MN-YQ36].

325. Id. 
million to defeat San Francisco Proposition F in November 2015. ${ }^{326}$ If enacted, the Proposition would have limited users of Airbnb (and other short-term housing rental sites) to a maximum of seventy-five days of rentals per year, down from the existing ninety-day limit. ${ }^{327}$ Approximately one week after the voters rejected Proposition F, Airbnb softened its tone with regulators in San Francisco and elsewhere, ${ }^{328}$ "pledging a renewed spirit of cooperation" and issuing the Airbnb Community Compact. ${ }^{329}$ The Compact provides that the company will, for example, provide city officials certain anonymous information about the hosts and guests using its services, work to prevent illegal hotel landlords from operating on its site, and pay its " fair share" "of applicable hotel and tourist taxes. ${ }^{330}$

In addition to working with regulators and engaging in political activities, firms can use litigation to help level the competitive playing field. Telecommunications firm U S West, a regulated telephone service provider, sued to invalidate the regulations banning regulated providers from selling cable television services to their subscriber base. U S West successfully sued to invalidate those restrictions on the grounds that they violated the firm's free speech rights under the U.S. Constitution. ${ }^{331}$

Data miners for brand name drug manufacturers also used the First Amendment to invalidate a Vermont statute that required physicians to opt in before their physician-identifying prescribing information could be sold to pharmaceutical companies. ${ }^{332}$ A drug company sales representative, ${ }^{333}$ as well as Amarin Pharma, a brand name pharmaceutical manufacturer, and four doctors, ${ }^{334}$ successfully challenged the Food and Drug Administration's ban on promoting off-label uses of pharmaceuticals as unconstitutional restraints on their rights of free speech, in cases that could have far-reaching implications for government regulation of commercial speech. ${ }^{335}$

326. Elizabeth Weise, San Francisco Rejects Anti-Airbnb Measure, USA TOdAY (Nov. 4, 2015, 1:06 p.m. EST), http://www.usatoday.com/story/tech/2015/11/04/anti-airbnbmeasure-fails-san-francisco/75138092/ [perma.cc/W865-L8PR].

327. Id.

328. Mike Isaac, Airbnb Pledges to Work with Cities and Pay 'Fair Share' of Taxes, N.Y. TIMES (Nov. 11, 2015), http://www.nytimes.com/2015/11/12/technology/airbnbpledges-to-work-with-cities-and-pay-fair-share-of-taxes.html [perma.cc/Q5PV-FNXZ].

329. Id.

330. $I d$.

331. Bagley \& Roellig, supra note 73 (citations omitted).

332. Sorrell v. IMS Health Inc., 131 S. Ct. 2653 (2011).

333. United States v. Caronia, 703 F.3d 149 (2d Cir. 2012).

334. Peter J. Henning, FDA's “Off-Label” Drug Policy Leads to Free-Speech Fight, N.Y. Times, (Aug. 10, 2015), http://www.nytimes.com/2015/08/11/business/dealbook/fdasoff-label-drug-policy-leads-to-free-speech-fight.html [perma.cc/KM63-E7QR].

335. See Constance E. Bagley et al., Snake Oil Salesmen or Purveyors of Knowledge: 


\section{TRAINING THE NEXT GENERATION OF LEGALLY ASTUTE MANAGERS AND STRATEGICALLY ASTUTE LAWYERS}

As the Academy of Legal Studies in Business (“ALSB") has stated: "Law and ethical behavior are foundational to civilized society. Legal studies, an inclusive term that encompasses the diverse ways that law and ethics shape the global environment of business, is an integral part of business education and informs effective and responsible business decisions and managerial behavior." ${ }^{\text {"36 }}$ When Robert Aaron Gordon and James Edwin Howell published the influential report Higher Education for Business $^{337}$ in 1959, most top business schools had at least one required course in business law. ${ }^{338}$ By 2008 , only four of the top twenty graduate schools (as reported by Business Week or U.S. News \& World Report) required a course in business law or the legal environment of businessCarnegie Mellon, Michigan, the University of Pennsylvania's Wharton School, and Yale. ${ }^{339}$ A review of the MBA curriculum at the top twenty business schools, as ranked by U.S. News \& World Report in $2015,{ }^{340}$ did not reveal any core or required courses specifically dedicated to business law or the legal environment of business. Three schools-the Stanford Graduate School of Business, Harvard Business School, and New York University's Stern School of Business-required courses that included consideration of legal issues, as described in their web-site course descriptions. ${ }^{341}$ The Wharton School offers "Legal Studies and Business

Off-Label Promotions and the Commercial Speech Doctrine, 23 CORNELL J.L. \& PUB. POL'y 337 (2013) (analyzing the judicial and regulatory effects on the commercial speech doctrine).

336. Academy of Legal Studies in Business, ALSB Strategic Plan: Core Values (May 22, 2012), http://alsb.mobi/infobox/strategic-plan [perma.cc/54PG-6UEY].

337. Robert Aaron Gordon \& James Edwin Howell, Higher Education for BUSINESS (1959).

338. Id. at 204.

339. Constance E. Bagley et al., Deep Links: Does Knowledge of the Law Change Managers' Perceptions of the Role of Law and Ethics in Business?, 47 Hous. L. REv. 259, 265 (2010).

340. Best Business Schools Ranked in 2015, U.S. News \& WORLD REPORT, http://gradschools.usnews.rankingsandreviews.com/best-graduate-schools/top-business-schools/mbarankings?int=9dc208 [perma.cc/3B4Q-2VQP] (last visited Dec. 29, 2015).

341. Stanford University requires "Strategy Beyond Markets," which examines the "legal, political, and social environments of business" in the decision-making arena. Personalized Curriculum, STANFORD GSB, https://www.gsb.stanford .edu/programs/mba/academic-experience/curriculum/first-yearcurriculum [perma.cc/ER3X-G8TT] (last visited Jan. 31, 2016). Harvard University requires "Leadership and Corporate Accountability," in which the "legal, ethical and economic responsibilities of corporate leaders" are examined. Required Curriculum, HARVARD BUSINESS SCHOOL, http://www.hbs.edu/mba/academic- 
Ethics" as part of its MBA flexible core curriculum. ${ }^{342}$

The increased emphasis on quantitative research in the wake of Higher Education for Business ${ }^{343}$ has tended to marginalize legal scholarship not based on law and economics or otherwise subject to regression analysis. ${ }^{344}$ Yet, "the things routinely ignored by academics on the grounds that they cannot be measured-most human factors and all matters relating to judgment, ethics, and morality - are exactly what make the difference between good business decisions and bad ones.."345 It is

experience/curriculum/Pages/required-curriculum.aspx [perma.cc/QT4Z-2HRC] (last visited Jan. 31, 2016). The Executive MBA program at New York University's Stern School of Business requires "Professional Responsibility," in which "the importance of understanding the interdependence of markets, ethics and law in a democratic, free market society" are examined. Executive MBA Program, NYU STERN SCHOOL OF BUSINESS, https://www.stern.nyu.edu/programs-admissions/executive-mba/academics/course-

information [perma.cc/K3Z4-X5UR] (last visited Jan. 31, 2016).

342. Core Curriculum Structure, University of PenNSYlvania Wharton MBA, http://mba.wharton.upenn.edu/academics/curriculum/core/ (last visited Dec. 29, 2015).

343. GORDON \& HOWELL, supra note 337, at 107.

344. Nohria \& KhURANA, supra note 113; Richard T. Watson \& Stefan Seidel, A Crisis of Purpose, BizED (Dec. 16, 2015), http://www.bizedmagazine.com/your-turn/a-crisis-ofpurpose?utm_source=HighRoads\%20Solutions\&amp;utm_medium=Email\&amp;utm_camp aign=HighRoads\%20All\%20Emails [perma.cc/HP4Z-AK7S] ("Business schools are in a teleological crisis because they have become homes for theory infrequently sullied by practice, not agents for addressing business problems."). Watson and Seidel note that the publication of Higher Education for Business motivated business academics to apply scientific principles to business research more aggressively, leading to a teleological shift. $I d$. This prompted business schools to focus on "analysis over problem solving." Id. Certain scholars have posited that "practice influenced business research, not vice versa"; others asserted that it was the practitioners, and not the pure scholars, who wrote the "most influential business books." Id. (citing Jeffrey Pfeffer \& Christina T. Fong, The End of Business Schools: Less Success than Meets the Eye, 1 ACAD. MgMT. LEARNing \& Educ. 78 (2002); Stephen Barley, Gordon Meyer \& Debra Gash, Cultures of Culture: Academics, Practitioners and the Pragmatics of Normative Control, 33 ADMIN. SCI. Q. 24 (1980)); see also Stewart Clegg, Managerialism: Born in the USA, 39 ACAD. MgmT. Rev. 566, 572 (2014) (describing the "'physic' envy' that had captured the business school professoriate in the wake of the reforms prompted by the Ford Foundation and the Carnegie Commission") (citation omitted); Gianmarco Massameno, Practitioner Academics and Traditional Academics: A Comparison of Institutional Experiences at the Harvard Business School 1-20 (2014) (unpublished master's independent study, Harvard University) (on file with the third author) (study finding that at the Harvard Business School ("HBS"), on average, "practitioner academics reported a higher level of perceived respect that was statistically significant from students, fellow practitioner academics, and MBAs - not from traditional academics, PhDs, or the administration." Faculty respondents commented that "respect for practitioner academics fluctuated according to what HBS believes the cohort's role should be, or whether they should have a role at all. Other commenters associated increased respect with increased research quality - a task more closely associated with traditional academics than with practitioner academics." (emphasis added)).

345. Warren G. Bennis \& James O'Toole, How Business Schools Lost Their Way, HARv. Bus. REv (May 2005), https://hbr.org/2005/05/how-business-schools-lost-their-way 
therefore not surprising that "[i]n surveys that the Aspen Institute regularly conducts, M.B.A. candidates say they actually become less confident during their time in business school that they will be able to resolve ethical quandaries in the workplace." 346 Jeffrey C. Garten, former Dean of the Yale School of Management, called "enhancing [business leaders'] ethical education at a formative stage... arguably the highest priority that business schools should have." "347 He continued: "All students, for example, should gain a fundamental understanding of business law." "348

In 2012, the ALSB established a presidential task force on the State of the Discipline, ${ }^{349}$ which was chaired by the lead author and later co-chaired by Lucien Dhooge of the Scheller College of Business at Georgia Tech. ${ }^{350}$ The task force worked with the drafters of the revised AACSB standards to ensure that proper attention was paid to legal and regulatory issues. ${ }^{351}$ The new AACSB International accreditation standards, adopted in April 2013 and updated as of January 31, 2015, require coverage of the "[e]conomic, political, regulatory, legal, technological, and social contexts of organizations in a global society." 352

Notwithstanding the clear articulation of the standard, there is anecdotal evidence that certain accreditation reviews occurring after the new standards went into effect may not be devoting sufficient attention to the requirement for adequate coverage of legal and regulatory matters. The AACSB recently reaccredited graduate business programs at schools ranging from the University of California at Los Angeles to Quinnipiac University in Connecticut even though neither program has a required

[perma.cc/CMM3-2MUY].

346. Kelly Holland, Is It Time to Retrain B-Schools? N.Y. TIMES, (Mar. 14, 2009), http://www.nytimes.com/2009/03/15/business/15school.html?_r=1 [perma.cc/A63MGRV8]; see also Watson \& Seidel, supra note 344 (discussing the drift from problem solving to analysis in business school education).

347. Jeffrey C. Garten, B-Schools: Only a C+ in Ethics, BloOMBERG Businessweek (Sept. 4, 2005), http://www.bloomberg.com/bw/stories/2005-09-04/b-schools-only-a-c-plusin-ethics [perma.cc/RUX9-L6VE] (arguing that business schools can "teach students how to apply value judgments when issues are not black and white.").

348. Id.

349. Henry Lowenstein, Building the Manager's Tool Box: Reflections of a Former Business Dean on the State of Law in the Business Curriculum, 30 J. Legal Stud. Educ. 347 (2013). Its members included then ALSB-AACSB liaison Peter Shedd of the University of Georgia and current ALSB-AACSB liaison Janine Hiller of Virginia Tech. Correspondence with the lead author on file with the lead author.

350. Correspondence with the lead author on file with the lead author.

351. Lowenstein, supra note 349.

352. AACSB InTERNATIONAL, ELIGIBILITY PROCEDURES AND ACCREDITATION STANDARDS FOR BUSINESS ACCREDITATION 32 (2015), http://www.aacsb.edu// /media/ AACSB/Docs/Accreditation/Standards/2013-bus-standards-update-jan2015.ashx [perma.cc/ YA5V-UP2C]. 
course in business law or the legal environment of business. ${ }^{353}$ As with interlocking directorships whereby the CEO of one firm heads the compensation committee of the other, and vice versa, having a dean of one school head the accreditation review committee of another school, and vice versa, can color the objectivity of the individuals involved regarding the relative importance of various topics, including legal studies in business. As a result, we call on the AACSB to ensure that review committees pay particular attention to requirements relating to teaching legal and regulatory matters and that they do not permit a sitting dean ("Dean A") of one school ("School A") to serve on the review committee for another school ("School B") if the sitting dean of School B serves on the review committee for School A while Dean A is still the dean of School A and vice versa.

One area of special importance for aspiring business leaders is the law of fiduciary duty, both as it relates to corporate opportunities ${ }^{354}$ and to the broad duties officers and directors owe to shareholders, creditors, and other constituencies, especially when a firm faces a possible change of control ${ }^{355}$ or enters the zone of insolvency. ${ }^{356}$ Of particular concern is the "principle" of shareholder primacy taught in many U.S. finance and economic courses. Such courses often overstate the duty of directors to maximize shareholder value $^{357}$ and understate the economic consequences of failing to act in the best interest of the enterprise and manage for the long term. ${ }^{358}$ The law governing the fiduciary duties of directors has evolved over time and

353. As to University of California at Los Angeles, interview with Constance E. Bagley, Lead Author, Yale Law School, in New Haven, Connecticut, on February 23, 2015. As to Quinnipiac, telephone interview with Constance E. Bagley, Lead Author, in Woodbridge, Connecticut, on June 8, 2015.

354. See BAGLEY, supra note 293, at 620-21.

355. Id. at 621-32.

356. Id. at 741 .

357. See Clegg, supra note 344 , at 568 (the managerialism taught in U.S. business schools lead to the precept that shareholder value was "preeminent"); see also STOUT, supra note 69 (debunking the "myth" of shareholder primacy); Bagley, supra note 69 (discussing constituency statutes that "expressly authorize the board to take into account the interests of all constituencies" and the common law discretion of boards to look beyond the short-term interests of shareholders in most situations); Bagley \& Page, supra note 69, at 898, 921-27 (explaining that directors must act in the best interests of the corporation and may, absent a change in control transaction or the inevitable break-up of the corporation, consider nonshareholder constituencies as long as (1) the directors are not improperly entrenching themselves in office or disenfranchising shareholders and (2) any action taken to thwart a corporate takeover is a reasonable response to the threat posed to the corporation).

358. See generally STOUT, supra note 69 (discussing the thinking that causes corporate managers to focus on short-term earnings at the expense of long-term performance); Clegg, supra note 344, at 570 ("Wall Street greed and political rhetoric were aided and abetted by business education."). 
requires more than the assignment of cases like Dodge v. Ford Motor Co. ${ }^{359}$ to educate future business leaders about what the law does and does not require in this regard. For example, cases like Paramount Communications Inc. $v$. Time Inc. ${ }^{360}$ make it clear that, except when a change in corporate control or break-up of the corporation has become inevitable, ${ }^{361}$ shareholder primacy is a managerial choice not a legal mandate. ${ }^{362}$ The Delaware Supreme Court held that Time directors could legally thwart a fully financed, any-or-all cash offer by Paramount supported by the vast majority of the Time shareholders to protect Time's "journalistic integrity" and the "Time culture." Knowing that the Time shareholders would vote down a proposed stock-for-stock merger with Warner Brothers that was valued by the market as worth less than the Paramount offer, the Time directors restructured the deal as a leveraged buyout of Warner Brothers, which burdened Time with $\$ 10$ billion in new debt, to obviate the need for a Time shareholder vote. Efforts by major Time shareholders, like CalPERS, to require the Time board to let the shareholders choose which deal they favored, failed. As Delaware Chancellor William Allen stated: "The corporation law does not operate on the theory that directors, in exercising their powers to manage the firm, are obligated to follow the wishes of a majority of shares." 363

Henry Mintzberg, Robert Simons, and Kunal Basu called the assertion that companies exist solely to maximize shareholder value a "half-truth[]" that contributed to the "syndrome of selfishness" among firms and executives in the late twentieth and early twenty-first centuries. ${ }^{364}$ They further argued that focusing on shareholder value without taking into account the interests of other stakeholders "reflects a fallacious separation of the economic and social consequences of decisionmaking." " Even shareholder-primacy proponent Michael Jensen acknowledged in the wake of Enron and WorldCom that managers who neglect any corporate

359. 170 N.W. 668 (Mich. 1919).

360. Paramount Commc'ns, Inc. v. Time Inc., 571 A.2d 1140 (Del. 1990).

361. This is often referred to as being in the "Revlon-mode," after the eponymous case Revlon, Inc. v. MacAndrews \& Forbes Holdings, Inc., 506 A.2d 173 (Del. 1986).

362. Bagley, supra note 69. The directors of firms organized as B corporations are not required to maximize shareholder value even when a change in control or break-up has become inevitable. BAGLEY, supra note 293, at 583.

363. Paramount Commc'ns, Inc. v. Time Inc., 1989 WL 79880 (Del. Ch. July 14, 1989), aff'd, 571 A. 2d 1140 (Del. 1990). Similarly, the Court of Chancery subsequently stated, "[d]irectors are not thermometers, existing to register the ever-changing sentiments of stockholders." In re Lear Corp. S'holder Litig., 967 A.2d 640 (Del. Ch. 2008).

364. Henry Mintzberg, Robert Simons \& Kunal Basu, Beyond Selfishness, 44 MIT SloAn Mgmt. Rev., 66, 67-69 (2002).

365. Id. at 69 . 
constituency will be unable to maximize the long-term market value of the firm. ${ }^{366}$ Indeed, "[s]hort-term profit maximization at the expense of longterm value creation is a sure way to destroy value.,"367

Both the Aspen Institute's Program on Business and Society and the Brookings Institution have sponsored research symposia to examine the purpose of the firm and generate non-technical, student-friendly teaching materials on the subject. ${ }^{368}$ The lead author's ethical business leader's decision tree, originally published in Harvard Business Review ${ }^{369}$ and set forth in Figure 4, provides a tool that students, managers, and lawyers can use to assess the legality and ethics of a proposed business decision.

366. See Michael C. Jensen, Value Maximization, Stakeholder Theory, and the Corporate Objective Function, 14.3 J. APPLIED CORP. FIN. 7, 9 (2001) ("In order to maximize value, corporate managers must not only satisfy, but enlist the support of, all corporate stakeholders-customers, employees, managers, suppliers, local communities.").

367. Id. at 16 .

368. For example, as part of the Aspen Institute's symposia on purpose of the firm, Sally Blout, the Dean of the Kellogg School at Northwestern, has called for a relatively short document that could be circulated to business school deans and faculty to explain the fiduciary duties of directors in a lay-person's terms. Interview by Constance E. Bagley with Judith Samuelson, Head of the Aspen Institute's Center for Business and Society, in New York, New York, on April 26, 2013. Dean Blout describes Kellogg's mission as follows: "Our purpose is to educate, equip and inspire leaders who build strong organizations and wisely leverage the power of markets to create lasting value." Sally Blout, Message from the Dean, http://www.kellogg.northwestern.edu/about/from_the_dean.aspx [perma.cc/ALV5-MAXZ] (emphasis added). A Harvard Business School note written by Carliss Baldwin of Harvard Business School and the lead author has a similar purpose but does not include the latest court cases. Constance E. Bagley, Carliss Baldwin \& John Quinn, M\&A Legal Context: Basic Framework for Corporate Governance, Harvard Business School Note 803-200 (2003). Recent cases can be found in BAGLEY, supra note 293 , at $610-37$.

369. Constance E. Bagley, The Ethical Leader's Decision Tree, HaRv. Bus. Rev., Feb. 2003 , at 19 . 
FiguRE 4: THE ETHICAL BUSINESS LEADER's DECISION TREE

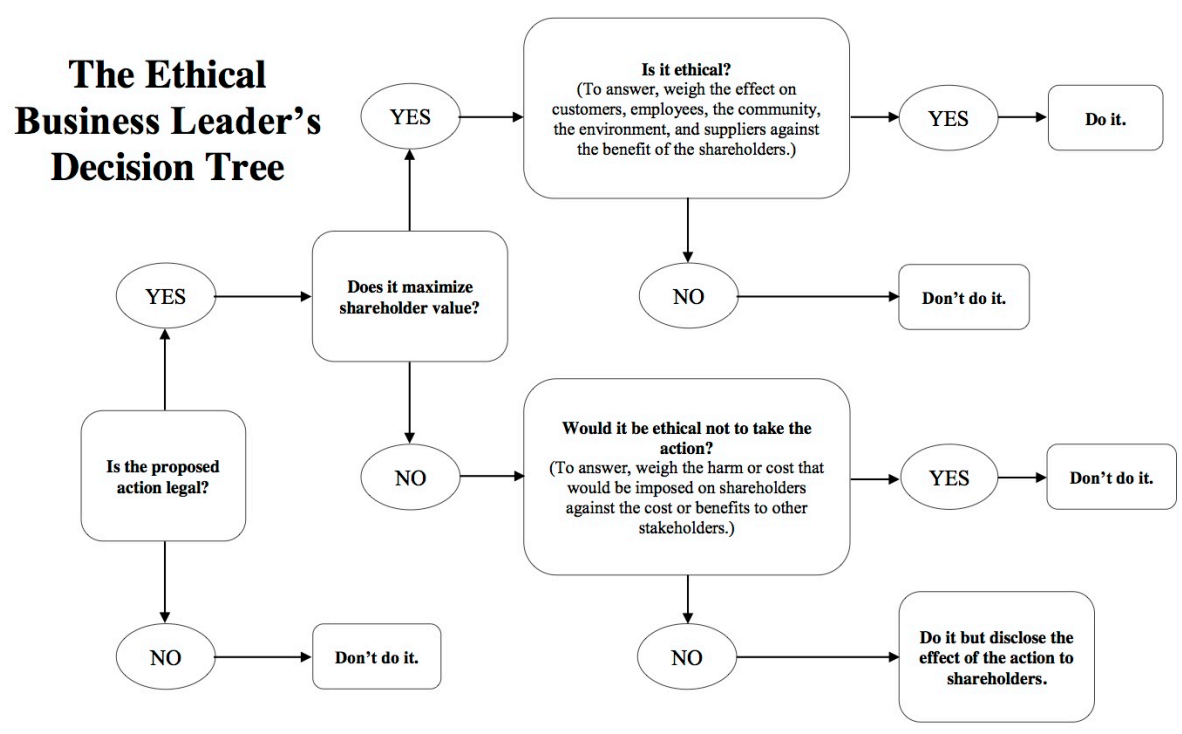

Judicial opinions (especially when excerpted to make them more accessible to business school students ${ }^{370}$ ) and business-school cases based on such opinions ${ }^{371}$ offer business school students rich fodder for analysis and discussion. As the founders of modern business policy and strategy explain, business leaders must ask not only what they can do but also what they should do. In addition, instructors can use so-called Harvard Business School-type cases, which present students with a complicated fact pattern and then require them to play the protagonist and present and defend their proposed solution to the decision at hand, to enhance legal literacy. Often, the best legal studies cases include both business and legal issues so students can practice incorporating legal and ethical considerations into

370. See, e.g., BAGLEY, supra note 293 (containing both excerpted and summarized court cases that are used in business programs at more than one hundred colleges and universities) (publisher adoption list on file with the lead author.).

371. See, e.g., Constance E. Bagley, Meinhard, Salmon, and the Bristol Hotel, Yale School of Management Case No. 07-032 (2007) (addressing the fiduciary duty one joint venture owes another when offered a new opportunity, based on Meinhard v. Salmon, 164 N.E. 545 (N.Y. 1928)); Northeast General (A), Yale School of Management Case No. 07035 (2007) (including discussion questions about whether one party had a right to sue the corporation and what language could have been added to the contract); Northeast General (B), Yale School of Management Case No. 07-036 (2007) (stating that the majority distinguishes Meinhard v. Salmon when holding that a mere finder does not have a fiduciary duty to disclose to his client the unsavory reputation of a potential buyer while the dissenting judge argues that disclosure is both legally and ethically required). 
their managerial analysis. For example, when the leaders at Research in Motion must decide whether to make their BlackBerry encryption codes available to various governments, they must consider both their competitive advantage vis-à-vis competitors like Apple and Google and the varying privacy protections offered in UAE, India, Europe, and Canada, including the historic antecedents. ${ }^{372}$

Although the case method pioneered by Christopher Columbus Langdell at Harvard Law School, which is designed to teach law school students "how to think like a lawyer" by reading and discussing judicial opinions in a Socratic manner, helps prepare future litigators, ${ }^{373}$ it hardly is adequate to train students how to be "transaction cost engineers" 374 and "enterprise architects." 375 For example, "R\&D [is] carried out in a virtual Cambrian explosion of organizational forms," ${ }^{376}$ which are shaped at least in part by business lawyers. Training a student to organize a venture or to do deals by reading court opinions is a bit like training a student to be a physician by reading autopsy reports. It hones analytic skills and is informative of what to avoid but hardly provides practice in crafting

372. Constance E. Bagley et al., Research in Motion: Compromise Blackberry Security, or Give Up Emerging Markets, Yale School of Management Case No. 11-011 (2011).

373. Even that is debatable. As Gillian Hadfield recounted:

Mark Chandler, General Counsel of Cisco Systems Inc., spoke to me about how hard it is to find litigation firms that know how to think about litigation strategy in light of a raft of public and investor relations concerns. He recounted the story of Cisco's litigation with a Chinese competitor that Cisco believed had violated its patent rights. Early in the process his outside litigators recommended filing some pre-trial motions. Chandler asked if they would win those motions. The answer from his expert litigators was no, but those motions can be used to educate the judge about the issues. Chandler's response: "Don't you guys get it? This lawsuit was all over the news the day it was filed. When we lose those motions the headlines the next hour read, "Cisco loses first round to competitor" and the finance guys are going berserk." Chandler wants a litigation team that has expertise in thinking about strategy beyond the courtroom.

Hadfield, supra note 213.

374. Ronald J. Gilson, Value Creation by Business Lawyers: Legal Skills and Asset Pricing, 94 YALE L. J. 239, 255 (1984). For a further discussion of how lawyers create value in transactions, see Steven L. Schwarcz, Explaining the Value of Transaction Lawyering, 12 StAN. J.L., Bus \& FIN. 486, 498-99 (2007) (discussing a hypothesis that transactional lawyers add value by reducing regulatory costs, not by reducing transaction costs or by reducing information asymmetry).

375. George W. Dent, Jr., Business Lawyers as Enterprise Architects, 64 Bus. Law. 279, 289-93 (2009) (explaining that business lawyers organize and reorganize firms; structure joint ventures, licensing arrangements and other strategic alliances; practice preventative law; protect intellectual property; and handle regulatory matters).

376. Ronald J. Gilson, Locating Innovation: The Endogeneity of Technology, Organizational Structure, and Financial Contracting, 110 CoLuM. L. REV. 885, 887 (2010). 
successful outcomes. According to Noll,

The ossification of legal practice that is the theme of Professor Hadfield's article 377 arises from two characteristics of legal education: an orientation towards effective advocacy and an emphasis on basing analysis on parallels with precedent. These features of legal education create a backwards-looking focus on winning disputes rather than a forward-looking focus on innovative solutions to new problems. ${ }^{378}$

For that practice, the Harvard Business School case method is far more effective.

The good news is that the two approaches are not mutually exclusive; they can be used at both law schools and business schools to prepare both future lawyers and future managers to work together more effectively. For example, the lead author prepared a variety of Harvard-style cases while on the faculty at the Stanford Graduate School of Business, the Harvard Business School, and the Yale School of Management, suitable for use at both business schools and law schools. ${ }^{379}$ Court cases, either full-text or excerpted in a law-school casebook, ${ }^{380}$ or, in the case of business school students, excerpted or summarized in a text, ${ }^{381}$ can be coupled with Harvard-style cases and business theory ${ }^{382}$ both to teach legal reasoning and black-letter law and to teach managerial skills and theory. The Harvard Law School has developed a Case Studies Program that supports various "case development projects throughout Harvard Law School.,"383 Harvard's

377. Hadfield, supra note 213.

378. Roger G. Noll, Impediments to Innovation in Legal Infrastructure, 8 I/S: J. L. PoL'Y INFO. SOC. 60, 61 (2012).

379. For a list, including the legal topics addressed, see the tab for business school teaching materials on the entrepreneurship law site sponsored by the Kauffman Foundation entrepshiplaw.org.

380. For a classic treatment integrating law and finance, see VICTOR BRUDNEY \& William W. Bratton, Brudney and Chirelstein's Cases and Materials on CORPORATE FINANCE (4th ed. 1993) (containing examples of full text or excerpted cases).

381. Based on the lead author's experience at Stanford, Harvard and Yale, it is the rare business school student who will devote the time and effort to read multiple full-text legal opinions. She has found that a text that includes both summarized and excerpted cases and "hornbook"-type text is a more effective way to teach business law to business students and executives. See, e.g., BAGLEY, supra note 293 (offering a comprehensive yet understandable legal text for business students); BAGLEY \& DAUCHY, supra note 280 (explaining the various legal stages of starting a business. Business Insider included the third edition of this text in its twenty-five must-read books for entrepreneurs; it is used at more than one hundred business and law schools. The publisher adoption list is on file with the lead author).

382. See, e.g., BRUDNEY \& BRATTON, supra note 380 (containing examples of full text or excerpted cases).

383. Case Studies Program, HARvard LAW School, 
Case Development Initiative creates case studies that are used in Executive Education and law classes on topics that include "career dilemmas that lawyers face and management issues that law firms and professional service firms experience," exposing participants to "real-world problems that lawyers and firm leaders confront, and help them work through possible approaches and solutions." 384

In his class "Introduction to In-House Practice of Law" at the University of Colorado Law School, co-author Roellig uses the business school case study approach instead of the more traditional analysis of court cases used in most law schools. The students, who include both law students and new in-house attorneys, work with case studies based on real fact patterns. They are called upon to evaluate the various options as additional information is provided, just as happened in the real world. Students learn that decisions are not static, but continue to evolve as more facts become available or change. In addition, they learn that both counsel and managers must take into account the interests and likely reactions of many different stakeholders, including regulators. The course gives the students the opportunity to practice exercising "good judgment" 385 and effective decision- making. The discussion of each case study concludes with an overview of how the matter in reality played out, good or bad. His guest speakers have included the general counsel of Cisco, Verizon, Prudential Financial, Clorox, Viacom, Gates and DeVita. An overriding theme of the class is that the right legal answer is not always the right answer for the business. That is, just because something is legal does not mean that it is wise to do it. Even when a lawyer can conclude that a particular position is legal under the current facts and law, the situation can evolve very quickly when viewed under the microscope of societal values and public opinion.

University of Colorado Law School Dean Philip J. Weiser commented:

Today's law students need to learn not only to "think like lawyers," but also to "think like clients." The creative problem solving skills that are associated with in-house lawyers, along with their business skills and knowledge of their business, are core competencies for all lawyers. Thanks to the leadership of Mark Roellig in developing a unique course offering, Colorado

\footnotetext{
http://casestudies.law.harvard.edu/case-studies-program/ (last visited Jan. 31， 2016) [perma.cc/CE3X-NUT8].

384. About Harvard Law Case Studies, HARvard LAW School, http://casestudies.law.harvard.edu/about-harvard-law-case-studies/ [perma.cc/F2W8-Z8LG] (last visited Jan. 31, 2016).

385. See discussion supra Part III.C (defining good corporate judgment).
} 
Law is able to provide our law students with an opportunity to learn from highly accomplished professionals, to use case studies that take them into the board room setting, and to learn alongside in-house lawyers. With the benefit of this course, and complementary programs like our Technology Lawyer Accelerator, we are seeing an increasing number of in-house leaders willing to hire law students to make a positive impact right after graduation. ${ }^{386}$

Legal and strategic astuteness are particularly important in the new economy. According to Hadfield:

Fast-paced, global, niche-driven, and increasingly networkrather than firm-based, the economy today is poorly served by legal markets and institutions developed to meet the demands generated by an economy based on standardized mass-market manufacturing, predominantly domestic markets, and production organized within, rather than across, firm boundaries. Today's legal infrastructure ... is too slow, cumbersome, and complicated (and hence too costly) to manage the explosion in the number and heterogeneity of legal relationships and regulatory settings that characterize today's global web-based entities, facing shorter product (and strategy) lifecycles and fluid business models. ${ }^{387}$

She posits:

"legal infrastructure" - the legal resources available to individuals, organizations, and regulators to help govern relationships-is critical to support and regulate the transformations of the new economy. Legal infrastructure provides important intangible connections-invisible bridgesbetween consumers, suppliers, investors, innovators, and regulators. It includes the formal rules produced by courts and legislators but, more importantly, it also includes the knowledge, practices, norms, and resources of legal practitioners: the solutions and advice provided by lawyers; the procedures of courts and arbitrators; the contract templates stored in public and private databanks; the shared beliefs about liability risks and optimal strategies; the accumulated wisdom and biases of experienced advocates and adjudicators, educators, and negotiators. ${ }^{388}$

As Hadfield explains: "Collectively, these legal resources translate formal

386. E-mail from Philip J. Weiser, Dean, Univ. of Colo. Law School to Mark Roellig, Adjunct Faculty, (Aug. 19, 2015) (on file with the lead author).

387. See Hadfield, supra note 213 , at 8 .

388. Id. at 7 . 
rules into actual behavior and decision making by economic actors." 389

This failure of the legal infrastructure to adapt to the exponential, nonlinear nature of the new economy is particularly problematic in areas such as healthcare, bioscience, genomics, data analytics, energy, and information transmission and exchange. Hadfield attributes this maladaptation in part to "the severe limitations on who may produce legal rules and other legal inputs (such as advice, document templates, norms and practices) imposed by our continued reliance on publicly produced rules and the excessively closed nature of our lawyer- and judge-controlled legal markets." ${ }^{390}$ We agree with Noll that law schools are partially to blame for not adequately training lawyers for the new economy, ${ }^{391}$ but we also fault business schools for not promoting legal literacy and providing future managers the opportunity to practice the exercise of informed judgment. As all of our above observations, critiques, and prescriptions are context-dependent, we now turn attention to non-American contexts and the unifying force of globalization.

\section{GlobALIZATION AND THE CHANGING ROLE OF GENERAL COUNSEL: NEW DATA, PREDICTIONS, AND PRESCRIPTIONS}

This section briefly explores the current and anticipated effects of "globalization" 392 on in-house counsel and their corporate clients. We discuss the changing role of general counsel in the United Kingdom ("U.K."), then present new data on the role of in-house counsel in Sweden. This section concludes by identifying the unwelcome consequences of malfeasance abroad together with the counteracting benefits our concepts of legal and strategic astuteness provide legal practitioners (especially chief legal officers) and managers outside the United States.

The process of globalization occurs iteratively, largely country by country or by group of countries (wherein the United States often leads, followed respectively by phase two, with the U.K., phase three, with Continental Europe, and phase four, with emerging nations). Globalization has acted as a force pushing lawyers in Continental Europe and the socalled BRICs (Brazil, Russia, India and China) to emulate the Anglo-

389. Id.

390. Id. at 2 .

391. Noll, supra note 378.

392. Joseph Stiglitz, Globalization AND its Discontents 9 (2002) (defining "globalization" as "the closer integration of the countries and peoples of the world, which has been brought about by the enormous reduction of costs of transportation and communication, and the breaking down of artificial barriers to the flows of goods, services, capital, knowledge, and ... people across borders."). 
American normative model of legal expertise. ${ }^{393}$

But legal convergence is an evolutionary and non-linear process. In Europe, soft law instruments aimed at harmonization of different legal systems, often elaborated by academic groups, have become increasingly important. They include The Draft Common Frame of Reference $(\text { DCFR })^{394}$ and The Principles of European Contract Law (PECL). ${ }^{395}$ Courts often cite them, causing practitioners and scholars to regard them as sources of law.

Thus, there is a spectrum in which globalization operates that measures the degree to which barriers can or should be broken down. Certain barriers may serve a more beneficial function when preserved than when eliminated. In such cases,

transnationalization preserves the sovereign rights of nations, protecting what could otherwise be broken down in a more globalized regime. The licensing and regulation of attorneys is a case in point.

The European Court of Justice ("ECJ") rejected the idea that in-house counsel can act independently of management when it refused to extend attorney-client privilege to communications with in-house lawyers: ${ }^{396}$

The company lawyer's economic dependence and close ties with the company (i.e., its employer), puts him in a different position to that of the external lawyer according to the ECJ. The ECJ's rationale, following Advocate General Kokott's opinion of 29 April 2010, is that regardless of a company lawyer being registered with a Bar or Law Society and the professional ethic obligations that he is subject to, his position as an employee of the company (and not as an independent lawyer) does not allow him to ignore the commercial strategies pursued by his client, thereby, affecting his ability to exercise professional independence. On this basis, communications between commercial managers and their company lawyers should not be subject to legal professional privilege. ${ }^{39}$

393. Sida Liu, The Legal Profession as a Social Process: A Theory on Lawyers and Globalization, 38 LAW \& SOC. INQUIRY 670, 682-85 (2013).

394. Study Grp. on a EuRopean Civil Code \& ACQuis GRP., PRinciples, Definitions and Model Rules of European Private law, Draft Common Frame of Reference (DCFR): OUTLINE EDITION (Christian von Bar et al. eds., 2009) (ebook).

395. Principles of EUROPEAN CONTRACT LAW: PARTS I AND II (Ole Lando et al. eds., 2000); PrinciPLES OF EUROPEAN CONTRACT LAW: PART III (Ole Lando et al. eds., 2003).

396. Case C-550/07 P, Akzo Nobel Chems. Ltd. v. Eur. Comm'n, 2010 E.C.R. I-08301.

397. Philippe Coen, Introduction to Company Lawyers: Independent by Design, An ECLA White Paper, at 12 (Philippe Coen \& Christophe Roquilly eds., 2012), http://www.ecla.org/files/files/Profession/document1.pdf [perma.cc/RFQ4-2HZR]. 
We agree with the European Company Lawyers Association White Paper "Company Lawyers: Independent by Design," which calls for

a drastic rethinking of the way the legal function should be viewed and considered nowadays in a globalized system where more than ever, the economy needs strong companies and companies cannot survive strongly without a valued and forceful legal function, caring for the compliance and citizenship of the company with a high level of ethics within: the legal department independently minded while remaining a management business partner and close advisor. ${ }^{398}$

As Chayes and Chayes chronicled happening earlier in the United States: ${ }^{399}$

Company lawyers have developed their influence via innovation.

Company lawyers have learnt how to be more present and visible, they have improved their ability to innovate and be creative with leadership, they have improved their interacting skills, their self recognition into strong ethical values and they have enhanced their image of trust and accountability. ${ }^{400}$

We agree with the following characterization of in-house counsel's capacity to work with managers to ensure firms win with integrity, but we caution that unchecked entrepreneurialism can impede it:

They [company lawyers] are committed to appear trustworthy not only as lawyers but also as leaders. Company lawyers are the ones creating internal policies, soft laws, codes of conduct: they have no other choice to act with care, confidence and wisdom which are the prolegomenon of independency. Indeed, integrity is a natural skill among our profession as this is the way we ought to be identified within the company and within the society in general. Integrity is the attribute of independency; it is the bread and butter of a company lawyer's everyday practice: setting the example, always. Leading a life of integrity and independency is neither an obstacle nor a burden, it's an outlook. We can be optimistic to believe that all lawyers, company lawyers included, share that outlook and we can be trustful that such an outlook towards independence is by itself a professional and philosophical emulation. Independency and objectivity as part of ethics are part of our DNA; and far from being a burden they constitute the rewards of the company lawyer's profession. Company lawyers are not employees like any other. Because of

398. Id.

399. Chayes \& Chayes, supra note 86.

400. Coen, supra note 397, at 12-13. 
their training, because of their ethics, because of their professional rules, because of their specific approach to things and issues, it's time to show that company lawyers can make a difference and self-assert that difference. ${ }^{401}$

Finally, we believe the attorney-client privilege should also apply to inhouse counsel. Although the roles can be different, in-house and outside counsel have the same legal and ethical obligations; their clients should be afforded the same protections and privilege to provide for candid communications and ensure proper legal counsel. ${ }^{402}$

\section{A. The Anglo-American Nexus}

Originally characterized by American dominance and leadership, the Anglo-American legal nexus ${ }^{403}$ is now more accurately characterized by national parity (albeit delayed). ${ }^{404}$ John Flood argues that significant differences in each nation's legal context account for the initial disparity in the nations' respective global legal prominence, namely (1) U.K. solicitors' relative lack of litigation experience, (2) U.K. law firms' relative lack of a large domestic legal market, (3) U.K. law firms' relative lack of strong and longstanding ties with globally known financial firms with which to partner in legal transactions, and (4) U.K. law firms' relative lack of established foreign office locations. ${ }^{405}$ Recent changes in the British legal infrastructure, however, diminish this disadvantage and place "U.K. firms ... now on par with U.S. firms." ${ }^{\text {no6 }}$ They include (1) limited reform allowing solicitors some ability to appear in court unaccompanied by barristers; (2) the Legal Services Act ("LSA") of 2007, ${ }^{407}$ allowing lawyer and even non-lawyer ownership of U.K. law firms to inject them with capital and promote their global competitiveness; and (3) the recent longterm rally of the U.K financial sector. ${ }^{408}$ It is very possible that this

401. Id. at 13 .

402. Bagley \& Roellig, supra note 212 , at 120.

403. John Flood, Lawyers as Sanctifiers: The Role of Elite Law Firms in International Business Transactions, 14 Ind. J. Global Legal StUd. 35, 54 (2007).

404. See John Flood, Institutional Bridging: How Large Law Firms Engage in Globalization, 36 B.C. INT'L \& COMP. L. REV. 1087, 1090 (2013) (“[U.K. law firms] are now on par with U.S. firms.").

405. Id. at 1089-93.

406. Id. at 1090 .

407. Id. at 1098 .

408. Job openings in London's financial sector increased $18 \%$ in 2014, due in part to a $22 \%$ increase in the last quarter of the year, "the biggest increase since 2010." Ambereen Choudhury, London Finance Job Vacancies Jumped 18\% in 2014, BLOOMBERG Bus. (Jan. 4, 2015), http://www.bloomberg.com/news/articles/2015-01-05/london-finance-job- 
injection of investment and venture capital may drive efficiencies and innovation that will advantageously disrupt law, to the benefit of clients and consumers. The failure of other legal systems to do this, including in the United States, could cause a competitive disadvantage since such systems will not benefit from these innovations and efficiencies. The nexus draws strength from several international commonalities, including (1) a shared use of the common law system, the legal system most widelyused and most conducive to the ad-hoc, fluid nature of globalization; (2) strong, globally-preeminent financial centers; (3) an ability to think locally but operate globally; and (4) their longstanding tradition of engaging in transnational legal transactions. ${ }^{409}$

\section{B. In-House Counsel in Sweden}

If globalization scholars are correct, and general counsel in Continental Europe and the BRICs follow the American-Anglo model of general counsel, then we can expect these counsel to confront the moral hazards posed by Nelson and Nielsen's American entrepreneurial lawyer, making our prescriptions applicable to the global context. The globalization scholarship offers few data on this issue. To help fill this gap, we present here an original study of the role of general counsel in Sweden.

Sweden is a small Scandinavian country with a population of more than nine million people, marked by its international neutrality, broad social welfare, and export-powered wealth. ${ }^{410}$ Sweden remained neutral during both World Wars, which allowed the country to avoid the major reconstruction periods during twentieth century Europe. It became a major exporter due to the trade barriers between nations involved in these wars. Since the conclusion of World War II through the present day, the Swedish economy has been dependent on its openness and trade.

Currently a little less than half of Sweden's GDP is from exports, compared with about $13 \%$ for the United States. ${ }^{411}$ Sweden primarily exports refined petroleum, medicine, phones, vehicles, and vehicle parts. ${ }^{412}$

\footnotetext{
vacancies-jumped-18-in-2014-astbury-says [perma.cc/D9G7-KRJP].

409. Flood, supra note 404, at 1089-97.

410. See Sweden in Figures, EXPORT.GOv, http://www.export.gov/sweden/doingbusinessinsweden/swedeninfigures/index.asp [perma.cc/BL3Y-QZ2Q] (last updated Mar. 21, 2011) (listing facts about Sweden); Sweden Population 2015, WORLDPOPULATIONREVIEW, http://worldpopulationreview.com/countries/sweden-population/ [perma.cc/P83X-X9QQ] (last visited Jan. 31, 2016) (detailing Sweden's population).

411. 4.8 World Development Indicators: Structure of Demand, WORLD BANK, http://wdi.worldbank.org/table/4.8 (last updated Oct. 9, 2015).

412. Alex Simoes, Sweden, The ObSERvatory of Econ. Complexity,
} 
Their main customers are located in Western and Northern Europe in addition to the United States and China. ${ }^{413}$ Sweden has a highly concentrated banking sector, with the four largest banking groups (Nordea, Svenska Handelsbanken, Swedbank, and SEB) accounting for $80 \%$ of the assets. ${ }^{414}$ About $70 \%$ of the Swedish labor force is unionized. ${ }^{415}$ As of 2014, of the 4.59 million Swedish employees, about 3.79 million are in the service industry. ${ }^{416}$ For its size, Sweden has a bevy of varied successful companies, including ABB Ltd., AstraZeneca, Ericsson, Skanksa, H\&M, and Spotify, which have found success in engineering, pharmaceuticals, communication technology, construction, retail, and media, respectively.

Sweden's legal market has not kept pace with its corporate achievements. Only the largest twenty-three of the top fifty Swedish law firms have more than fifty lawyers; only thirteen law firms have more than one hundred attorneys. ${ }^{417}$ Sweden has a liberal definition of lawyers. Any individual may legally practice law, without the need for a formal legal education or admission to the bar. ${ }^{418}$ In addition, anyone may represent himself or herself or another litigant in any court in Sweden. ${ }^{419}$ Sweden does, however, have a bar called the Swedish Bar Association (Sveriges advokatsamfund), which was formed in $1887 .{ }^{420}$ The members of the Swedish Bar Association have a legally protected exclusive right to call themselves "advokat"; thus, although anyone can potentially represent litigants, it is typically the advokats who are the legal representatives in court. $^{421}$

The Swedish Bar Association prohibits in-house lawyers from

http://atlas.media.mit.edu/profile/country/swe/ [perma.cc/5TF2-TUFL] (last visited Jan. 31, 2016).

413. Id.; Sweden in Figures, supra note 410.

414. List of Banks in Sweden, BANKS SWEDEN, http://bankssweden .com (last visited Jan. 31, 2016) [perma.cc/LEB9-ESXL].

415. Working in Sweden: Workers' Rights and Unions, SwEDISH INS., http://work.sweden.se/living-in-sweden/workers-rights-and-unions/[perma.cc/C6VW-63ZG] (last visited Dec. 29, 2015).

416. Employment by activities and status (ALFS), OECD, http://stats.oecd.org/index.aspx?queryid=9185 [perma.cc/RQM2-F36K] (last updated Nov. 7, 2015).

417. Friederike Heine, Sweden: It all goes around again, LEGALWEEK (Apr. 15, 2010), http://www.legalweek.com/legal-week/analysis/1601229/sweden-it-goes [perma.cc/J93JXJTS].

418. The Swedish Bar Association, 46 Scandinavian Stud. In Law 323, 323 (2004).

419. Id.

420. About Us, SwEDISH BAR ASS'N, https://www .advokatsamfundet.se/Advokatsamfundet-engelska/About-us/ [perma.cc/YY4XLHYZ] (last visited Jan. 31, 2016).

421. The Swedish Bar Association, supra note 418, at 324. 
becoming members of the Bar Association. ${ }^{422}$ To become and maintain their title, advokats must work for, or form a company with another adovkat. $^{423}$ This required separation from non-legal management "is seen as a corner stone of professional independence." ${ }^{424}$

The Swedish Bar Association has been moving towards a less restrictive club. Effective January 1, 2011, the Bar Association changed the rules of admission to the bar from a five-year to three-year requirement of practice following graduation from law school. ${ }^{425}$ A desire to help Swedish attorneys remain competitive with their counterparts from other European jurisdictions motivated this change. ${ }^{426}$

In 2010, the Swedish Company Lawyers Association administered an electronic questionnaire (the "Swedish Survey"), prepared by the lead author, Christophe Roquilly of ADHEC Business School in Nice, France, and Boel Flodgren of Lund University, to the Association's 900-plus members. The Swedish Survey included forty-six questions centering on the roles each corporation's in-house lawyers ("IHLs") play in the Continental European context. ${ }^{427}$ There were seventy-nine responses to many questions, but only sixty-seven respondents answered all questions. All percentages were based on the number of respondents answering that question. Although participant companies requested anonymity, they represented a wide swath of Sweden's most prominent companies in terms of name recognition, overall size, and revenue. Annual revenues ranged from $€ 5$ million to $€ 50$ billion, with thirty-four of the seventy-nine total respondent companies generating more than $€ 1$ billion in annual revenues in various industries, including financial services, telecom, medical equipment, software, engineering, energy, food, and media. Of the respondent companies, 55\% were more than fifty years old, with $35 \%$ eleven to fifty years old, and $11 \%$ were ten years old or younger.

The number of IHLs worldwide ranged from one to 411 , with $11 \%$ of the 79 Swedish respondent companies employing one IHL, 46\% employing two to ten, $20 \%$ employing eleven to thirty, $6 \%$ employing thirty-one to fifty, and $14 \%$ employing more than fifty-one IHLs. The number of IHLs based in Sweden ranged from zero to thirty, with $73 \%$ of the Swedish

\footnotetext{
422. Id. at 323 .

423. Id.

424. Id.

425. INT'L BAR Assoc., Professional Qualifications for the Legal Profession in Sweden, BAR ISSUES COMMISSION (July 27, 2011), http://www.ibanet.org/Document/Default.aspx?DocumentUid=339B706D-B166-4644BD67-C8E5477876D7 [perma.cc/9NCZ-UP6Q].

426. Id.

427. The text of both the survey and the cover letter are on file with the lead author.
} 
respondents reporting two to ten IHLs in Sweden. Fifty-six percent of the Swedish respondents reported that the first IHLs were hired ten to fifty years ago, with $33 \%$ being hired less than ten years ago, and $11 \%$ more than fifty years ago.

Twenty-eight percent of the Swedish respondents reported that they had hired thirteen or more outside law firms in the last calendar year, with $25 \%$ hiring four to six, $20 \%$ two to three, $13 \%$ ten to twelve, $10 \%$ seven to nine, $3 \%$ one, and $1 \%$ none. Of the seventy Swedish respondents, $19 \%$ agreed that non-lawyers in their firm communicate directly with outside lawyers; $19 \%$ were neutral; $64 \%$ disagreed or strongly disagreed. ${ }^{428} 57 \%$ of the seventy respondents agreed or strongly agreed that the outside lawyers understand the hiring firm's business; 20\% were neutral; and 23\% disagreed or strongly disagreed.

The data collected in the Swedish Survey echo Nelson and Nielsen's central findings regarding American lawyers ${ }^{429}$ namely that lawyers tend to act as counsel (providing both legal advice) most often, with $75 \%$ of the seventy-one Swedish respondents characterizing their role as lawyer, followed by entrepreneur $(21 \%)$, and finally cop (4\%). ${ }^{430}$ Fifty percent of the American lawyers surveyed by Nelson and Nielsen self-identified as counsel, $33 \%$ as entrepreneurs, and $17 \%$ as cops. ${ }^{431}$ Of the 71 Swedish respondents, $68 \%$ strongly agreed that their IHLs were "service oriented"; $17 \%$ agreed with this characterization; and $3 \%$ were neutral.

Asked to identify "a primary mission of the legal department," with any or all of the following six choices available, the seventy-one Swedish responses yielded means on the five-point Likert scale for the various choices as follows:

- To reduce legal risk: 4.62

- To advise the rest of the company on legal matters: 4.45

- To propose solutions in order to make easier or to achieve the completion of a project: 4.28

- To contribute to value creation by the company: 4.28

- To reduce business risk: 4.06

428. Here and elsewhere numbers may add up to more than $100 \%$ due to rounding.

429. Nelson \& Nielsen, supra note 109, at 464-65.

430. The text of both the survey and the cover letter are on file with the lead author.

431. Nelson \& Nielsen, supra note 109, at 468. 
- To ensure legal compliance: 3.94 .

Asked to rank order-from one for the most frequent to four for the least frequent - four descriptions of what IHLs are most often called upon to do, $90 \%$ of the seventy-one respondents ranked first responding to legal queries with legal advice; $6 \%$ ranked proposing new legal solutions second; $4 \%$ ranked anticipating the needs of managers third; and $65 \%$ ranked helping formulate business strategy fourth. Of the seventy-one respondents, $44 \%$ ranked serving on integrated project teams as the most frequent structure for their work; $42 \%$ ranked working with specific business units on a permanent basis second; and 39\% ranked focusing on legal issues in an independent and autonomous way third.

When asked to indicate any or all of four descriptions of their company's political lobbying activities, 54\% of the seventy-one Swedish respondents indicated that their firm lobbies in anticipation of specific proposed legislation or proposed regulations; $44 \%$ in response to specific enacted legislation or promulgated regulations; $31 \%$ not at all; and $28 \%$ to shape public policy regardless of what legislation or regulation is pending. Of the seventy-one respondents, $51 \%$ work with trade or industry associations to advocate for their political interests; $37 \%$ prepare position papers or technical reports; $35 \%$ engage in face-to-face meetings with regulators (state or federal); $34 \%$ indicated that they do not engage in any political lobbying activities (which is at odds with the $31 \%$ answer described immediately above); $7 \%$ hire outside counsel with political lobbying experience; $7 \%$ conduct press conferences; and $1 \%$ acts as experts in legislative work.

Sixty-four percent of the Swedish respondents indicated that their firm has a legal culture. Descriptions varied:

- "[A]merican blame culture"

- "Do more or less everything legal"

- "Re legal culture: there is a relatively broad awareness amongst the managerial top layers of the legal matters policy in place (which contains the fundamental principals [sic] for the involvement by the legal department). This is however still not the case further down the organization."

- "It is pretty well established when to turn to the legal department and in my opinion this works very well most of the time" 
- "It is based on a fundamental respect for the law and understanding that the risk we as a firm wish to take on should be well analyzed and defined. Risk should as principle not come from the structure of our transactions, but from the market we choose to expose our assets against"

- "Legal and regulatory integrity and trust is [sic] an instrumental part of value creation"

- "It is not a goal to live up to our rules, it is the first step."

The Swedish data echo Nelson and Nielsen's findings concerning American in-house counsel, namely, that their practice primarily centers on a mix of law and business. ${ }^{432}$ Ninety-six percent of the seventy-one Swedish respondents strongly agreed or agreed there was an expectation that IHLs understand the fundamentals of the business; $4 \%$ were neutral, yielding a mean of 4.65 on a one to five point Likert scale. As one Swedish respondent put it: "The services of the IHLs are integrated into the system of operation on all levels, business, strategy, finance, compliance and so on and so forth." This set of expectations could explain why most lawyers see themselves as operating within a middle space between the cop and entrepreneur models.

The role of IHLs in Sweden in developing strategy and the close ties with the top management team parallel Nelson and Nielsen's finding of entrepreneurialism in American counsel. Notwithstanding the fact that a majority of Swedish counsel self-identified as fitting the counsel model, Swedish companies reportedly consider their lawyers to be strategic partners rather than solely cops or gatekeepers. Of the 75 respondents, $85 \%$ reported that most business managers view lawyers as a "partner in value creation," with only $15 \%$ characterizing them as a "necessary evil." One Swedish respondent commented:

I have 8 years of experience as IHL and member of executive team working in an environment with constant crisis. Under these circumstances it is vital to stay within the legal environment but also for the IHL to be hands on and help the company find a solution rather than to point out obstacles.

With respect to the role of the lawyers in the formulation of strategy, $60 \%$ of the seventy Swedish respondents strongly agreed or agreed that lawyers are involved in the formation of strategy, $16 \%$ responded negatively, and $24 \%$ were neutral.

432. Id. at 466 . 
Of the seventy-nine Swedish respondents, 58\% reported that the head of the legal department is a member of the TMT. One respondent explained:

[I]n many old Swedish industrial companies (including my company) the General Counsel are not a natural member of the Group Management team. Both I and my predecessor have under a long time argued for that [sic] the General Counsel should be a member, as it underlines the importance the company puts on legal compliance and that legal aspects are considered when forming the company's strategy.

For reference, Nelson and Nielsen found that $26 \%$ of the general counsel of the U.S. respondents were members of the TMT. ${ }^{433}$ Sixty-seven percent of the Swedish respondents indicated that the head of the legal department reported to the CEO, with $22 \%$ reporting to the chief financial officer, $3 \%$ to the corporate secretary, and $9 \%$ reporting to others.

Some of the data we collected raise concerns about Swedish attitudes toward compliance. For example, when asked whether "complying with the legal rules is seen by business managers as essential to financial success," only $69 \%$ of the seventy-five Swedish respondents strongly agreed or agreed, $27 \%$ were neutral, and $4 \%$ disagreed. Only $61 \%$ of Swedish respondents reported having a control and compliance function. Of the firms that do have a control and compliance function, it is part of the legal department in 56\% of the responding firms. For example, one Swedish respondent stated: "Re compliance: There is today no general compliance department, but instead a department for financial internal control. This is not part of the legal department."

When asked to select one of four characterizations of their firm's approach to regulatory and legal compliance, $36 \%$ of the sixty-seven Swedish respondents selected "Normative (compulsory instructions)"; $28 \%$ selected "Advisory (suggestions, recommendations)"; $27 \%$ selected "Normative with internal controls (compulsory instructions \& audit)"; and 9\% selected "Normative with penalties (compulsory instructions \& audit \& penalties)." When asked to indicate all the listed ways by which the respondent Swedish companies promote regulatory and legal compliance, $79 \%$ of the sixty-seven respondents selected "Adopting a good practices code, an ethical charter or equivalent document specific to the company"; $70 \%$ selected "Offering training by IHLs or courses taught by IHLs for some or all of the employees"; $48 \%$ selected "Distributing interna[1] memos prepared by IHLs on rules to respect"; and 30\% selected "Providing an employment manual or similar booklet to every employee." In response

433. Id. at 494 . 
to the question, "Who spreads and promotes the legal policy in your company (select all that apply)?," 90\% of the sixty-seven Swedish respondents selected the head of the legal department; $31 \%$ selected the $\mathrm{CEO}$; and $15 \%$ selected the CFO; $3 \%$ selected the non-executive chair of the board. For the $12 \%$ selecting other, the answers included: "Our CSR policy is promoted by the Information Department," all IHLs, compliance officer, and local GMs.

Of the sixty-seven respondents, $7 \%$ reported that non-lawyers in their company have no access to legal information $45 \%$ reported ongoing access under the control of the legal department; $43 \%$ reported limited access under the control of the legal department; and $25 \%$ reported unlimited access (for example, a legal intranet) with a possibility to contact IHLs in order to obtain further information. ${ }^{434}$

Only $69 \%$ of the seventy Swedish respondents agreed or strongly agreed with the statement: "In my company, the board of directors expects the head of the legal department to alert it to highly risky choices by management"; $25 \%$ disagreed; and 6\% were neutral. Also troubling is the fact that $30 \%$ of Swedish respondents either strongly agreed or agreed that their CEO would make an important decision without first consulting with counsel; $13 \%$ were neutral; and only $47 \%$ disagreed or strongly disagreed.

In response to the statement, "Business managers in my company tend to structure a deal then bring in the lawyers to document it," only $30 \%$ of the seventy-one Swedish respondents strongly disagreed or disagreed; $31 \%$ were neutral; $38 \%$ agreed or strongly agreed. Of the seventy Swedish respondents, 57\% reported: "In my company, the approval documents for most important projects have a place where IHLs can express their opinion (disagreement, agreement, or caution); $21 \%$ were neutral; and $21 \%$ disagreed or strongly disagreed. Even in Swedish firms without such a formal mechanism, respondents reported various "other mechanisms (formal or informal) whereby IHLs can express their opinion," including:

- "There is no requirement that major contracts (i.e. with a contract amount exceeding 500 KEUR) have to be approved or commented by a LHI [sic]. However, there is a policy that recommend[s] the business people to let a LHI [sic] review any contract above that amount or if the contract is of a complicated nature."

- "In the day to day business when meeting/working with managers and management teams"

434. Percentages exceed $100 \%$ because respondents were asked to select any or all of the four answers that applied. 
- "In various business meetings"

- "Informal personal meetings"

- "Informally through the physical position in the building (office next to the CEO) .... [sic]"

- "When being consulted by management in [sic] specific issues, at our Executive Group Management meetings (consisting of top management and the Heads of Business Areas)"

- "Short track to the CEO and CFO, participation in management meetings, early participation in M\&A projects and other important business projects"

- "Most of the IHLs participate at management forums (such as subsidiary company management meetings) within their respective field of responsibility. The very reason behind this is to provide the IHL with the means to influence."

- "Most important projects are discussed in the management group where head of legal is present"

- "As member of the Group Management team where all issues of this nature is [sic] presented and decided upon"

- "Normal practice in our company to have lawyers on board [o]n all important projects"

- "All agreements are subject to a delegation of authority. All agreements meeting certain criteria must be reviewed. All major projects need a lawyer assigned. No formalized process."

The two Swedish responses best evidencing the proactive element of legal and strategic astuteness were:

- "All legal documents as well as actions shall be approved by IHL on [sic] beforehand. A[n] IHL in this case is very much involved with business on top level, the job is normally done before it becomes a legal document or action."

- "IHLs play an integrated role in the formation of business opportunities as well as the execution of projects." 
Although $30 \%$ of the sixty-seven Swedish respondents either strongly agreed or agreed that the "top management team in my company uses law as a strategic tool to create, protect, grow, and capture value," only $35 \%$ of the respondents strongly agreed with the statement that the "CEO of my company understands the laws and regulations most important to our business." Fifty-two percent agreed, 9\% were neutral, and $4 \%$ either disagreed or strongly disagreed. Given the pervasive role the law plays in both shaping the regulatory environment and providing tools for value creation, the marshaling of resources, and the management of risk, this apparent lack of legal literacy is troubling.

These findings and a number of major Swedish corporate scandals that have occurred within the last fifteen years are early warning signs that call for attention. Although the focus of blame for corporate wrongdoing has not been on the outside lawyers or in-house counsel, but on the directors of the board and the auditors of these Swedish firms, they invite Judge Sporkin's famous question: "Where were the lawyers?"435 Among the scandals - well known in Sweden and in some cases also on the European scene-are the ones involving Skandia, Prosolvia, HQ Bank, and TeliaSonera.

In the first years of this millennium, the bonuses for management at the large Swedish insurance company Skandia were tied to the share price, which skyrocketed as a result of accounting methods based on a faulty valuation. ${ }^{436}$ The CEO was forced out and prosecuted but eventually found not guilty on appeal. ${ }^{437}$ The board resigned ${ }^{438}$ after heavy criticism for lack of appropriate and effective internal controls, and the main auditor was reprimanded by the disciplinary board for auditors. The value of the Skandia shares decreased substantially and Skandia-an old, very respected Swedish insurance company-was taken over by the South African insurance company Old Mutual. ${ }^{439}$ Several legal proceedings

435. Lincoln Sav. \& Loan Ass'n v. Wall, 743 F. Supp. 901, 920 (D.D.C. 1990); Guttman \& Sporkin, supra note 67.

436. Skandal, EcONOMIST (Dec. 4, 2003), http://www.economist.com/node/2273049; Sweden: Special Investigation into Certain Practices of Skandia Insurance Company (Ltd), MONDAQ.COM, http://www.mondaq.com/x/23663/http://www.mondaq.com/x/23663/

Special+Investigation+Into+Certain+Practices+Of+Skandia+Insurance+Company+Ltd [perma.cc/W4TM-89NC] (last updated May 18, 2004).

437. Michael J. Jones, Creative AcCounting, Fraud AND InTERnAtional AcCounting Scandals 533 (2011); Ex-Skandia Boss Cleared, LoCAL (SE) (Dec. 19, 2007, 11:20 AM), http://www .thelocal.se/20071219/9452 [perma.cc/2E8R-284M].

438. Skandia: “A Bit More Down to Earth”, Bloomberg Bus. (Dec. 14, 2003), http://www.bloomberg.com/bw/stories/2003-12-14/skandia-a-bit-more-down-to-earth [perma.cc/FS4Z-2Q5C].

439. Old Mutual Seals Deal for Skandia, BBC News (Jan. 26, 2006, 20:15 GMT), http://news.bbc.co.uk/2/hi/business/4652406.stm [perma.cc/A3CG-EAPJ]. 
ensued. ${ }^{440}$

After the information technology company Prosolvia abruptly lost all its value in 1998, the Appellate Court imposed liability on the main auditor for damages amounting to sums never heard of before in Sweden, where damage awards tend to be much lower than those in the United States. ${ }^{441}$ The government terminated HQ Bank's right to carry on business as a result of unethical trading in financial instruments. ${ }^{442}$ Management's and the board of directors' liability is now being tried in court. ${ }^{443}$

In 2011, the large partly government-owned Nordic telecommunications company TeliaSonera was accused of bribing the leaders of the dictatorship of Uzbekistan with billions of Swedish crowns (US \$337 million) to secure a $3 \mathrm{G}$-license in that country and a stake in the Uzbec company Ucell. ${ }^{444}$ TeliaSonera is the largest publicly traded firm in Sweden. ${ }^{445}$ In 2013 CEO Lars Nyberg and directors of the Board had to resign; ${ }^{446}$ as of 2015 , legal investigations of these actors were ongoing. ${ }^{447}$

Swedish regulators, bar, and judicial officials and in-house lawyers would do well to heed America's cautionary tale by preemptively addressing issues that Americans addressed ex post facto. Even generally

440. JONES, supra note 437.

441. Id. at 363-65; Bo Thomaeus, € 230 Million Award in Landmark Case on Auditor's Negligence, INT'L LAW OFFICE (Sept. 30, 2013).

442. Dominic Chopping, Sweden's HQ Investment Bank Faces Liquidation, WaLl ST. J. (Aug. 31, 2010), http://www.wsj.com/articles/

SB10001424052748703369704575461083275122508 [perma.cc/U3Q5-JPJR].

443. Patrick Lannin, Carnegie Buys Troubled Swedish Bank HQ for $\$ 37 \mathrm{mln}$, REUTERS (Sept. 3, 2010), http://www.reuters .com/article/2010/09/03/

hq-idUSLDE6820K220100903 [perma.cc/YX9A-XBC4].

444. Joanna Lillis, Uzbekistan's First Daughter Accused of Pocketing \$1bn in Phone Deals, GUARDIAN (Mar. 24, 2015), http://www .theguardian.com/world/2015/mar/24/

gulnara-uzbekistan-daughter-corruption [perma.cc/M35J-LK6N]; Uzbekistan's Gulnara Karimova Linked to Telecoms Scandal, BBC News (Nov. 27, 2012), http://www.bbc.com/news/world-asia-20311886 [perma.cc/E6B4-KVKK].

445. Ola Westerberg, The TeliaSonera Scandals: A Swedish Trauma, Organized CRIME AND CORRUPTION REPORTING PROJECT (May 29, 2015), https://www .occrp.org/corruptistan/azerbaijan/azerbaijan-telecom/the-teliasonera-scandalsa-swedish-trauma.php [perma.cc/UWG6-6VK2].

446. Lillis, supra note 444; TeliaSonera CEO Quits amid Bribery Scandal, LOCAL (SE) (Feb. 1, 2013, 11:19 GMT+01:00), http://www.thelocal.se/20130201/45950 [perma.cc/VE5Z-WD6Q] (last visited Jan. 31, 2016). Although TeliaSonera CEO Nyberg denied breaking the law, he conceded that "we should not have gone ahead without learning more about the identity of our counterparty." Id.

447. Lillis, supra note 444. At the annual general meeting of TeliaSonera in 2014, the new board chair Marie Ehrling stated that a report from the international law firm Norton Rose Fulbright had concluded that "TeliaSonera was guilty of unethical, if not criminal, practices in five countries beside Uzbekistan: Azerbaijan, Kazakhstan, Georgia, Nepal and Tajikistan." Westerberg, supra note 445. 
speaking, it is important to remember that general counsel and other IHLs are unique members of the legal community in that they have a single client, the employing corporation, which already could cast doubt on the counsel's ability to dispassionately serve their clients. ${ }^{448}$ Accordingly, Sweden should consider enacting legislation mirroring Section 307 of the SOX $^{449}$ and Rule 1.13 of the American Bar Association's (ABA's) Model Rules of Professional Conduct, ${ }^{450}$ which require general counsel to report material violations of law by their companies "up-the-ladder." 451 Implementing such legislation would help ensure that Swedish boards of directors are not blind-sided by any illegal activity occurring within their corporations.

\section{The Application of Our Prescriptions Outside the United States}

We submit that legal and strategic astuteness are as important for inhouse lawyers outside of the United States and their clients as they are for U.S. companies. In fact, they are especially needed in non-U.S. jurisdictions where the moral hazards posed by Nelson and Nielsen's entrepreneurial lawyer exist but are not yet tempered by legislation or professional norms.

The U.K presents the next most readily applicable context for our prescriptions. Despite the national parity we discussed within the AngloAmerican nexus, the U.K. still lags behind the United States in certain key respects, including the evolutionary state of its general counsel. The rationale behind the LSA of 2007 evidences this lag in its attempt to boost the U.K. legal market's global competitiveness against its only real competitor-the U.S. legal market. It aims to do so by permitting U.K. law firms to accept foreign investment capital from foreign lawyers and nonlawyers alike. In many ways, this action goes beyond the American experience. To wit, when confronting the same option, the "New York State Bar Association has determinedly come out against such moves for New York lawyers and firms, to the chagrin of the large New York City law firms." "452 Unlike in the U.K., such moves constitute "heretical changes

\footnotetext{
448. The European Court of Justice identified this as a key reason to deny communications with in-house lawyers attorney-client privilege. Case C-550/07 P, Akzo Nobel Chems. Ltd. v. Comm'n, 2010 E.C.R. I-08301. See also DeMott, supra note 83, at 956 ("[A] general counsel's dependence on a single client may call into question counsel's capacity to bring an appropriate degree of professional detachment to bear.").

449. Pub. L. No. 107-204, 15 U.S.C. § 7245 (2003).

450. Model Rules of PROF’L CONDUCT, R. 1.13 (2013).

451. Kim, supra note 55, at 1040.

452. Flood, supra note 404, at 1120.
} 
to [the] American legal tradition." 453 This response suggests that Nelson and Nielsen's entrepreneurial lawyer may be waning in the American context in the wake of SOX while it waxes in the U.K. context, poised to create compliance problems in the future. Indeed, although "[1]arge UK law firms have not been affected [by the LSA] yet,

[a]t some point in the future, possibly within the next five or ten years, larger U.K. firms will be attracted to external financing or taking the firm to market in an initial public offering. Then the U.K. firms will have a significant advantage over the U.S. firms. Furthermore, this will give them considerable benefits in the global market. We only have to look at the success of the big accounting firms to see how this could be achieved. ${ }^{454}$

Law firms, however, are not and should not be like accounting firms; likewise, lawyers are not and should not act like accountants. If either were, the legal profession would stand in danger, as Dean Kronman warns, of losing its soul; ${ }^{455}$ lawyers would cease being officers of the court and would strip themselves of the noble ethical standards to which the lawyerstatesman ideal holds them. They would become entrepreneurial lawyers - - the ideal's current professional antithesis.

At the partner level of international law offices in developing countries, "expatriates or local nationals with extensive work experience in the firms' home countries (e.g., Britain or the United States) far outnumber homegrown lawyers." ${ }^{456}$ This suggests that globalizing forces transform and supersede the local diversity these countries' legal cultures would otherwise offer in what some scholars dub a form of Schumpeterian "creative destruction." localization.

Consider India, which is both a representative and exceptional BRIC nation. Many scholars consider India "an ideal site to study the effects of globalization on lawyers" ${ }^{\text {"58 }}$ because of its exceedingly dynamic legal environment. While its strong economic development indicators make it a rising star on the global stage of emerging nations, ${ }^{459}$ it has historically

453. Id.

454. Id.

455. KRONMAN, supra note 120.

456. Liu, supra note 393, at 686.

457. Id. at 682 .

458. Mihaela Papa \& David B. Wilkins, Globalization, Lawyers, and India: Toward a Theoretical Synthesis of Globalization Studies and the Sociology of the Legal Profession, 18 INT'L J. LEGAL. PROF. 175, 176 (2011).

459. Geoffrey Smith, It's Official (Sort of): India to Overtake China as Fastest-growing Major Economy, FoRTUNE (Feb. 27, 2015),

http://fortune.com/2015/02/27/its-official-sort-of-india-to-overtake-china-as-fastest- 
taken a protectionist stance on issues affecting the integrity of its legal profession by "preclud[ing] foreign law firms from practising locally." 460 Notwithstanding India's protectionist stance, "foreign lawyers ... [work] in India on a regular basis ... [thereby] creating regulatory questions that the large law firms have to discuss with Indian legal regulators." ${ }^{\text {"61 }}$ These discussions may be the means by which the Indian legal profession progressively acquiesces in the globalizing forces it now resists. Although most native Indian lawyers are general practitioners who lack specialization (they "remain as courtroom litigators and are rarely involved in transactional work" ${ }^{462}$ ), India currently enjoys a "rapidly expanding 'inhouse counsel' sector., ${ }^{, 63}$

This confluence of factors makes India an ideal context in which to examine the likelihood of Nelson and Nielsen's entrepreneurial lawyer taking hold over the emerging nation's burgeoning IHL sector. Will the context mirror the American experience? Current evidence suggests it will. India is undergoing a "commoditization of the [legal] profession." 464 Further mirroring the American experience, a "newly emerging corporate legal elite threatens the "essential' nature of the Indian legal profession," entrepreneurializing what was otherwise a "noble heritage." extent that this characterization is accurate, the Indian legal profession may soon suffer from the initial stages of what currently ails certain American companies, making our prescriptions timely.

Herein lies the slippery professional slope that this Article identifies and seeks to remedy retrospectively in the American context, contemporaneously in the U.K. context, and prospectively in the Swedish and Indian contexts. Too often lawyers, including general counsel, blithely identify the significant potential gains offered by the entrepreneurial lawyer, while failing to acknowledge its prohibitively expensive moral hazards. By the time lawyers and their clients recognize the associated costs, often irreparable damage has already occurred. An awareness of the American legal experience, its problems, and our corresponding prescriptions provides an antidote.

growing-major-economy/ [perma.cc/4S4T-YLEU].

460. John Flood, The Re-landscaping of the Legal Profession: Large Law Firms and Professional Re-regulation, 59 CURRENT SOC. 507, 519 (2011).

461. Id.

462. Jayanth K. Krishnan, Outsourcing and the Globalizing Legal Profession, 48 WM. \& MARY L. REV. 2189, 2238 (2007).

463. Papa \& Wilkins, supra note 458.

464. Id. at 203 .

465. Id. at 177,182 . 


\section{CONCLUSION}

The role of general counsel in the corporate context currently sits at an evolutionary crossroads; the function can either continue embracing the negative entrepreneurial tendencies that, left unchecked, jeopardize the firms general counsel serve, or it can aspire to the higher professional standard of the lawyer-statesman ideal. This Article advocates the latter option through its prescriptions of legal astuteness and strategic astuteness, which taken together, provide the necessary antidote to the role's current ailment.

Business managers and their counsel can be more effective drivers of both compliant corporate behavior and the creation of sustainable value with integrity when they work together as strategic partners - that is, when legally astute managers and strategically astute lawyers form heavyweight teams. ${ }^{466}$ Legislative efforts, such as the Foreign Corrupt Practices Act, SOX, Dodd-Frank, and the Consumer Product Safety Improvement Act, have proved inadequate to prevent undue risk-taking and outright illegality. Counsel need to more actively promote legal and ethical compliance, but so do their corporate clients. Law, ethics, and compliance are just too important to be left to the lawyers, so managers must be legally astute and insist on lawyers who are strategically astute. Unfortunately, many managers leave business school ill-equipped to manage the legal and ethical aspects of business. Many lawyers lack the business expertise necessary to be true partners in value creation. Law schools can help fill that gap, just as business schools can promote ethics, legal literacy, and the exercise of informed judgment.

Counsel who work hand-in-hand with managers to create realizable value, marshal resources, and manage risk (both business and legal) must guard against being coopted by their manager colleagues. But so must their clients. Each individual in the firm has a role to play. We agree with former Texaco CEO James Kinnear's statement that "[f]ish rots from the head." "667 Both lawyers and managers are more likely to be influenced by what their leaders actually do, whom they hire and promote, whom and how they compensate, criticize or praise, than by their exhortations. Are whistle blowers punished and shunned or praised for their courage? Are employees who cheat on their expense report sanctioned even if they are top sales reps?

The evolving role of in-house counsel outside the United States poses a risk that counsel will fall prey to the ethical pitfalls of Nelson and

466. Clark \& Wheelwright, supra note 226.

467. B AGLEY, supra note 71, at 201. 
Nielsen's American entrepreneurial lawyer. We submit that the prescriptions we present in this Article can help firms both in the United States and abroad and their managers and lawyers guard against the destruction of value that occurs when companies fail to practice strategic compliance management and violate societal expectations. They will also reduce the likelihood of "[n]ew forms of regulation or effective enforcement ... without regard for feasibility or cost."

468. Christensen, supra note 201, at 461. Accordingly, "government regulation is not a good substitute for knowledgeable self-restraint." Id. 